
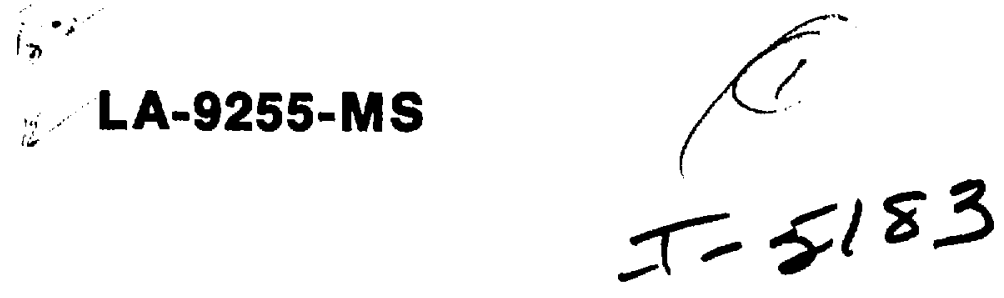

Los Alamos National Laboratory is operated by the University of Californla for the United States Department of Energy under contract W-7405-ENG-36.

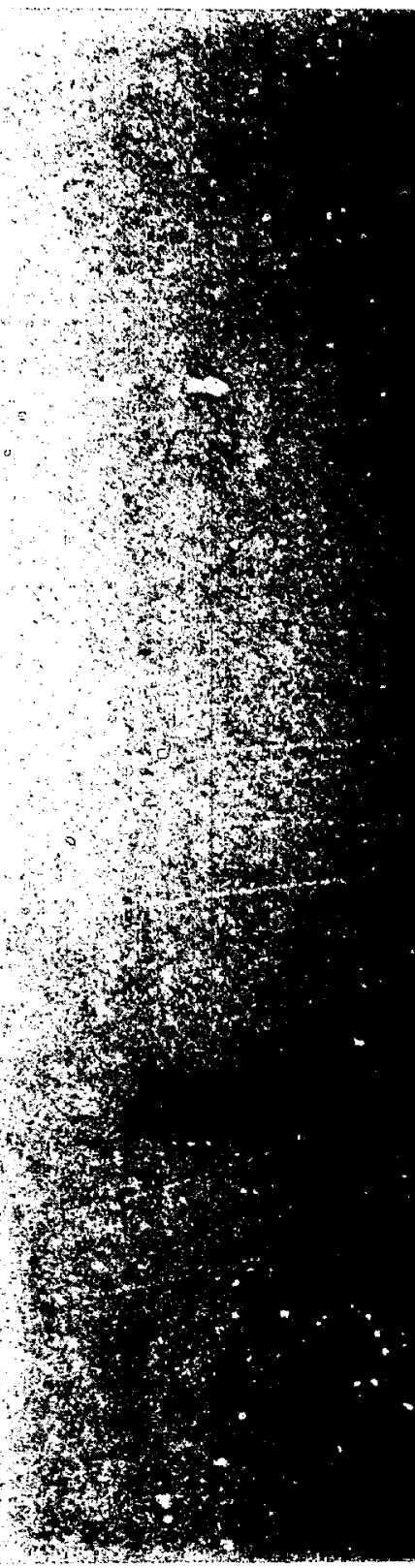


This work was supported by the US Department of Energy, Nevada Nuclear Waste Storage Investigations.

Edited by Glenda Ponder, ESS Division

\section{DISCLAIMER}

This repurt was prepared as an account of work sponsored by an agency of the United States Government. Neither the United States Government nor any agency thereof, nor any of their employees, makes any warranty, express or implied, or assumes any legal liability or responsibility for the accuracy, completeness, or usetulness of any information, apparatus, product, or process disclosed, or represents that its use would not infringe privately owned rights. References herein to any specific commercial product, process, or service by trade name, trademark, manufact urer, or otherwise, does not necescarily constitute or imply its endirirsement, recommendation, or favoring by the United States Government or any agency thereof. The virws and opirions of authors expressed herein do not necessarily state or reflect those of the United Siates Govermment or any agency thereof. 


\title{
Petrologic Studies of Drill Cores USW-G2 and UE25b-1H, Yucca Mountain, Nevada
}

\author{
F. Caporuscio \\ D. Vaniman \\ D. Bish \\ D. Broxton \\ B. Arney \\ G. Heiken \\ F. Byers \\ R. Gooley \\ E. Semarge
}

This report was prepered wa an account of work sponsored by en wency of the United Stumes Government. Neither the United States Government nor any agency thereot, nat any of their Emeloyeer, makes any wartanty, express of implied, or assumes any legal liability of rebonsibility for the eccuracy. camerests

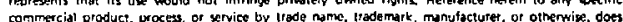
not necessarily constitute or imoly ils endersement. recommendation, of lavering by the Unitod 


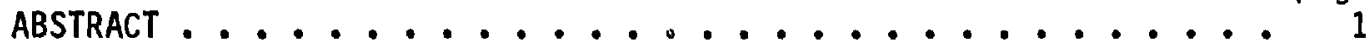

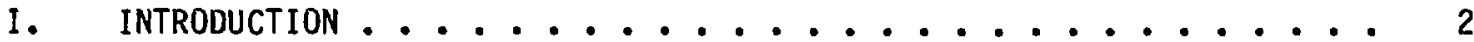

II. METHODS ......................... 6

A. X-ray Powder Diffraction Analyses .......... 6

B. Oxidation States of Fe-Ti Oxides .............. 10

C. Electron Microprobe Analysis of Glasses and Minerals . . . . 17

D. Scanning Electron Microscope Studies . . . . . . . . 18

III. PETROGRAPHIC DESCRIPTION OF DRILL HOLE USH-G2 . . . . . . . . 18

A. Tiva Canyon Member of Paintbrush Tuff . . . . . . . . 18

B. Yucca Mountain Member of Paintbrush Tuff ............ 18

C. "Bedded" Tuff Between Yucca Mountain and Pah Canyon Members of

the Paintbrush Tuff ............... 20

D. Pah Canyon Member of the Paintbrush Tuff ........... 21

1. Upper and Lower Vitric Zone ............... 22

2. Middle Zone of Moderate Welding . . . . . . . . . . 22

E. Pumiceous Unit Between Pah Canyon and Topopah Spring . . . . . 24

F. Topopah Spring Member of the Paintbrush Tuff and Underlying Bedded Tuff .................. 24

1. First Interval ...................... 25

2. Second Interval ................. 26

3. Third Interval ................... 27

4. Fourth Interval .................. 30

5. Fifth Interval .................... 31

6. Bedded Tuff ...................... 31

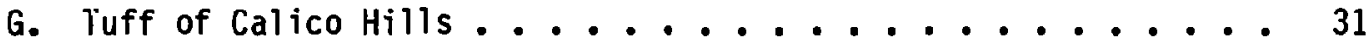

H. Prow Pass Member of the Crater Flat Tuff ........... 34

I. Bullfrog Membei of the Crater Flat Tuff ............ 37

J. Tram Member of the Crater Flat Tuff and Underlying Bedded Tuff . 38

1. Tram Member at Depths of 3574 to $3914 \mathrm{ft}$. . . . . . . . 3!

2. Bedded Tuff at Depths of 3914 to $3982 \mathrm{ft}$........ $4 i$

3. Air-fall Tuff Located at a Depth of 3982 to $4079 \mathrm{ft}$. . . 40

K. Hornblende-Biotite Rhyodacite Lava ............... 41

L. Bedded Tuff above the Lithic Ridge Tuff . . . . . . . . . . 42

M. Lithic Ridge Tuff ..................... 43

N. Bedded Tuff and Ash Flow at the Base of the Lithic Ridge Tuff .45

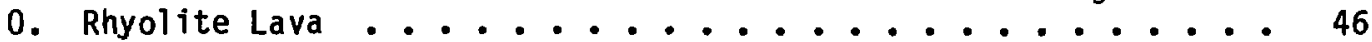

P. Quartz Latite Lava .................. 47

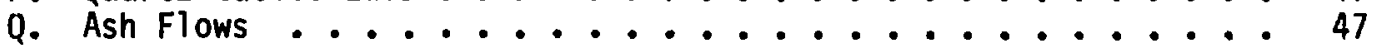

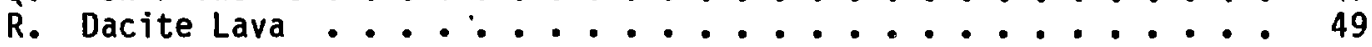

S. Baked Conglomerate and Reworked Tuff ............. 49

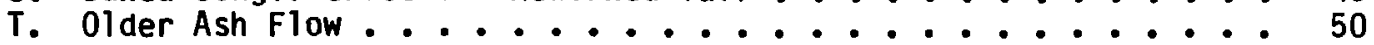

IV. PETROGRAPHIC DESCRIPTION OF DRILL HOLE UE25b-1H, FROM 2400 TO

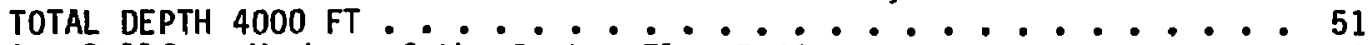

A. Bullfrog Member of the Crater Flat Tuff .......... 51

B. Tram Member of the Crater Flat Tuff ............ 54

1. Upper Tram Subunit .................... 54

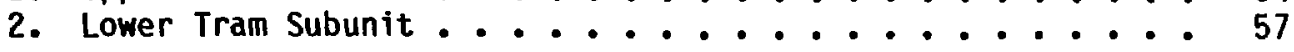


C. Bedded Tuff Between the Tram Menber of the Crater Flat Tuff and the Lithic Ridge Tuffs ............... 59

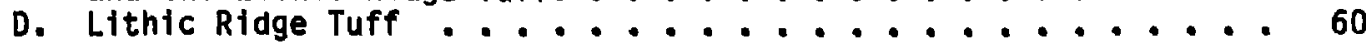

V. SUMMARY: COMPARISON OF USW-G2 AND UE25b-1H AND RELATIONS TO OTHER

DRILL HOLES AT YUCCA MOUNTAIN .............. 60

A. Upper Members of Pafntbrush Tuff : . . . . . . 61

B. Topopah Spring Member of Paintbrush Tuff . . . . . . 61

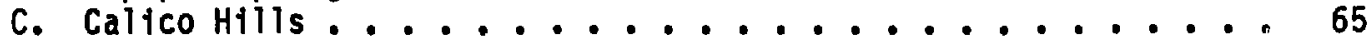

D. Prow Pass Member of Crater Flat Tuff . . . . . . . . 67

E. Bullfrog Member of Crater Flat Tuff ........... 67

F. Tram Member of Crater Flat Tuff ............. 68

G. Lithic Ridge Tuff ................ 68

H. Dacite, Rhyolite, and Quartz Latite Lava Flows in USH-G2 . . . 69

VI. CONCLUSIONS .............................. 70

A. The Effective Use of Sorptive Zeolites for Repository Siting . 70

B. Clay Mineralogy as a Guide to High-Temperature Alteration

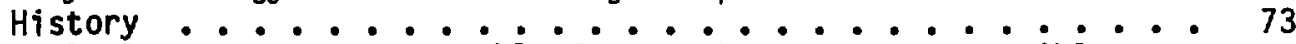

C. Geologic Units Most Favorable for Further Study as Possible Waste Repository Horizons ............. 74

ACKNOWLEDGMENTS ................................ 75

REFERENCES ............................. 75

APPENDIX A . . . . . . . . . . . . . . . . . . . 78

GLASS, ZEOLITE, AND CLAY ANALYSES FROM DRILL HOLES USW-G2 AND

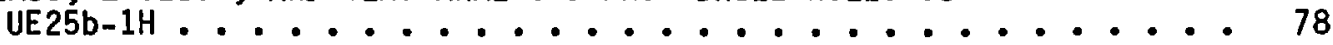

TABLE A-I GLASS ANALYSES FROM THE UPPER PAINTBRUSH TUFF, DRILL HOLE USW-G2 ....................... 78

TABLE A-II ZEOLITE ANALYSES FROM DRILL HOLE USW-G2 . . . . 79

TABLE A-III ZEOLITE ANALYSES FROM DRILL HOLE UE25B-1H . . . . 93

TABLE A-IV CLAY ANALYSES FROM DRILL HOLE USW-G2 ........ 94

TABLE $V$ CLAY ANALYSES FROM DRILL HOLE UE25B-1H . . . . . 104

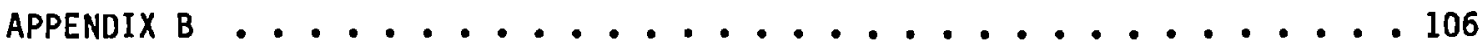

SCANIING ELECTRON MICROSCOPY OF AUTHIGENIC PHASES . . . . . 106 
PETROLOGIC STUDIES OF DRILL CORES USW-G2 AND UE25b-1H,

YUCCA MOUNTAIN, NEVADA

by

F. Caporuscio, D. Vaniman, D. Bish, D. Broxton, B. Arney, G. Heiken,

F. Byers, R. Gooley, and E. Semarge

\section{ABSTRACT}

The tuffs of the Nevada Test Site are currently under investigation as a possible deep geologic site for high-level radioactive waste disposal. This report characterizes tuff retrieved in core from two drill holes, USW-G2 and UE25b-1H, at the Yucca Mountain block. The USW-G2 drill core is from the northernmost extent of the block, whereas UE25b-1H is adjacent to an earlier drill hole, UE25a-1. The drill cores USW-G2 and UE25b-1H bottomed at 6000 and $4200 \mathrm{ft}$, respectively. Petrographic and $x$-ray diffraction studies of the two drill cores are presented in this report and indicate that tuffs (composed primarily of variably welded ash flows) are partially recrystallized to secondary minerals. Correlations of stratigraphy are also made with previous drill cores from Yucca Mountain.

The Topopah Spring Member of the Paintbrush Tuff is very similar to horizons of this unit encountered in other drill holes. It has a thick densely welded zone, bounded above and below by vitrophyres, and a zeolitized horizon at the bottom. For the first time (in USW-G2), there is a zeolitized horizon observed at the top of the Topopah Spring Member. There is also a set of open (and possibly recent) fractures found in the Topopah Spring Member that will require future studies. The Tuffs of Calico Hills, below the Topopah Spring Member, are extremely thick in the USW-G2 core and heavily zeolitized with subequal proportions of clinoptilolite and mordenite. If downward percolation is the major water transport method in the unsaturated zone of Yucca Mountain then these two units combined may offer considerable potential for a radioactive waste repository site. A repository in the Topopah Spring Member would benefit from high surrounding thermal conductivity and an underlying radionuclide barrier. Alternatively, waste might be buried within the Tuffs of Calico Hills which are relatively impermeable and contain abundant sorptive zeolites.

The three other potential repository horizons encountered in USW-G2 and UE25b-1H are the Bullfrog and Tram Members of the Crater Flat Tuff and the Lithic Ridge Tuff. Some negative characteristics of these three units include significant lateral variations in thickness, degree of welding, and secondary mineralogy. Also there is hydrothermal mineralization (especially fluorite, barite, and sulfides) in the lower three potential horizons. Despite these negative characteristics, the thick Lithic Ridge Tuff may have thermal and mechanical properties favorable for a repository. This thick unit, however, has highly variable secondary mineralization and its thermal-mechanical properties are still 
unknown. Also encountered in the lower part of USW-G2 is a thick sequence of lavas ( $900 \mathrm{ft}$ ) that have no correlative counterparts.

Hew questions are raised by these most recent core studies. First, is there an increase in hydrothermal mineralization at depth? Resource conflicts could arise if there were an underlying ore deposit. Second, what is the genesis of the open fractures in the Topopah Spring unit? Third, what are the ages of deeply percolating fluids that lead to calcite-filled fractures deep in the core? Fourth, the paragenesis of the zeolite phases must be unraveled. Are they produced in an open system, in a closed system, or an intricate balance of both? However, the study of these sorptive minerals is useful only if we understand the transport directions of water at Yucca Mountain. We must know and understand both present hydrology and paleohydrology before we can effectively utilize horizons bearing the sorptive minerals, zeolites, and clays.

\section{INTRODUCTION}

The southwestern portion of the Nevada Test Site (NTS) in south-central Nevada is currently under investigation to determine the suitability of the area for an underground high-level waste repository. This report is a continuation of studies, sponsored by the Nevada Nuclear Waste Storage Investigations (NNWSI), concerned with the tuff units of Yucca Mountain and with the suitability of these units for waste isolation. The exploration drill holes described in this report (USW-G2 and UE25b-1H) are located on or near Yucca Mountain near the southwest border of the NTS (Fig. 1). The Yucca Mountain block is composed of a thick sequence of ash-flow tuffs, lavas, and bedded tuffs that are derived primarily from the Timber Mountain-0asis Valley cauldron complex (Byers et al. 1976; Christiansen et al. 1977). The thickness of tuffs at Yucca Mountain exceeds $6000 \mathrm{ft}$ and may extend to $10000 \mathrm{ft}$. The tuffs range in age from 15 to $12 \mathrm{Myr}$.

Previous work at Yucca Mountain performed by the Los Alamos National Laboratory includes the mineralogic and petrologic characterization of core from three other drill holes. The first was J-13 (Heiken and Bevier 1979) nacated in Fortymile Wash on the eastern edge of Yucca Mountain (Fig. 1). Next, Sykes et al. (1979) determined the mineralogy and petrology of core from driTR mole UE25a-1 and discussed the significance of the major zeolite phase, cTimoptitalite. The third site, USW-G1, was characterized by Bish et al. (IgfI)- This arill hole reached a depth of $6000 \mathrm{ft}$ and greatly enhanced our knowlectge of both the stratigraphy and the secondary mineralogy of the tuffs 




Fig. 1 .

Location map of Yucca Mountain, on the southwest boundary of the Nevada Test Site. The locations of drill holes J-13, UE25a-1, UE25b-1H, USW-G1, USW-G2, and USW-G3 are indicated. Note the outline of the exploration block for the NNWSI program. From Topopah Spring NW quadrangle (Christiansen and Lipman 1965). 
of Yucca Mountain. Supplementary reports by Bish (1981) and Carroll et al. (1981) presented further studies of core from specific horizons in the USW-G1 and UE25a-1 drill holes. This report will focus on studies of two arill holes, USW-G2 and UE25b-1H. The USW-G2 drill hole is located on the northern edge of Yucca Mountain and was sited in an attempt to intersect a major western bounding fault at depth and to explore the tuff stratigraphy at the north end of the block. The location of UE25b-1H is $100 \mathrm{~m}$ north of UE25a-1 and helped to extend the depth of the tuff stratigraphy found in the latter hole. The USW-G2 core bottomed at $6000 \mathrm{ft}$, whereas UE25b-1H bottomed at 4000 ft.

Tuff is a complex rock type that varies greatly in mineralogy, texture, and chemical composition. The tuffs from USW-G2 and UE25b-1H show only limited variations in bulk chemistry, and their physical variations are controlled principally by their mode of emplacement (air-fall and ash-flow mechanisms) and by post-emplacement alteration processes. Some alterations that occur during cooling are welding, which produces significant variations in density and porosity of ash-flow tuff; primary devitrification, which causes subsolidus breakdown of glass to cristobalite and alkali feldspar; and the precipitation of vapor-phase minerals during degassing of the ash-flow deposits. Secondary alteration products, primarily clays, silica phases, zeolites, and authigenic feldspars, are formed by alteration of glass through interaction with ground water long after emplacement and consolidation of tuff. These reactions may be enhanced by the slight rise in temperature due to burial.

Preliminary macroscopic descriptions of tuff units in each drill hole were provided by Maldonado and Koether (report in preparation) and R. Spengler [U.S. Geological Society (USGS), personal communication]. The objective of this report is to use the lithologic logs of Maldonado as a framework (Fig. 2) to present the primary and secondary mineralogy in specific samples obtained from the USW-G2 and UE25b-1H drill cores. The major work performed on the samples consisted of transmitted and reflected light microscopy, coupled with $x$-ray diffraction and microprobe analyses of phenocrysts and secondary phases. of primary importance is the paragenesis of devitrification products of silicic volcanic glasses. Devitrification involves both those phases formed during the cooling history of the rocks immediately after emplacenient, and those occurring much lazer during diagenetic alteration that took place either above 


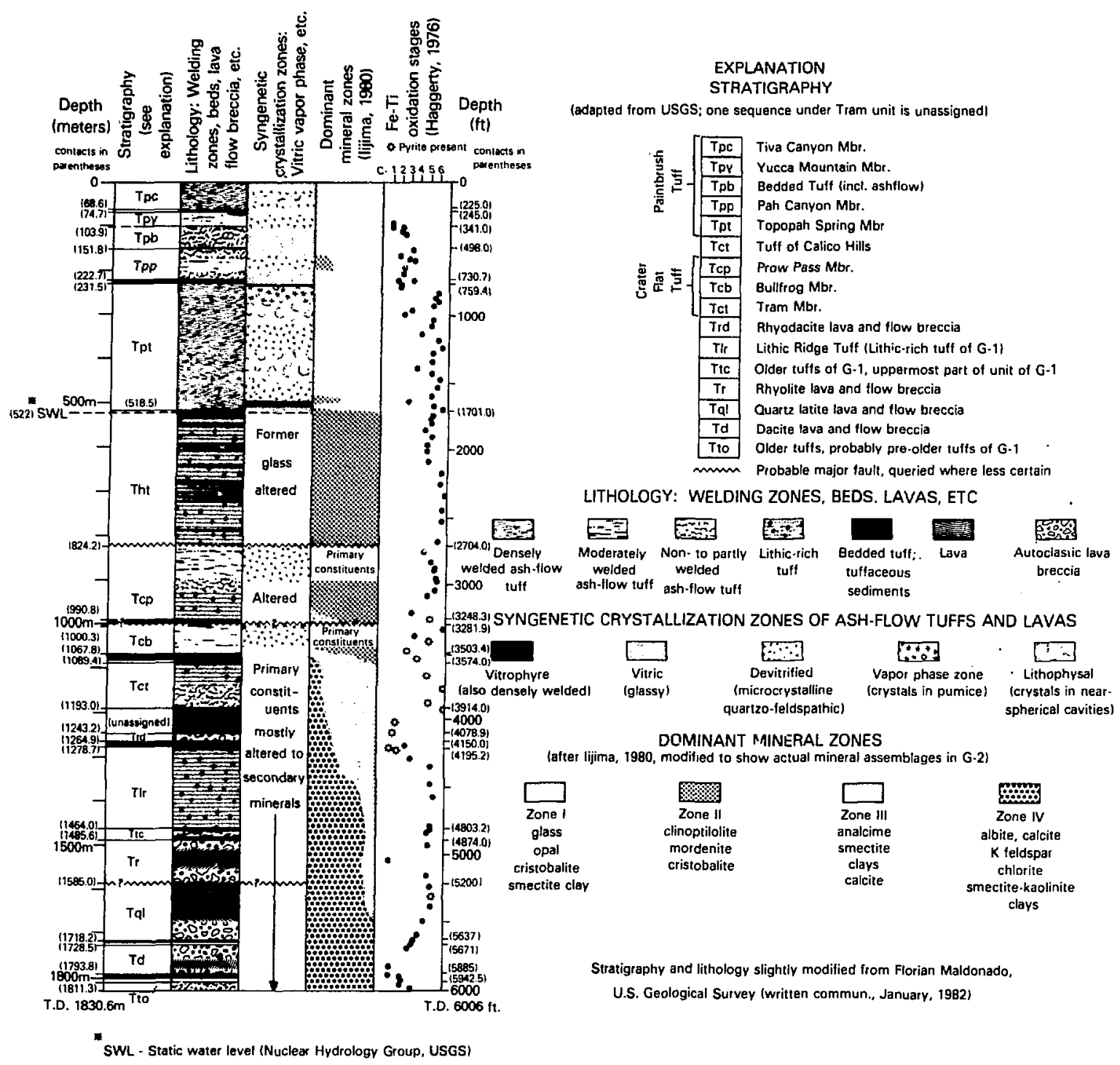

Fig. 2.

Stratigraphy of primary and secondary petrographic features in drill hole USW-G2. 
or below the water table. Zeolite phases received particular attention as natural barriers to radionuclide migration, as indicators of tuff alteration, and as guides to paleotemperatures and paleohydrology. Special emphasis was also placed on clay minerals because of their ubiquitous occurrence, their swelling properties, and their usefulness as indicators of alteration temperatures. Oxidation states of $\mathrm{Fe}-\mathrm{Ti}$ opaque oxides have been determined as possible indicators of the highest ambient $\mathrm{fO}_{2}$ of the silicic tuffs and to determine their reduction capabilities on ground water in the present system. Phenocrysts were analyzed as possible stratigraphic markers and to delineate the petrogenesis of individual ash-flow tuffs. The data generated are also useful in constructing stratigraphic correlations to ash flows of the other drill cores. These stratigraphic correlations can be used to identify the limitations of possible repository horizons. Detailed petrographic descriptions and phenocryst analyses will be compiled in a later report covering USW-G2 and UE25b-1H. Analyses of glasses, zeolites, and clays are presented in Appendix $A$, in keeping with our emphasis on authigenic mineralization.

\section{METHODS}

A. X-ray Powder Diffraction Analyses

For routine $x$-ray analysis, a large amount of core was crushed to obtain representative samples. Between 15 and $20 \mathrm{~g}$ of sample were removed from the cores, and ground in a shatterbox to approximately 50-100 mesh $(0.15$ to 0.3 $\mathrm{mm}$ ). A portion of this powder was ground under acetone in a mortar and pestle to approximately -300 mesh $(50 \mu \mathrm{m})$. The -300 mesh powder was mounted in glass in cavities large enough for the sample area to fully contain the $x$-ray beam at the lowest angle of interest. This technique ensured that clay mineral contents in the bulk samples would not be underestimated. Unused ground samples were stored in plastic vials for future reference and study.

All diffraction patterns were obtained with a Siemens D-500 powder diffractometer using a Cu-target $x$-ray tube and a diffracted-beam monochromator. The diffractometer was commonly run between $2^{\circ}$ and $32^{\circ} 2 \theta$ at a scanning rate of $1^{\circ}$ per minute, and the patterns were recorded on a stripchart recorder. Examples of $x$-ray diffraction patterns are shown in Fig. 3.

Mineral identification was accomplished by comparison of observed patterns to standard patterns produced by this $x$-ray diffraction system and by comparison to standards from the Joint Committee on Powder Diffraction 

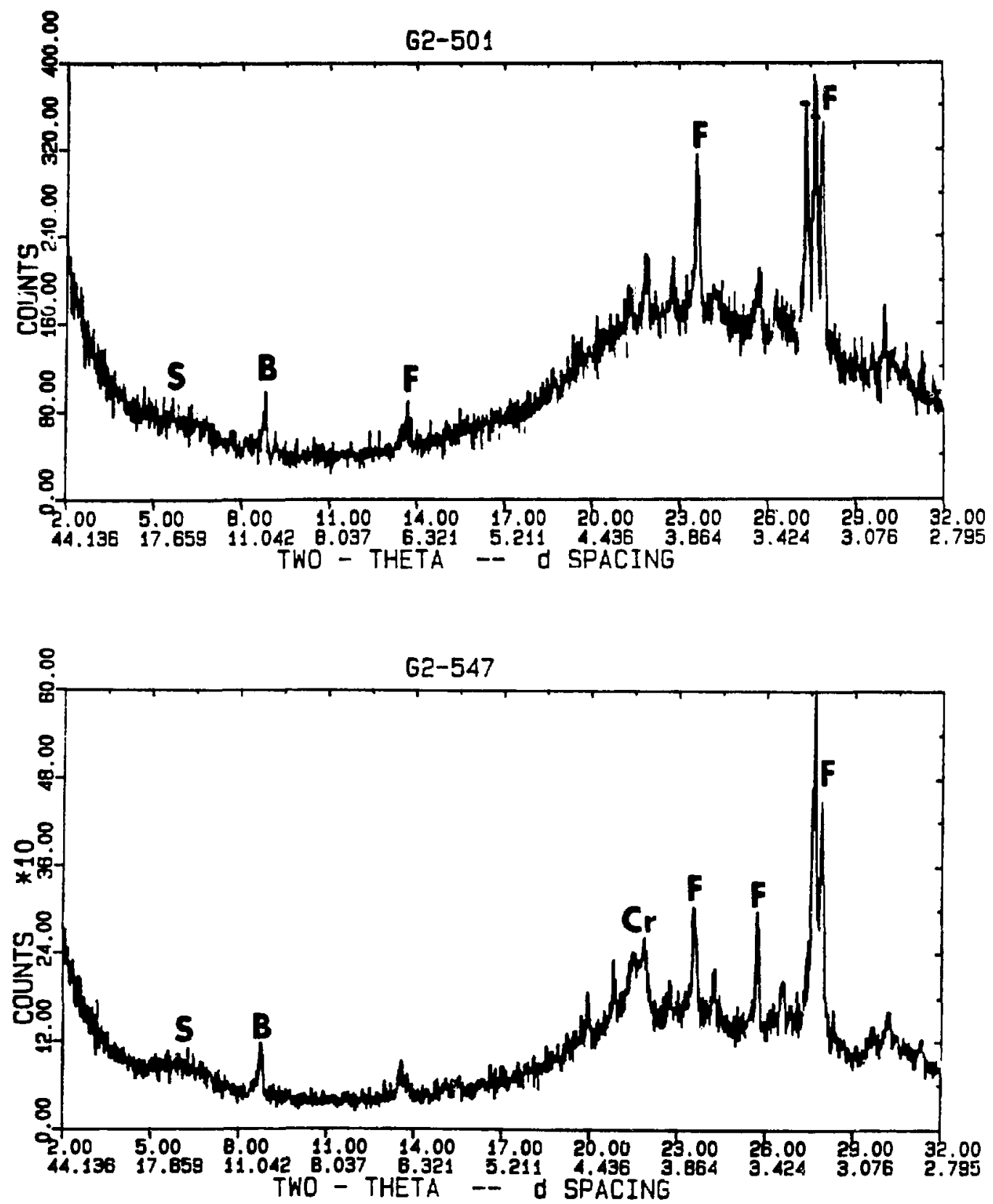

Fig. 3.

Representative $x$-ray diffraction patterns from the USW-G2 drill hole. Labels denote several characteristic peaks of smectite (S), quartz (Q), alkali feldspar (F), cristobalite $(C r)$, clinoptilolite $(C)$, mordenite $(M)$, and biotite mica (B). 

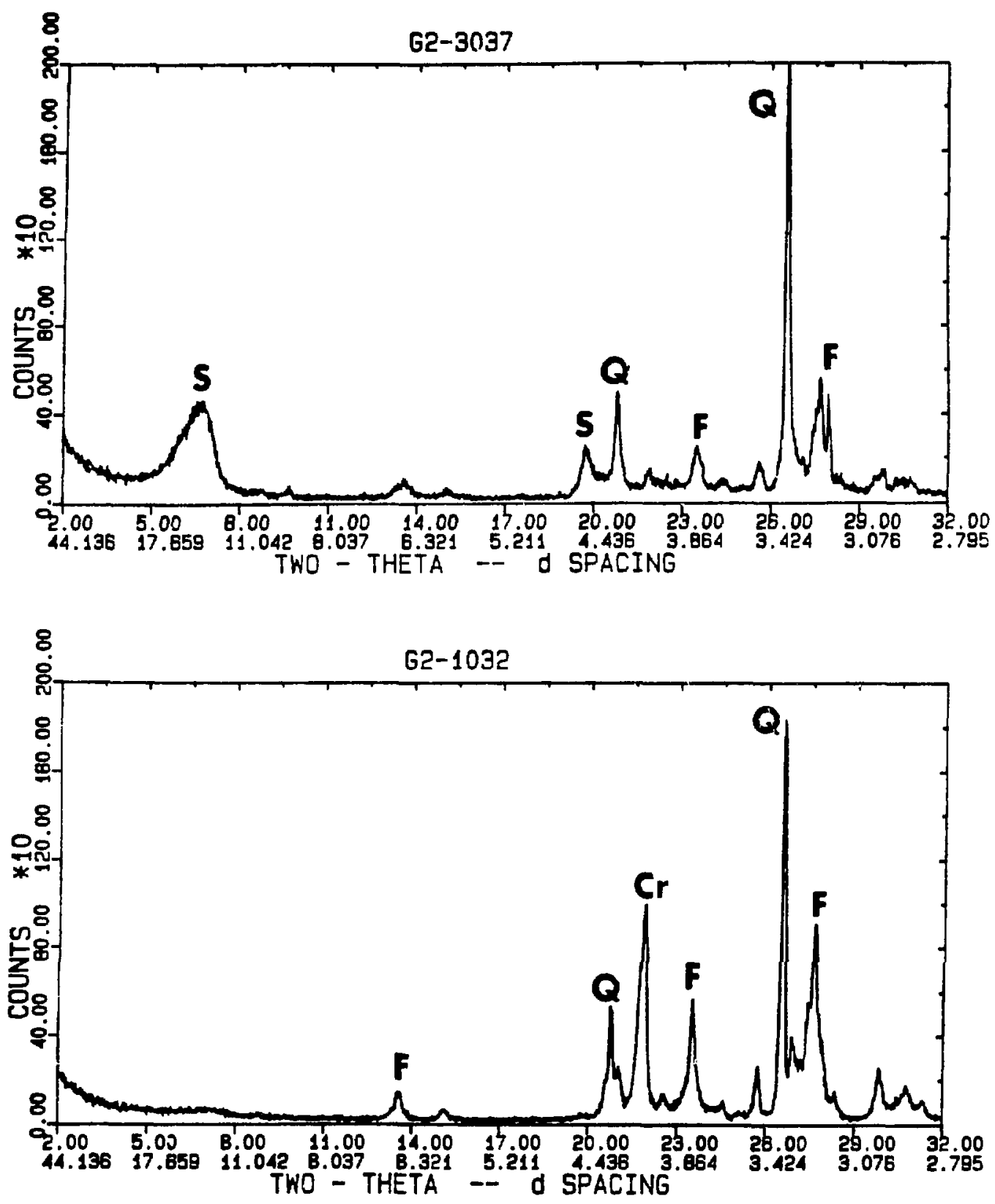

Fig. 3. (cont.) 

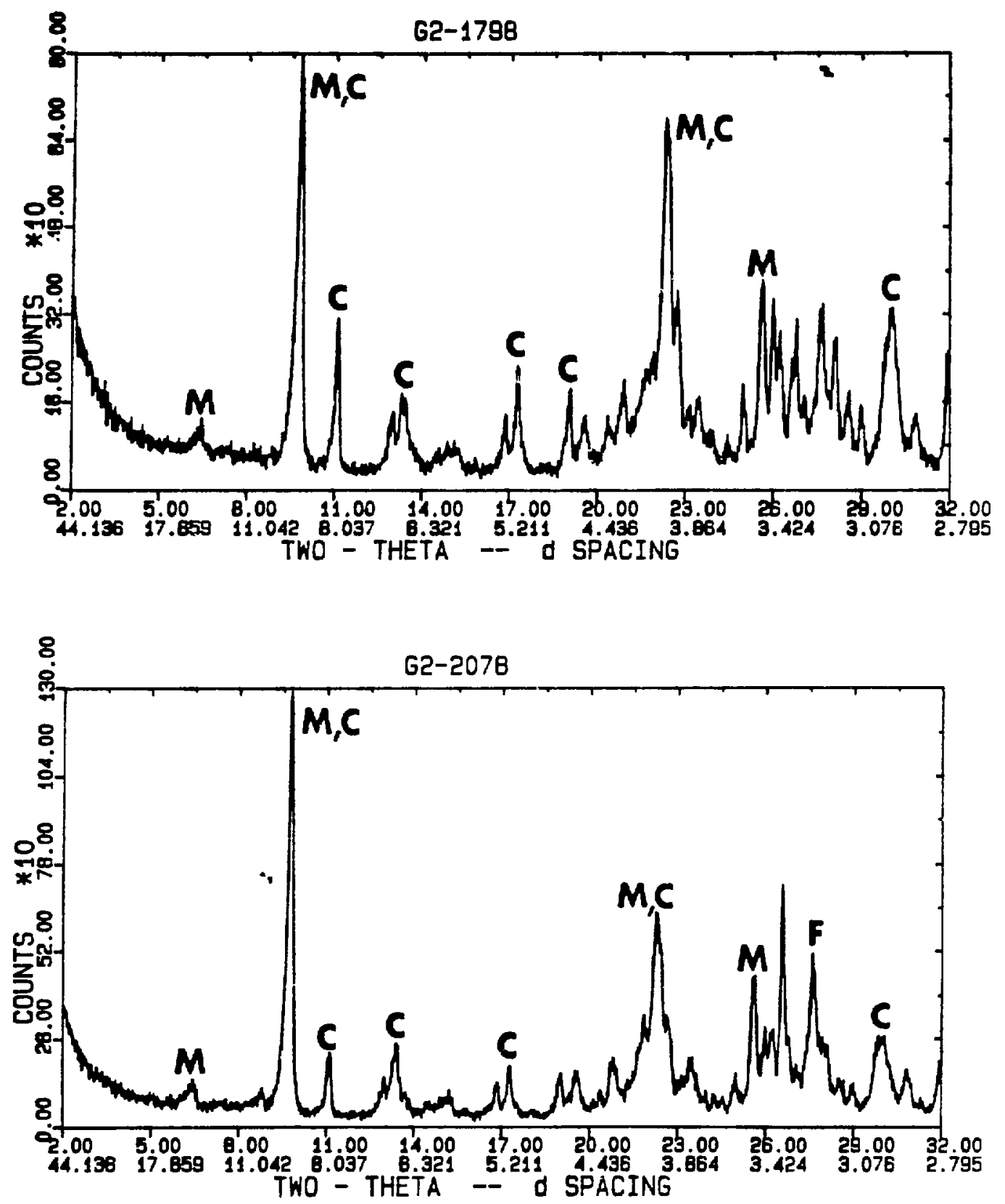

Fig. 3. (cont.) 
Standards (JCPDS). JCPDS standard numbers and characteristic peaks of minerals found in Yucca Mountain tuffs are recorded in Bish et al. (1981). Estimation of concentrations of the various minerals present was accomplished through comparison to in-lab standard patterns of known mixtures. As in Bish et al. (1981), several assumptions are implicit in concentration estimates, incluaing the assumed lack of significant preferred orientation and the assumed lack of appreciable variations in intensity with compositional changes. When samples are ground to less than -300 mesh, orientation effects are minimized, and repeated diffractometer scans reveal that orientation effects, if present, are fairly constant. We do not assume that all minerals have similar total scattering, even when they have approximately the same average atomic number. Absolute intensities obtained from calculated powder patterns allow us to determine the intensity variations from mineral to mineral and demonstrate that all minerals in the tuffs do not scatter similarly. For example, a given amount of quartz scatters much more strongly than the same amount of heulandite or analcime, i.e., the detection limits for quartz are lower than they are for the zeolites. Calculated powder patterns also show that moderate variations in composition have only minor effects on the absolute intensities in diffraction patterns. Because of the large number of minerals present in each sample, the concentrations presented in Tables $I$ and II have sizeable uncertainties, and as in Bish et al. (1981), the concentrations are intended for qualititative comparisons only.

Ciay mineral separations were performed for severa? core samples throughout the drill hole lengths. Separations require an initial dispersion of crushed samples in 600 to $1000 \mathrm{ml}$ of distilled water in an ultrasonic bath. The large size fraction was sedimented out, and a finer fraction was concentrated in a Sorvall SS-3 centrifuge. Oriented sample mounts were prepared of this fine fraction material by dropping an aqueous suspension onto glass slides and allowing it to dry. These mounts were then used to determine the type of clay minerals present using the techniques described in Bish et al. (1981).

B. Oxidation States of Fe-Ti Oxides

Ubiquitous Fe-Ti oxides are observed as microphenocrysts and as alteration products in the ash flows and lavas. Morphologies indicate that both cubic [magnetite-ülvospinel solid solution series (Mt-Usp $\left.{ }_{s s}\right)$ ] and rhombohedral 
TABLE I

$X$-RAY DIFFRACTION ANALYSES OF TUFF FROM DRILL HOLE USW-G2 (WEIGHT PERCENT)

\begin{tabular}{|c|c|c|c|c|c|c|c|c|c|c|c|}
\hline Sample & $\begin{array}{c}\text { Depth } \\
\text { (II) }\end{array}$ & $\begin{array}{l}\text { Simec- } \\
\text { tfte }\end{array}$ & Mitea & $\begin{array}{l}\text { Clino- } \\
\text { ptilolite }\end{array}$ & $\begin{array}{l}\text { Morden- } \\
\text { ite }\end{array}$ & $\begin{array}{l}\text { Anal- } \\
\text { clme }\end{array}$ & Quartz & $\begin{array}{l}\text { Cristo- } \\
\text { balite }\end{array}$ & $\begin{array}{c}\text { Alkali } \\
\text { Feldspar }\end{array}$ & Calcite & Other \\
\hline \multicolumn{12}{|l|}{ USW- } \\
\hline G2-10 & 3.0 & & $5-10$ & & & & & $30-50$ & $30-50$ & & $10-20^{b}$ \\
\hline G2-100 & 30.5 & & $<5$ & & & & & $30-50$ & $30-50$ & & $10-25^{b}$ \\
\hline G2-200 & 61.0 & & & & & & & $30-50$ & $30-50$ & & $5-15^{b}$ \\
\hline G2-230 & 70.1 & & & & & & & $30-50$ & $30-50$ & & $5-15^{b}$ \\
\hline G2-270 & 82.3 & $2-10$ & & & & & & $30-50$ & $30-50$ & $15-30$ & \\
\hline G2-304 & 92.7 & & & & & & $5-10$ & $30-50$ & $30-50$ & & $10.20^{b}$ \\
\hline G2-331 & 100.9 & $30-50$ & & & & & & & $30-50$ & $10-20$ & \\
\hline G2-339 & 103.0 & $40-60$ & & & & & & & $5-10$ & & $30-50^{C}$ \\
\hline G2-358 & 109.1 & $15-30$ & & & & & Tr. & $5-10$ & $20-40$ & & $20-40^{C}$ \\
\hline G2-395 & 120.4 & 5-15 & $<2$ & & & & $<5$ & $10-20$ & $15-30$ & & $30-50^{C}$ \\
\hline G2-501 & 152.7 & $5-20$ & $<3$ & & & & & $5-10$ & $10-20$ & & $40-60^{C}$ \\
\hline G2-547 & 266.7 & $5-15$ & $<5$ & & & & & $5-15$ & $10-20$ & & $40-60^{C}$ \\
\hline GR-548 & 167.0 & & $<5$ & $5-10$ & & & & $20-40$ & $30-50$ & & \\
\hline$G 2-561$ & 171.0 & $10-20$ & $<3$ & $10-20$ & & & & $20-40$ & $25-40$ & & \\
\hline G2-627 & 191.1 & $5-15$ & $<5$ & $10-20$ & & & & $20-40$ & $30-50$ & & \\
\hline $62-675$ & 205.7 & $30-50$ & $<5$ & $15-30$ & & & & $5-10$ & $15-30$ & & \\
\hline G2-723 & 220.4 & 5-15 & $<5$ & & & & & $<5$ & $5-10$ & $30-50$ & $15-30^{c}$ \\
\hline $62-743$ & 226.5 & $30-50$ & $<5$ & $<5$ & & & $5-15$ & $5-15$ & $10-20$ & $5-15$ & $15-30^{c}$ \\
\hline G2-762 & 232.3 & $2-5$ & & $75-90$ & & & & $5-15$ & $<5$ & & $10-20^{b}$ \\
\hline $62-770$ & 234.7 & $<2$ & $5-10$ & & & & & $15-30$ & $60-80$ & & \\
\hline G2-822 & 250.5 & $5-10$ & $<5$ & & & & & 20.40 & $30-50$ & & $10-20^{b}$ \\
\hline G2-85j & 260.6 & $<5$ & $2-5$ & & & & & $20-40$ & $30-50$ & & $5-15^{b}$ \\
\hline G2-898 & 273.7 & $<2$ & $2-5$ & $<5$ & & & & $20=40$ & $40-60$ & & $5-10^{b}$ \\
\hline G2-921 & 280.7 & $10-20$ & & & & & $20-40$ & $15-30$ & $20-40$ & $5-10$ & \\
\hline G2-951 & 289.9 & $<2$ & & & & & $15-30$ & $20-40$ & $20-40$ & & \\
\hline G2-984 & 299.9 & $2-10$ & & & & & $15-30$ & $10-20$ & $15-30$ & $15-30$ & \\
\hline G2-1032 & 314.6 & $2-10$ & $<2$ & & & & $15-30$ & $20-40$ & $20-40$ & & \\
\hline G2-1072 & 326.7 & $2-10$ & $<2$ & & & & $20-40$ & 5-15 & $30-50$ & & \\
\hline $62-1133$ & 345.3 & $5-15$ & $<2$ & & & & $15-30$ & $20-40$ & $40-60$ & & \\
\hline $62-1178$ & 359.1 & $<5$ & $<2$ & & & & $10-25$ & $20-40$ & $30-50$ & & \\
\hline G2-1234 & 376.1 & $2-10$ & & & & & $10-25$ & $20-40$ & $30-50$ & & \\
\hline $62-1281$ & 390.4 & 5- 15 & & & & & $15-30$ & $15-30$ & $30-50$ & & \\
\hline$G 2-1331$ & 405.7 & $5-15$ & & & & & $15-30$ & $20-40$ & $30-50$ & & \\
\hline G2-1382 & 421.2 & $5-15$ & $<2$ & & & & $15-30$ & $15-30$ & $40-60$ & & \\
\hline G2-1420 & 432.8 & $5-15$ & & & & & $15-30$ & $20-40$ & $30-50$ & & \\
\hline G2-1461 & 445.3 & 5-15 & & & & & $10-20$ & $30-50$ & $30-50$ & & \\
\hline G2-1536 & 468.2 & $10-20$ & & $<5$ & & & $10-20$ & $30-50$ & $30-50$ & & \\
\hline G2-1585 & 483.1 & $5-15$ & & $<5$ & & & $10-25$ & $20-40$ & $30-50$ & & \\
\hline G2-1634 & 498.0 & $30-50$ & «2 & $30-50$ & & & & $15-30$ & & & \\
\hline G2-1664 & 507.2 & $<2$ & & $<2$ & & & $5-10$ & 5-10 & $10-20$ & & $50-70^{C}$ \\
\hline G2-1691 & 515.4 & $5-15$ & & $40-60$ & $5-10$ & & & $15-25$ & $5-15$ & & \\
\hline G2-1745 & 531.9 & $10-20$ & & $30-50$ & $5-10$ & & $5-10$ & $15=30$ & $10-20$ & & \\
\hline G2-1752 & 534.0 & 5-15 & & $50-70$ & $5-10$ & & $<5$ & 5-15 & $5-10$ & & \\
\hline G2-1798 & 548.0 & $<2$ & & $40-60$ & $15-30$ & & $5-15$ & $10-20$ & $15-30$ & & \\
\hline$G 2-184 B$ & 563.3 & & & $40-60$ & $15-30$ & & Tr. & $15-30$ & $10-20$ & & \\
\hline G2-1899 & 578.8 & $<2$ & $<2$ & $40-60$ & $15-30$ & & $5-10$ & $10-20$ & $10-20$ & & \\
\hline G2-1952 & 595.0 & & $<5$ & $5-10$ & $40-60$ & & $10-20$ & $10-20$ & $10-20$ & & \\
\hline G2-2001 & 609.9 & & $<2$ & $5-10$ & $40-60$ & & $10-20$ & $10-20$ & $15-30$ & & : \\
\hline G2-2078 & 633.4 & $<5$ & $<5$ & $20-40$ & $20-40$ & & $5-10$ & $10-20$ & $10-20$ & & \\
\hline
\end{tabular}


TABLE I (cont.)

\begin{tabular}{|c|c|c|c|c|c|c|c|c|c|c|c|}
\hline Sample & $\begin{array}{l}\text { Depth } \\
\text { (m) }\end{array}$ & $\begin{array}{l}\text { Simes- } \\
\text { tite }\end{array}$ & Mica & $\begin{array}{l}\text { Clino- } \\
\text { ptilolite }\end{array}$ & $\begin{array}{l}\text { Morden- } \\
\text { ite }\end{array}$ & $\begin{array}{l}\text { Anel- } \\
\text { cime }\end{array}$ & quartz & $\begin{array}{l}\text { Cristo- } \\
\text { balite }\end{array}$ & $\begin{array}{c}\text { Alkali } \\
\text { Feldspar }\end{array}$ & Calcite & Other \\
\hline $62-2158$ & 657.8 & $<5$ & $<5$ & $20-40$ & $15-30$ & Tr. & 5.10 & $15-30$ & $10-20$ & & \\
\hline G2-2248 & 685.2 & $<5$ & $<2$ & $20-40$ & $20-40$ & & $5-15$ & $15-30$ & $15-30$ & & \\
\hline G2-2353 & 717.2 & $<2$ & $2-10$ & $5-15$ & $20-40$ & & $15-30$ & $15-30$ & $10-20$ & & \\
\hline$G 2-2430$ & 740.7 & $<5$ & $5-15$ & $20-40$ & $5-15$ & & $20-40$ & $0-10$ & $20-40$ & & \\
\hline G2-2528 & 770.5 & $<5$ & $5-15$ & $<5$ & $15-30$ & & $20-40$ & $<5$ & $20-40$ & & \\
\hline G2-2667 & 812.9 & $<5$ & $5-10$ & & $20-40$ & & $15-30$ & $<5$ & $30-50$ & & \\
\hline G2-2744 & 836.4 & $<5$ & $<2$ & & & & $30-50$ & $5-10$ & $40-60$ & & \\
\hline G2-2820 & 859.5 & $\ll 2$ & $<2$ & & & & $20-40$ & $2-10$ & $50-70$ & & \\
\hline G2-2869 & 874.5 & $<2$ & $2-5$ & & & & $20-40$ & $2-5$ & $50-70$ & & \\
\hline G2-2887 & 880.0 & $<5$ & $<2$ & & & & $20-40$ & $2-5$ & $50-70$ & & \\
\hline G2-2950 & 899.2 & $2-10$ & $<3$ & & & & $20-40$ & $2-10$ & $40-60$ & & \\
\hline G2-2970 & 905.3 & $5-15$ & $<3$ & & & & $30-50$ & $0-10$ & $40-60$ & & \\
\hline
\end{tabular}

TABLE I (cont.)

\begin{tabular}{|c|c|c|c|c|c|c|c|c|c|c|c|}
\hline Sample & $\begin{array}{l}\text { Depth } \\
\text { (m) }\end{array}$ & $\begin{array}{l}\text { Smec- } \\
\text { tite }\end{array}$ & Mica & $\begin{array}{l}\text { Clina- } \\
\text { ptilolite }\end{array}$ & $\begin{array}{l}\text { Morden- } \\
\text { ite }\end{array}$ & $\begin{array}{l}\text { Anal - } \\
\text { cime }\end{array}$ & Quartz & $\begin{array}{l}\text { Cristo- } \\
\text { balite }\end{array}$ & $\begin{array}{l}\text { Alkali } \\
\text { Feldspar }\end{array}$ & Calcite & Other \\
\hline G2-3037 & 925.7 & $30-50$ & $<2$ & & $<5$ & & $20-40$ & $0-5$ & $15-30$ & & \\
\hline G2-3067 & 934.8 & & $<2$ & $5-10$ & $20-40$ & & & $20-40$ & $20-40$ & & \\
\hline G2-31 92 & 972.9 & $5-10$ & & $20-40$ & $5-15$ & Tr. & $20-40$ & $0-5$ & $20-40$ & & \\
\hline G2-3250 & 990.6 & $15-30$ & $<2$ & $5-15$ & $5-15$ & $20-40$ & $15-30$ & $0-5$ & $15-30$ & & \\
\hline G2-3308 & 1008.3 & $2-5$ & $10-20$ & & & & $15-30$ & $0-10$ & $40-60$ & & \\
\hline G2-3330 & 1015.0 & & $2-10$ & & & & $20-40$ & $0-10$ & $50-70$ & & \\
\hline${ }^{a_{G 2-3330}}(\mathrm{~F})$ & 1015.0 & $5-15$ & $2-10$ & & & & $10-20$ & & $15-30$ & & $40-60^{d}$ \\
\hline G2-3349 & 1020.8 & $<2$ & $2-10$ & & & & $15-30$ & $0-10$ & $50-70$ & & \\
\hline G2-3366 & 1026.0 & $<2$ & $2-10$ & & & & $20-40$ & 0.10 & $50-70$ & & \\
\hline G2-3416 & 1041.2 & $<2$ & $2-10$ & & & & $20-40$ & & $50-70$ & & \\
\hline G2-3454 & 1052.8 & $20-35$ & $<5$ & & $15-30$ & Tr. & $15-35$ & & $15-35$ & & \\
\hline G2-3492 & 1064.4 & $10-25$ & $<5$ & & $15-30$ & $5-10$ & $20-40$ & & $15-30$ & & \\
\hline G2-3512 & 1070.5 & $10-20$ & $5-10$ & & $2-10$ & $10-20$ & $20-40$ & & $30-50$ & & $<5^{e}$ \\
\hline G2-3541 & 1079.3 & $5-15$ & $5-10$ & & & $20-40$ & $20-40$ & & $15-30$ & & $<5^{e}$ \\
\hline G2-3578 & 1090.6 & $15-30$ & $5-15$ & & $15-30$ & & $20-40$ & & $15-30$ & & \\
\hline G2-3627 & 1105.5 & $10-20$ & $5-15$ & & & $<5$ & $20-40$ & & $30-50$ & & \\
\hline $62-3671$ & 1118.9 & $5-15$ & $5-10$ & & & $5-10$ & $20-40$ & & $30-50$ & $5-10$ & $<2^{e}$ \\
\hline G2-3720 & 1133.9 & $5-15$ & $5-10$ & & & $\mathrm{Tr}$ & $20-40$ & & $30-50$ & & \\
\hline G2-3724 & 1135.1 & $20-30$ & $<5$ & & & & $30-50$ & & $20-40$ & & $<5^{b}$ \\
\hline G2-3750 & 1143.0 & $20-30$ & $5-15$ & & & & $20-40$ & & $30-50$ & & \\
\hline G2-3772 & 1149.7 & $15-30$ & $5-10$ & & & & $20-40$ & & $30-50$ & & \\
\hline G2-3795 & 1156.7 & $25-40$ & & & & $<2$ & $30-50$ & & $20-40$ & & $<5^{e}$ \\
\hline G2-3833 & 1168.3 & $20-40$ & $2-10$ & & & & $20-40$ & & $20-40$ & & \\
\hline G2-3875 & 1181.1 & $20-30$ & $5-10$ & & & $<5$ & $30-50$ & & $15-30$ & & \\
\hline G2-3908 & 1191.2 & $10-25$ & & & & & $20-40$ & & $30-50$ & $2-10$ & \\
\hline $62-3933$ & 1198.8 & $10-20$ & & & & $20-40$ & $20-40$ & & $20-40$ & $5-10$ & \\
\hline $62-3968$ & 1209.4 & $10-25$ & $2-10$ & & & Tr. & $30-50$ & & $30-50$ & & $\operatorname{Tr} .^{e}$ \\
\hline $62-4005$ & 1220.7 & $10-20$ & $5-15$ & & & $<5$ & $15-30$ & & $30-50$ & $5-10$ & \\
\hline $62-4090$ & 1246.6 & $15-30$ & $10-25$ & & & $2-10$ & $15-30$ & & $20-40$ & $5-15$ & \\
\hline $62-4167$ & 1270.1 & $10-20$ & $10-20$ & & & $<2$ & $15-30$ & & $30-50$ & $5-15$ & $<5^{e}$ \\
\hline $62-4199$ & 1279.9 & $10-20$ & $5-15$ & & & $\mathrm{Tr}$ & $10-25$ & & $30-50$ & $10-25$ & $<2^{*}$ \\
\hline $62-4209$ & 1282.9 & $5-15$ & $5-10$ & & & $2-10$ & $10-25$ & & $40-60$ & $:<5$ & \\
\hline $32-4267$ & 1300.6 & $10-20$ & $5-10$ & & & $<5$ & $20-40$ & & $30-50$ & $<5$ & \\
\hline $2-4329$ & 1319.5 & $5-15$ & $2-10$ & & & $<5$ & $20-40$ & & $30-50$ & $5-15$ & \\
\hline
\end{tabular}


TABLE I (cont.)

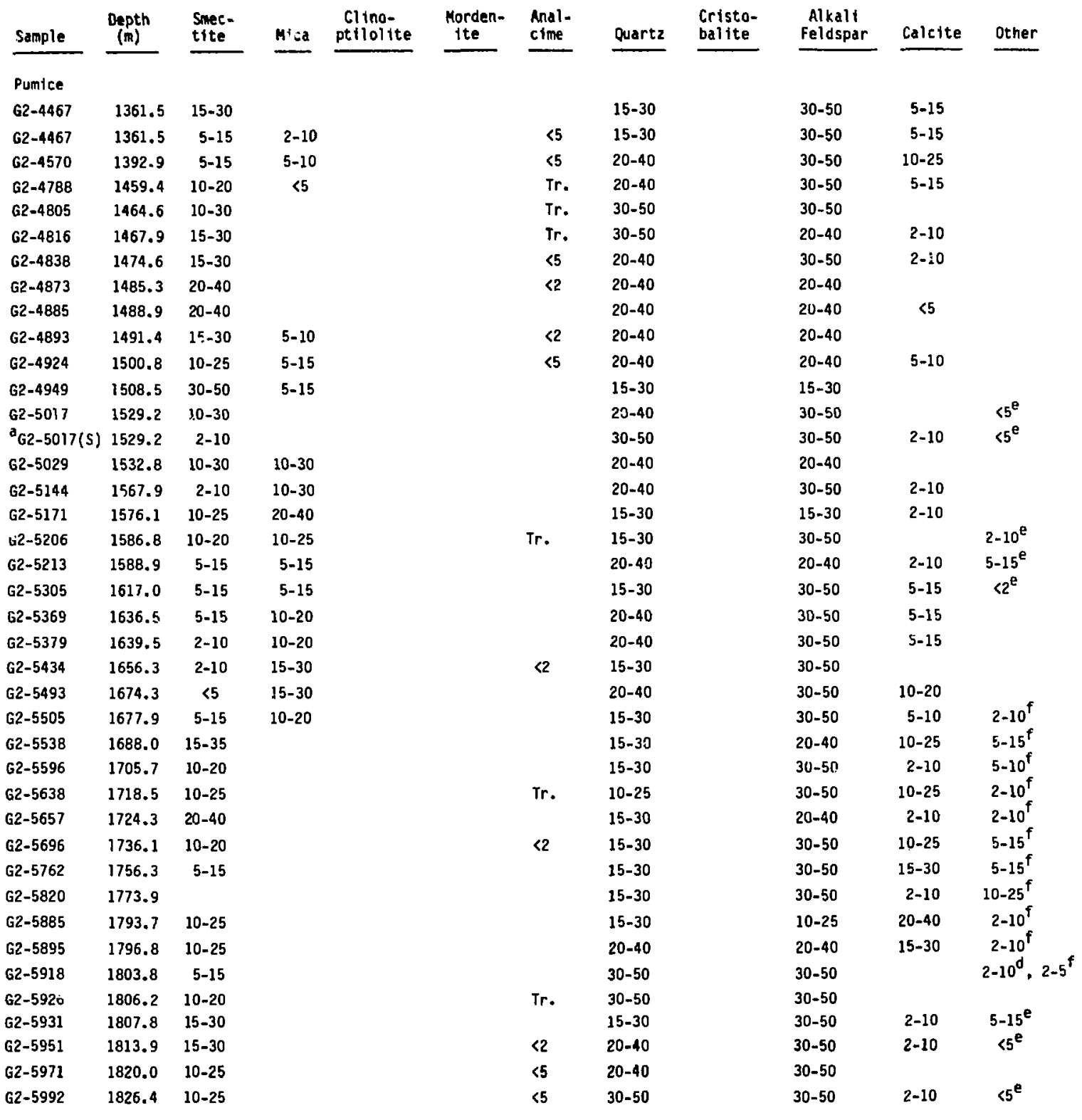

\footnotetext{
$F=$ Fracture; $5=$ Spherulite

b Tridymite

c Glass

Hematite

e Kaolinite

f Chlorite
} 
TABLE II

X-RAY DIFFRACTION ANALYSES OF TUFF FROM DRILL HOLE UE25b-1H (WEIGHT PERCENT)

\begin{tabular}{|c|c|c|c|c|c|c|c|c|c|c|c|c|}
\hline Somple & $\begin{array}{l}\text { Depth } \\
\text { (II) }\end{array}$ & $\begin{array}{l}\text { Simec- } \\
\text { tite }\end{array}$ & Mica & $\begin{array}{l}\text { clino- } \\
\text { ptilolite }\end{array}$ & $\begin{array}{l}\text { Morden- } \\
\text { Ite }\end{array}$ & $\begin{array}{l}\text { Anai:- } \\
\text { ctwe }\end{array}$ & Quartz & $\begin{array}{l}\text { Alkali } \\
\text { Feldspar }\end{array}$ & Calcite & Kaolinite & & Dther \\
\hline \multicolumn{13}{|l|}{ UE25D- } \\
\hline$\overline{1 H 2402}$ & 732.1 & $10-20$ & $2-10$ & & & & $30-50$ & $30-50$ & & & & \\
\hline 1H 2450 & 746.8 & $5-15$ & $5-10$ & & & & $30-50$ & $30-50$ & $2-10$ & & & \\
\hline $1 H 2525$ & 769.6 & $5-15$ & $5-15$ & & & & $30-50$ & $30-50$ & & & & \\
\hline 2H 2596 & 791.3 & $5-15$ & $2-10$ & & & & $30-50$ & $30-50$ & $2-10$ & & & \\
\hline IH 2651 & 808.0 & $5-15$ & $2-10$ & & & & $30-50$ & $30-50$ & & & & \\
\hline 1H 2737 & 834.2 & $2-5$ & $2-10$ & & & & $20-40$ & $40-60$ & & & & \\
\hline $1 H \quad 2832$ & 863.2 & $10-20$ & $2-10$ & $2-5$ & $10-25$ & & $15=30$ & $20-40$ & $2-5$ & & & \\
\hline 1H 2855 & 870.2 & $10-25$ & $2-5$ & $2-5$ & $10-25$ & & $15-30$ & $20-40$ & $2-10$ & & & \\
\hline IH 2867 & 873.9 & $10-25$ & $2-10$ & & $2-5$ & & $20-40$ & $40-60$ & & & & \\
\hline 1H 2879 & 877.5 & $15-30$ & $10-20$ & $5-15$ & $5-15$ & & $20-40$ & $20-40$ & $2-10$ & & & \\
\hline 1H 2919 & 889.7 & & $5-15$ & & $20-40$ & & $15-30$ & $20-40$ & & & & \\
\hline 1H 2946 & 897.9 & $2-10$ & $2-10$ & & & & $30-50$ & $30-50$ & $2-10$ & & & \\
\hline 1H 2953 & 900.1 & $2-10$ & $2-10$ & & & & $30-50$ & $30-50$ & $2-10$ & & & \\
\hline IH 2988 & 910.7 & $5-15$ & $5-15$ & $\mathrm{Tr}$. & & & $30-50$ & $30-50$ & $2-5$ & & & \\
\hline IH 3050 & 929.6 & $5-15$ & $5-15$ & $2-5$ & & & $20-40$ & $40-60$ & $2-10$ & & & \\
\hline IH 3092 & 942.4 & $2-10$ & $5-10$ & Tr. & & & $40-60$ & $30-50$ & $2-5$ & & & \\
\hline$a_{1 H} 3092(F)$ & 942.4 & & $2-10$ & & & & $30-50$ & $20-40$ & $15-30$ & & & \\
\hline 1H 3095 & 943.4 & $<5$ & $5-15$ & & & & $30-50$ & $40-60$ & & & & \\
\hline $2 H 3098$ & 944.3 & $5-15$ & $5-15$ & & & & $20-40$ & $40-60$ & $2-5$ & & & \\
\hline $1 H \quad 3128$ & 953.4 & $5-15$ & $5-15$ & & & & $20-40$ & $40-60$ & $2-5$ & & & \\
\hline$a_{1 H} 3128(t)$ & 953.4 & $2-5$ & $2-5$ & & & & $20-40$ & $20-40$ & $15-30$ & & & \\
\hline IH 3163 & 964.1 & $2-5$ & $5-15$ & & & & $20-40$ & $40-60$ & $2-5$ & & & \\
\hline$a_{1 H} 3163(f)$ & 964.1 & & $2-5$ & & & & $10-30$ & $10-30$ & $50-70$ & & & \\
\hline IK 3185 & $9 ? 0.8$ & $10-25$ & $10-20$ & & & & $20-40$ & $30-50$ & & & & \\
\hline$a_{1 h} 3185(f)$ & 970.8 & $<5$ & $<5$ & & & & $5-15$ & & $60-80$ & & $2-10^{b}$, & $10-30$ \\
\hline 1H 3196 & 974.1 & $2-10$ & $5-15$ & & & & $20-40$ & $40-60$ & & & & \\
\hline $1 \mathrm{H} 3222$ & 982.1 & $2-5$ & $5-15$ & & & & $20-40$ & $50-70$ & & & & \\
\hline 1H 3225 & 983.0 & $5-15$ & $5-15$ & & & & $20-40$ & $40-60$ & & & & \\
\hline $1 H 3257$ & 992.7 & $30-50$ & $5-15$ & & & & $10-30$ & $20-40$ & & & & \\
\hline $1 H 3267$ & 995.8 & $15-30$ & $2-10$ & & & & $30-50$ & $20-40$ & & & & \\
\hline IH 3298 & 1005.2 & $5-15$ & $2-10$ & & & $T r$. & $20-40$ & $40-60$ & & & & \\
\hline 1H 3326 & 1013.8 & $5-15$ & $5-15$ & & & $2-5$ & $20-40$ & $40-60$ & & & & \\
\hline 1H 3362 & 1024.7 & $10-25$ & $5-15$ & & & $2-5$ & $20-40$ & $30-50$ & & $T r$. & & \\
\hline 2H 3374 & 1028.4 & 5-15 & $5-15$ & & & $10-30$ & $20-40$ & $20-40$ & & $<2$ & & \\
\hline 2H 3393 & 1034.2 & $5-15$ & $5-10$ & & & $10-30$ & $20-40$ & $20-40$ & $5-15$ & $2-5$ & & \\
\hline 2H 3401 & 1036.6 & $2-5$ & $2-10$ & & & $10-30$ & $20-40$ & $20-40$ & $2-5$ & $2-5$ & & \\
\hline 1H 3459 & 1054.3 & $5-15$ & $5-15$ & & & $10-30$ & $20-40$ & $15-30$ & $2-10$ & $2-10$ & & \\
\hline 143459 & 3057.4 & $5-15$ & $5-15$ & & & $10 \mathrm{~m} 30$ & $20-40$ & $20-40$ & $2-10$ & $2-10$ & & \\
\hline $1 H 3506$ & 1068.6 & $10-25$ & $5-15$ & & & $10-30$ & $20-40$ & $20-40$ & $2-10$ & $2-10$ & & \\
\hline $1 H 3530$ & 1075.9 & $10-20$ & $5-10$ & & & $15-30$ & $20-40$ & $30-50$ & $<5$ & $\cdot<2$ & & \\
\hline${ }_{1 H} 3530(F)$ & 1075.9 & $10-20$ & & & & $5-15$ & $20-40$ & $20-40$ & & $5-10$ & & \\
\hline IH 3548 & 1081.4 & $5-15$ & $5-15$ & & & $2-5$ & $20-40$ & $30-50$ & $2-10$ & $2-5$ & & \\
\hline $1 H 3548$ (I) & 1081.4 & $10-20$ & $5-15$ & & & & $15-30$ & $30-50$ & $10-20$ & $<2$ & & \\
\hline IH 3571 & 1088.4 & $5-10$ & $2-10$ & & & $2-5$ & $30-50$ & $15-30$ & $20-40$ & $<5$ & & \\
\hline 143572 & 1088.7 & $2-10$ & $2-10$ & & & $<2$ & $20-40$ & $30-50$ & $15-30$ & $<2$ & & \\
\hline${ }^{1 H} 3572(I)$ & 1088.7 & $10-25$ & $5-15$ & & & & $20-40$ & $20-40$ & $5-15$ & $<2$ & & \\
\hline IH 3602 & 1097.9 & $5-15$ & $2-10$ & & & $10-30$ & $20-40$ & $20-40$ & $5-15$ & $<2$ & & \\
\hline${ }^{a} 1 H 3602$ (F) & 1097.9 & $<5$ & & & & $5-15$ & $2-10$ & & $30-50$ & & : & $30-50^{b}$ \\
\hline $1 H 3660$ & 1115.6 & $5-15$ & $2-10$ & & & $15-30$ & $20-40$ & $20-40$ & $2-10$ & $2-5$ & & \\
\hline
\end{tabular}




\section{TABLE II (cont.)}

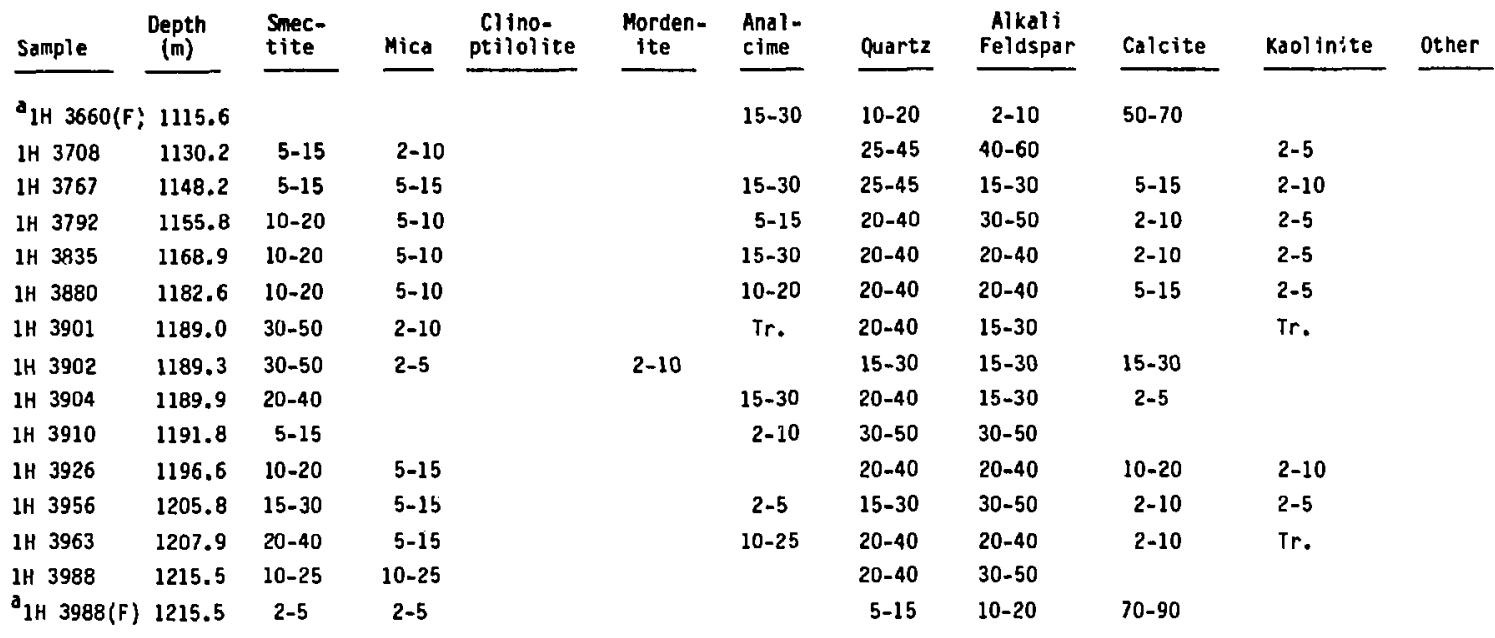

\footnotetext{
$F=$ Fracture; $I=$ Inclusion

b Fluorite

c Todorokite
} 
[1]menite-hematite solid solution series (IIm-Hem $s$ )] phases are present. Subsequent oxidation of the $\mathrm{Fe}-\mathrm{Ti}$ oxides after eruption produced a series of oxidation exsolution phases in the original grains. Haggerty (1976) devised a series of empirical oxidation exsolution stages for both the cubic $\left(C_{1}\right.$ to $\left.C_{7}\right)$ and rhombohedral $\left(R_{1}\right.$ to $\left.R_{7}\right)$ phases, where 1 denotes unoxidized and 7 denotes complete oxidation. That classification is used in this report to identify the relative maximum oxidation state of the samples (Table III). In all cases, the oxidation state of the Ilm-Hem ss closely parallels that of the

\section{TABLE III}

EXSOLUTION OXIDATION OF Fe-Ti OXIDE CUBIC AND RHOMBOHEDRAL PHASES ${ }^{a}$

\section{Cubic}

$c_{1}$ magnetite

$C_{2}$ magnetite (+ ilmenite)

$\mathrm{C}_{3} \quad$ ilmenite + magnatite

$\mathrm{C}_{4}$ mottled ilmenite + magnetite + rutile + hematite + pleonaste (meta-ilmenite)

$\mathrm{C}_{5}$ rutile + titanohematite

$C_{6} \underset{\text { (+ pseudobrookite) }}{\text { rutile }+ \text { titanohematite } R_{6}}$

C7 pseudobrookite + (titanohematite + rutile) Rhombohedral
$\mathrm{R}_{1} \quad$ ilmenite
$R_{2}$ ilmenite + rutile
$R_{3}$ rutile + ilmenite
$R_{4} \begin{aligned} & \text { rutile + titanohematite }+ \\ & \text { ferrian rutile + ferrian ilmenite }\end{aligned}$
$R_{5}$ rutile + titanohematite
$R_{6} \underset{\text { rutile + titanohematite (+ pseudo- }}{\text { brookite }}$
$R_{7} \begin{aligned} & \text { pseudobrookite }+ \text { (rutile + titano- } \\ & \text { hematite) }\end{aligned}$

a Haggerty 1976 
Mt-ïsp ss . Therefore, all oxides reported are given a $C_{x}$ notation for consistency. The oxidation state of the Fe-Ti oxides is dependent on the highest ambient $\mathrm{fO}_{2}$, which may often be correlated to the permeability and degree of welding of the tuffs. In nonwelded tuffs (high permeability), the Fe-Ti oxides are generally oxidized $\left(c_{5}-c_{7}\right)$. Densely welded tuffs (low permeability) tend to record low oxidation states $\left(C_{1}-C_{3}\right)$. Due to the kinetics of oxidation exsolution, the retrograde process is extremely sluggish. Therefore, the oxidation state recorded is the highest level obtained and not always indicative of the present oxygen fugacity in the tuffs.

Major exceptions to the scheme described above occur in rocks containing sulfides, carbonates, or vapor-phase alteration. For example, in the densely welded portion of the Topopah Spring Member where vapor phase is present, the oxidation state varies greatly. The reason for this is that vapor-phase fluids have high water contents and therefore have a high oxygen fugacity. oxidation state is controlled by vapor-phase fluids that may or may not intersect a particular grain. In many samples, oxide grains in close proximity can have radically different oxidation states. In rocks containing sulfides or carbonates, oxygen fugacity is decreased and the oxidation of the Fe-Ti oxide minerals is retarded. Either of these fluids ( $S$ - or $\mathrm{CO}_{2}$ bearing) would have a much lower $\mathrm{fO}_{2}$ than one bearing water only. Therefore these fluids may oxidize the Fe-Ti oxides, but to a lesser extent. Clear examples can be observed in the sulfide bearing rocks of both USW-G2 and Ue25b-1H at 3416 to $4209 \mathrm{ft}$ (1041 to $1283 \mathrm{~m}$ ) and at 3394 to $3988 \mathrm{ft}(1034$ to $1216 \mathrm{~m})$, respectively. Excellent examples of carbonate solutions restricting the oxidation of Fe-Ti oxides can be seen from 5493 to $5992 \mathrm{ft}(1674$ to $1826 \mathrm{~m})$ in the USW-G2 drill core.

C. Electron Microprobe Analysis of Glasses and Minerals

Mineral and glass compositions were determined on an automated Cameca electron microprobe with accelerating potential fixed at $15 \mathrm{kV}$ and sample current at $0.015 \mu \mathrm{A}$ on thorium oxide. Analyses were made at either $10 \mathrm{~s}$ or 30000 counts for each element. Composicions were calculated from corrected peak intensities using the methods of Bence and Albee (1968). Data for glasses, clays, and open-channel sorptive zeolites are listed in the Appendix $A$, Tables $A-I$ to $A-V$. Analyses of primary phenocrysts will be tabulated in $a$ later data report. 
D. Scanning Electron Microscope Studies

Imaging and qualitative composition studies were made on an ISI model DS-130 scanning electron microscope, operated at variab?e keV (up to $40 \mathrm{keV}$ ). Semiquantitative and qualitative analyses from primary $x$-ray signals weri obtained on a Kevex model 7000 energy-dispersive system with the electron besm operating at $15 \mathrm{keV}$. Back-scattered and secondary-electron images are described in this report.

\section{PETROGRAPHIC DESCRIPTION OF DRILL HOLE USW-G2}

A. Tiva Canyon Member of Paintbrush Tuff $(0$ to $245 \mathrm{ft}, 0$ to $74.7 \mathrm{~m})$

The Tiva Canyon Member of the Paintbrush Tuff was not cored during the drilling of USW-G2. Sample chips are available with approximate depth notations; these samples were analyzed by $x$-ray diffraction, with the results summarized in Fig. 4 and Table I. No further petrographic characterization of the Tiva Canyon Member was attempted. Descriptions of the Tiva Canyon sample chips from USW-G2 are available in Maldonado and Koether (in preparation). B. Yucca Mourtain Member of Paintbrush Tuff (245 to $341 \mathrm{ft}, 74.7$ to $104.0 \mathrm{~m})$

The Yucca Mountain Member of the Paintbrush Tuff consists of a basal, reworked, bedded tuff (2.5 ft or $0.8 \mathrm{~m}$ thick) overlain by six identifiable sub-units rarging in thickness from 4.6 to $37.0 \mathrm{ft}(1.4$ to $11.3 \mathrm{~m})$ (Maldonado and Koether, in preparation). Phenocrysts are generally rare (1\% or less) and small $(<0.3 \mathrm{~mm})$ in the Yucca Mountain Member. Sanidine and plagioclase are the two principal phenocryst phases and are present in approximately equal proportions. Microprobe analyses indicate large feldspar compositional ranges. Anorthoclase, biotite, and hornblende are present in trace amounts. Sphene, zircon, and titanomagnetite are common accessory phases. Lithic fragments of lava(?) make up less than $1 \%$ of the thin sections examined. These lithic fragments are characterized by reddish-brown sanidine phenocrysts. The whole sequence forms a single cooling unit with the central $69 \mathrm{ft}(21 \mathrm{~m})$ being moderately to densely welded, the base and top nonwelded. Three thin sections from the three lowermost subunits were selected for study.

The uppermost sample from a depth of $304 \mathrm{ft}(93 \mathrm{~m})$ is moderately welded and thoroughly devitrified tuff. Flattened shard forms are well preserved, though all glass has crystallized to axiolitic intergrowths of cristobalite and alkali feldspar. Pumice clasts are also flattened and thoroughly devitrified, with elongate-vesicle pumice developing axiolitic textures and 
$6 \mathrm{I}$

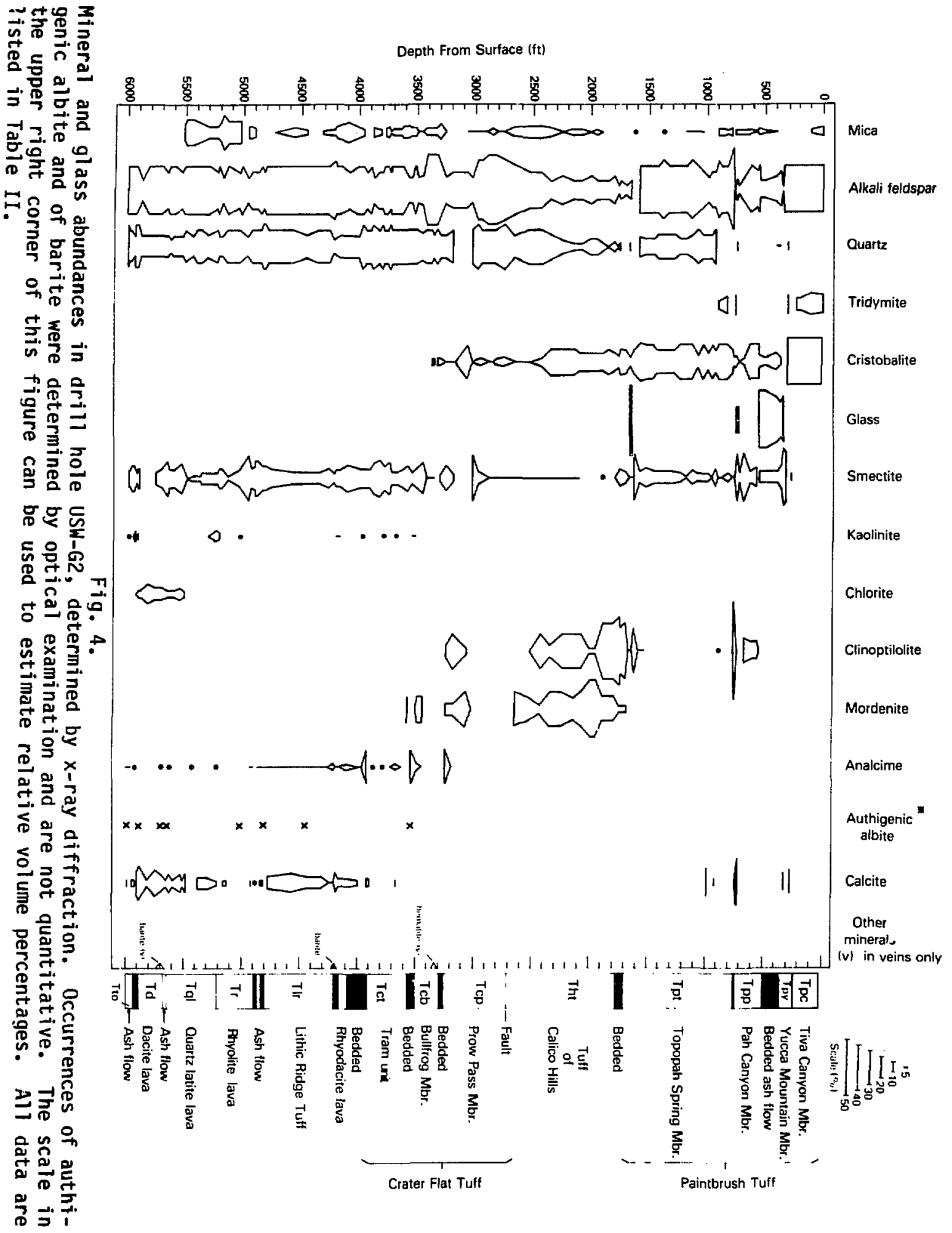


"honeycomb" pumice developing a fine- to coarse-grained granophyric texture. The presence of tridymite in lithophysae, in open pumice, and in groundmass vugs suggests minor vapor-phase crystallization. Low oxidation states of Fe-Ti oxides $\left(C_{1}\right)$ indicate that welding and devitrification have greatly restricted the movement of ground water in this ash flow.

The second sample examined, from a depth of $331 \mathrm{ft}(101 \mathrm{~m})$, is from a slightly to moderately welded devitrified ash flow. The crystallization in this subunit differs significantly from the subunit described above in that a combination of clay and alkali feldspar are the principal secondary minerals. Alkali feldspar occurs as axiolitic crystals in shards and pumice clasts. Clay is an important component of the groundmass and forms feathery axiolitic growths on the outer margins of shards. The Fe-Ti oxide minerals were essentially unoxidized in this sample.

The third sample examined, from the lowermost ash-flow unit at a depth of $338 \mathrm{ft}(103 \mathrm{~m})$, is a nonwelded, vitric ash-flow tuff. Glass shards are randomiy oriented and are up to $1 \mathrm{~mm}$ in maximum dimension. Many delicate shard structures are remarkably well preserved and unbroken vesicles in some shards are partially filled with opal. The groundmass and the outer margins of most glass shards have altered to authigenic clay. However, glass in the central portions of the more massive shards is generally fresh. Glass analyses are summarized in Tabie A-I. The presence of fresh glass and the relatively low oxidation state of the Fe-Ti oxides $\left(C_{2}\right)$ indicates relatively little movement of ground water through this nonwelded unit.

C. "Bedded" Tuff between Yucca Mountain and Pah Canyon Members of the Paintbrush Tuff (341 to $498 \mathrm{ft}, 104.0$ to $151.8 \mathrm{~m})$

An unnamed tuff between the Yucca Mountain and Pah Canyon Members (Fig. 2) consists of thin, reworked tuff overlain by a thick, nonwelded, vitric ash flow (Maldonado and Koether, in preparation). Two samples were examined from the thick ash flow. Phenocrysts make up 5 to $8 \%$ of the ash flow. Sanidine $\left(0 r_{40-50}\right)$ is the most abundant phenocryst phase and occurs as subhedral to euhedral crystals 0.1 to $1.0 \mathrm{~mm}$ long. Hornblende, biotite, and plagioclase are minor but ubiquitous microphenocrysts, with crystal diameters generally <0.3 mm. Sphene, zircon, and titanomagnetite are common accessory minerals. Reddish-brown lithic fragments make up 1 to $\stackrel{n \text { of }}{*}$ of the two samples examined. The predominant type of lithic fragment is of devitrified and vapor-phase 
altered tuff with sanidine phenocrysts. Lithic fragments of rhyolitic lava are less common.

In the thick ash flow, glass shards are smaller $(<0.1 \mathrm{~mm})$ than in the overlying Yucca Mountain Member and fewer well-defined shard structures are preserved. Pumice clasts are major components of both samples examined, making up 50 to $60 \%$ of the rock. The pumice clasts have a complete textural gradation from oper honeycombs to partially open elongate-vesicle pumices and massive vitrophyres. Pumice clasts are supported by a matrix of finely pulverized glass, glass shards, and small pumice fragments. Though most of the glass in this ash flow is unaltered, minor crystallization of clay has occurred around vesicle walls in the pumice clasts. Fe-Ti oxide oxidation states of $C_{2}$ and fresh glass in pumice and shurss indicate minor oxidation and restricted ground-water movement through this unit.

D. Puh Canyon Member of the Paintbrush Tuff (498 to $759 \mathrm{ft}, 151.8$ to $231.5 \mathrm{~m}$ )

The Pah Canyon Member of the Paintbrush Tuff consists of a $28.7 \mathrm{ft}$ $(8.8 \mathrm{~m})$ thick reworked air-fall tuff overlain by five ash-flow subunits ranging in thickness from 12.1 to $101 \mathrm{ft}(3.7$ to $30.8 \mathrm{~m}$ ) (Maldonado and Koether, in preparation). This entire sequence forms a single cooling unit with a moderately welded zone occurring in the 565- to $675-\mathrm{ft}$ (172- to 206-m)-depth interval. Eight thin sections were selected for study and at least one thin section was examined for each major subunit. Phenocrysts make up $1 \%$ of the rock in the lower three subunits and increase to 3 to $6 \%$ in the upper three subunits of the Pah Canyon Member. Sanidine and plagioclase are the principal phenocrysts, occurring in $\sim 60: 40$ proportions. In addition, sanidine mantles many strongly zoned plagioclase phenocrysts. Glomerophyric clots of plagioclase and, to a lesser degree, sanidine are common in most of the thin sections examined. Biotite, augite, and quartz are minor phenocryst phases. Common accessory minerals include sphene, zircon, perrierite, titanomagnetite, ilmenite, and rutile.

Lithic clasts are rare, making up less than $1 \%$ of the rock. The most common fragments are of vapor-phase altered ash-flow tuff with phenocrysts of quartz, plagioclase, sanidine, and biotite. These ash-flow tuffs are sometimes stained by reddish-brown iron oxide, often to the point of being nearly opaque. Clasts of lava are less common. These lava clasts are characterized by phenocrysts of plagioclase and biotite in a feldspar-rich, trachytic groundmass. 
1. Upper and Lower Vitric Zones. Fresh glass is found in the upper 46 ft $(19 \mathrm{~m})$ and the lower $81 \mathrm{ft}(25 \mathrm{~m})$ of the Pah Canyon Member. Alteration of glass to clay is pervasive in the groundmass of the upper vitric zone, but glass shards and pumice clasts are little affected by alteration. Minor clay crystallization has occurred around the margins of glass shards. In the lower vitric zone, glass is fresh in the groundmass as well as in shards and pumice. Significant amounts of calcite occur in open, porous areas of the lowermost vitric ash-flow tuff and in the basal bedded tuff. The calcite was deposited primarily in open vesicles of honeycomb-type pumice and to a lesser extent in elongate-vesicle pumice and in the groundmass. Only minor dissolution of glass has taken place along shard boundaries and pumice walls.

2. Middle Zone of Moderate Welding. Sandwiched between the upper and lower vitric zones and approximately coinciding with the zone of moderate welding is a complex zone of vapor-phase alteration and zeolitization (Figs. 2 and 4). Devitrification has resulted in axiolitic growth of cristobalite and sanidine in some glass shards. Spherulites are common in pumice clasts. Following devitrification, these rocks underwent low-temperature diagenesis, resulting in the replacement of remaining glass by heulandite, clay, and minor opal. Euhedral, blocky crystals of magnesium-rich heulandite project into open vugs left in the groundmass by the dissolution of glass shards and of small pumice fragments. Heulandite also replaces glass within some of the larger pumice clasts. Clay appears to be the dominant groundmass phase, though some heulandite and opal are probably also present. Heulandite analyses and other zeolite analyses for all of USW-G2 are shown in Fig. 5.

Fractures within the moderately welded zone commonly have a thin discontinuous lining of vapor-phase cristobalite and sanidine. Heulandite and opal later partially filled and closed off these fractures. There are no compositional differences between heulandite in the groundmass and in the fractures. The largest of these fractures are perpendicular to the planar foliation imparted by welding and therefore are vertical.

Fe-Ti oxides in the nonweided upper and lower vitric zones are only slightly to moderately oxidized $\left(c_{1}\right.$ to $\left.c_{3}\right)$ even though the rocks are extremely permeable. The presence of large proportions of unaltered glass indicates that these rocks have not been saturated by ground water for any significant period of time and probably resided above the water table since their deposition. Surprisingly, the central, moderately welded zone of the Member 


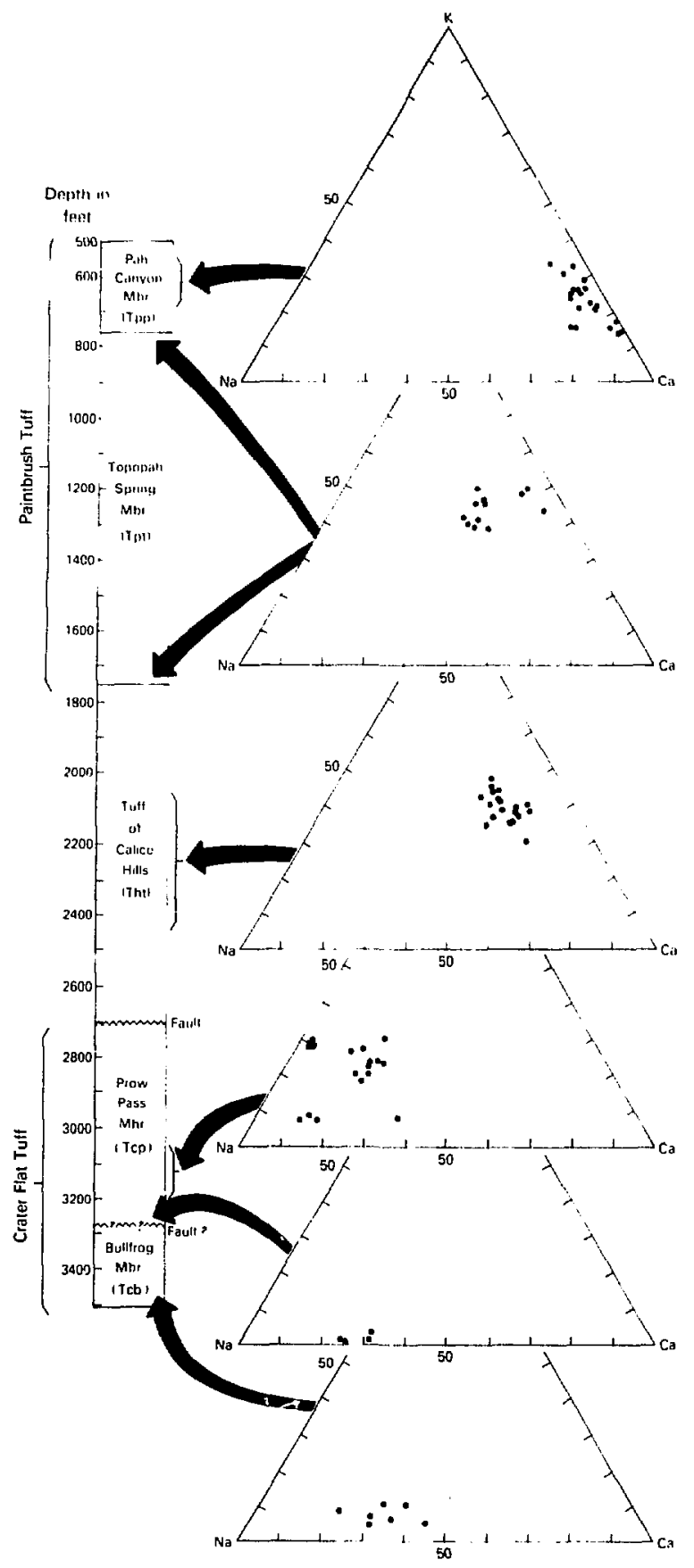

Fig. 5.

Cation compositions on the projection $\mathrm{K}-\mathrm{Na}-\mathrm{Ca}$ for zeolites in drill hole USW-G2.

23 
is characterized by moderately high oxidation states $\left(C_{2}\right.$ to $\left.C_{4}\right)$ in Fe-Ti oxides and the presence of significant amounts of heulandite (up to $30 \%$ ), suggesting partial saturation by ground water. Studies by SEM reveal small amounts of mordenite as well as heulandite (Appendix B, Fig. B-1). Zeolites are unexpected at this stratigraphic interval, especially in a moderately welded, partially crystallized zone sandwiched between two unzeolitized, nonwelded zones. No zeolites have been observed so high above the water table in any of the previous Yucca Mountain drill holes. A perched water table on top of the densely welded Topopah Springs caprock could account for this anomalous occurrence of zeolites. Sealing of porous areas in the lower nonwelded vitric zone by calcite before zeolitization could explain the unexpected lack of zeolites there.

E. Pumiceous Unit Between Pah Canyon and Topopah Spring.

Between the Pah Canyon Member and the Topopah Spring Member is a pumiceous unit. This unit is heavily zeolitized. These zeolites are heulandites (Table A-II and Fig. 5). The lapilli are undeformed, large ( $\leq 5$ $\mathrm{mm}$ ), contain a high amount of void space, and are a light yellow color. The pumices are pseudomorphed by zeolites and by smectite clay. Zeolites fill pumice tubes while the clay lines tube walls. The zeolites occur perpendicular to the fabric of the lapilli. Open voids in pumice are lined by relict opal and chalcedony.

Phenocrysts are a minor proportion $(<2 \%)$ of the lowermost pumiceous unit and are mostly plagioclase. The other phenocrysts are clinopyroxene, unaltered biotite and $\mathrm{Fe}-\mathrm{Ti}$ oxides. The presence of clinopyroxene indicates that this unit may be correlative to the underlying Topopah Spring Member. Lithic fragments include devitrified tuffs, which have partial outer borders of radial chalcedony after opal. Two veins, one open and the other sealed, are present in the sample examined. The sealed vein has minor opal on the outer walls and the remainder is filled by calcite. Calcite rarely fills void space in the pumice.

F. Topopah Spring Member of the Paintbrush Tuff and Underlying Bedded Tuff $(759$ to $1757 \mathrm{ft}, 231.5$ to $535.5 \mathrm{~m})$

The Topopah Spring Member of the Paintbrush Tuff is present in the USW-G2 drill hole from 759 to $1757 \mathrm{ft}(231.5 \mathrm{~m}$ to $535.5 \mathrm{~m})$, with a total thickness of $998 \mathrm{ft}(304.2 \mathrm{~m})$. Twenty-three samples were obtained from this unit, using ash-flow morphology and color as criteria for sample selection. When the 
above criteria were not applicable, sampling intervals of 30 to $50 \mathrm{ft}$ were used. Thin section observations indicate at least five discrete portions of two complex cooling units. The top interval (759-770 ft) ranges from nonwelded at $759 \mathrm{ft}(151.8 \mathrm{~m})$ to vitrophyric at $770 \mathrm{ft}(234.7 \mathrm{~m})$. The vitrophyre ranges from vitric to devitrified over small irregular intervals. The second interval, from 770 to $906 \mathrm{ft}(235$ to $276 \mathrm{~m})$, correlates with the quartz latite caprock of Lipman (1966). This series of rocks is characterized by densely welded, devitrified, vapor-phase altered clinopyroxene-porphyritic tuffs. Third in the series is a thick sequence, from 906 to $1604 \mathrm{ft}$ (235 to $489 \mathrm{~m}$ ), consisting of moderately to densely welded devitrified phenocryst-poor high-silica rhyolite tuff with both vapor-phase and granophyric crystallization. Beneath the thick sequence of devitrified tuffs, 1604 to $1681 \mathrm{ft}$ (489 to $512 \mathrm{~m}$ ), is a series of densely welded to vitrophyric, partly zeolitized tuffs. Included in this fourth group is a lower vitrophyre, $1664 \mathrm{ft}$ (507 m), which is still predominantly glass with minor clinoptilolite filling cracks. The fifth and lowest portion of the Topopah Spring Member, 1681 to $1757 \mathrm{ft}$ $(512$ to $536 \mathrm{~m})$, consists of partly welded to nonwelded zeolitized ash flow. The upper and lower contacts of the Topopah Spring Member are provided by the USGS (Maldonado and Koether, in preparation) and are preliminary.

1. First Interval. The first sample of the Topopah Spring Member described is a densely welded, devitrified to vitrophyric, crystal-rich ash flow. Pumice lapilli in this interval are large $(\leq 7 \mathrm{~mm})$, undeformed, and vitric. Minute rutile needles are disseminated throughout the lapilli and impart a red hue to the clear glass. Perlitic cracks within the pumice are filled with yellow smectite clays. Minor devitrification patches of cristobolite and potassium feldspar are scattered through the pumice. The groundmass of this sample is dark brown due to a high clay content. The matrix is devitrified to spherulites and interlocking sprays of cristobalite and potassium feldspar, comnonly masked by the high clay content of the groundmass.

Shards have two predominant appearances in this sample. The first type is clear and is still glass. The second is tan with intergrown cristobalite and potassium feldspar sheafs oriented parallel to the long dimension of the shards. Other shard replacement textures present in minor amounts are axiolitic and incipient granophyric. All shards are rimed by dark brown clays. 
Phenocrysts are very abundant ( $>20 \%$ by volume) in the upper vitrophyre of the Topopah Spring Member. Both plagioclase and alkali feldspar are common; the plagioclase is typically euhedral. Quartz is strained and often anhedral. Biotite and clinopyroxene are the mafic constituents of this sample, as are unaltered Fe-Ti oxides. Two heavily altered lithic fragments were observed and may be dacitic or trachytic lavas.

2. Second Interval. The second portion of the Topopah Spring Member, 770 to $906 \mathrm{ft},(235$ to $276 \mathrm{~m})$ is the lower devitrified portion of Lipman's (1966) quartz latite caprock. Three samples examined (822, 855, and $898 \mathrm{ft}$ ) are all densely welded, devitrified ash-flow tuffs and are extremely altered by vapor-phase crystalization. This portion may well represent the basal part of the upper cooling unit described in the characterization of the Topopah Spring Member (Carroll et al. 1981).

Pumice lapilli in all three samples are tan to gray in color, flattened, with most original vesicles obscured by devitrification. The outer border regions of all pumices are composed of fine-grained fibrous intergrowths of cristobalite and potassium feldspar that are oriented perpendicular to the outer borders. The inner pumice regions are composed of varying proportions of incomplete spherulites and fine-grained granular aggregates of cristobalite and alkali feldspar. In the pumices of sample 822 the spherulites and granular aggregates are approximately equal in volume. Pumice interiors in sample 855 are mostly granular in texture, and pumice in sample 898 shows abundant mottled spherulites. Overprinted on all pumices are numerous, small $(50 \mu \mathrm{m})$ pockets of tridymite. Clays and oxides are disseminated throughout all pumices and are the final infill products in some tridymite pockets.

Shards and matrix are very similar in the three samples observed. Shards are clear in color and intensely deformed. All are devitrified and range from axiolites to fine-grained granular potassium feldspar and cristobalite that do not cross the shard boundaries. The groundmass is dark brown due to a high clay content. The devitrification products are probably fine-grained cristobalite and potassium feldspar, but most regions are masked by clay. Vapor-phase alteration is common in the matrix as pockets of tridymite.

Lithic fragments are mostly devitrified ash-flow tuffs. Feldspar and quartz phenocrysts are present; biotites are common but are severely oxidized. other mafic phenocrysts are clinopyroxene and heavily oxidized Fe-Ti oxides $\left(C_{6}\right)$ 
Veins and fractures are present with calcite, tridymite, and clay as the filling phases. Veins in sample 822 are partly to wholly filled with tridymite, and the wall rock is altered. At $855 \mathrm{ft}$, one vein is totally sealed by calcite, and the rest are only partly sealed by tridymite and clay. There are three prominent veins in sample 898 , once again with wall rock alteration and only partial fill by tridymite and clay.

3. Third Interval. The third portion of the Topopah Spring Member consists of moderately to densely welded, devitrified ash-flow tuff altered by vapor-phase crystallization. Extending from 906- to 1604-ft (276- to 489-m) depth, this portion contains numerous fractures. Phenocrysts are represented primarily by abundant plagioclase, minor alkali feldspar, and rare quartz. Biotite is observed in all samples but is severely oxidized over the interval 1072 to $1420 \mathrm{ft}(327$ to $433 \mathrm{~m})$. Rare allanite and basaltic oxy-hornblende are also present as mafic phenocrysts. Opaque Fe-Ti oxides are ubiquitous over this portion of the Topopah Spring Member with extreme oxidation exsolution. This oxidation phenomenon in densely welded tuffs is due to interaction with vapor-phase fluids. Lithic fragments in this interval are predominantly of devitrified ash-flow tuff. Heavily altered dacitic fragments are present at 984 and $1032 \mathrm{ft}(300$ and $315 \mathrm{~m})$. The abundance of lithic fragments is relatively high ( 5 to $10 \%$ ) in the lower portion of the densely welded zone from 1420 to $1585 \mathrm{ft}$ (433 to $483 \mathrm{~m}$ ).

Vapor-phase alteration is common in all the moderately to densely welded devitrified tuffs. The alteration is extreme at $921 \mathrm{ft}(281 \mathrm{~m})$, very high over the interval 951 to $1032 \mathrm{ft}$ (200 to $315 \mathrm{~m}$ ), moderate from 1072 to $1133 \mathrm{ft}$ $(327$ to $395 \mathrm{~m}$ ) and high from 1178 to $1536 \mathrm{ft}(359$ to $468 \mathrm{~m})$. The lowest densely welded sample at $1585 \mathrm{ft}(483 \mathrm{~m})$ has sparse vapor-phase alteration in the form of tridymite pockets. The alteration is commonly a light tan color and masks all primary devitrification textures. The alteration is typically a combination of five morphological types consisting of: (1) fine-grained, equant cristobalite and alkali feldspar patches, (2) very large (4 mm), indistinct, mottled lithophysae, (3) pockets of tridymite, which may retrograde to quartz or chalcedony (Appendix Fig. B-2), (4) clear to dirty brown (clay-rich) asymmetric spherulites, and (5) sheaves or sprays of finely intergrown cristobalite and alkali feldspar. These five morphologies represent most of the vapor-phase alteration regions. Lithophysal cavities are common in areas of intense vapor-phase development. These cavities are partially open, and the 
phases growing into the voids are alkali feldspar and tridymite that has retrograded to quartz. All crystals are large $(500 \mu \mathrm{m}$ to $1 \mathrm{~mm})$ and mottled by disseminated clays and oxides. These cavity-lining crystals are separated from the typical vapor-phase regions by a zone of granophyric crystallization with a high abundance of tridymite pockets. Lithophysal cavities are observed in thin section from 1133 to $1536 \mathrm{ft}$ ( 359 to $468 \mathrm{~m}$ ). Tridymite pockets that are common in the devitrified tuffs often have a thin outer border of opal. At depths of 921 and $951 \mathrm{ft}(281$ and $290 \mathrm{~m})$ the tridymite pockets are pristine. Starting at $984 \mathrm{ft}(300 \mathrm{~m})$ the tridymite starts to revert to low-temperature silica phases (chalcedony or quartz). By a depth of $1133 \mathrm{ft}$ $(345 \mathrm{~m}$ ), approximately half of all tridymite pockets have retrograded and those that have remnant tridymite are rimed by thin skins of chalcedony after opal. Approximately $40 \%$ of all pockets to the bottom of the densely welded zone have remnant tridymite.

Pumice pyroclasts in the third interval of the Topopah Spring Member are slightly darker than the shards and range in color from clear to gray to tan to dark red brown (high clay content). Rutile needles are commonly disseminated throughout the pumice lapilli. Original vesicles are commonly masked by devitrification textures. The typical morphology for a devitrified pumice lapilli in this section formed in four stages. First is an outer border region composed of small spherulites, sheaves of cristobalite and/or an axiolitic morphology. In all cases these crystals nucleate at the border and grow toward the center of the clast. Next is a region of interlocking, mottled spherulites 100 to $200 \mu \mathrm{m}$ in diameter, that partially fill the interior of the pumice. Third are vapor-phase crystals of tridymite and alkali feldspar. Finally granophyric crystallization infills the interstitial regions. In extreme cases spherulites completely fill the pumice interiors beyond the border region, or granophyric crystallization totally fills the central portion of the pumice inward from the border region. The pumice texture described is the dominant morphology in most samples. Exceptions occur at (1) 1072-ft (377-m) depth, where an appreciable number of lapilli are devitrified to either lithophysae or to interlocking sheaves of cristobalite and alkali feldspar; (2) 1281- and 1382-ft (390- and 421-m) depth where some pumices are devitrified to the textures described above, and others are devitrified to spherulites only; (3) 1420-ft (433-m) depth where lapilli of the spherulitic zone are replaced by sheaf or spray textures; (4) 1585-ft 
(483-m) depth where all pumices are dominated by large brown mottled spherulites with only interstitial, small-scale granophyric crystallization. Overprinted on all the pumice textures described are an abundance of tridymite pockets produced by vapor-phase alteration. One sample at 921-ft (281-m) depth is so strongly altered by vapor-phase crystallization that no pumices are discernable.

Shard replacement textures in this portion of the Topopah Spring member fall into five major categories: (1) axiolites with or without central granophyric crystallization regions; (2) shards composed of five or six granophyric crystallization grains; (3) shards formed of brown sheaves (composed of cristobalite and alkali feldspar) oriented parallel to the long dimension of the shard, (4) fine-grained, equant aggregates of cristobalite and alkali feldspar, or (5) shards that are crossed by large sprawling brown spherulites that dominate a sample. Type (5) is seen predominantly at 1281 and $1382 \mathrm{ft}$ (390 and $421 \mathrm{~m}$ ), with very minor amounts in the interval 1133 to $1234 \mathrm{ft}$ (345 to $376 \mathrm{~m}$ ). In all the rest of the samples, morphologies (1) and (2) dominate, with granophyric crystallization subequal to axiolitic textures. Sheaf structures (3) are uncommon and are very rare below $1234 \mathrm{ft}(376 \mathrm{~m})$. Type (4) morphology is recognized in minor amounts from 1072 to $1178 \mathrm{ft}$ (327 to $359 \mathrm{~m}$ ) only. In all cases, shards are partly to completely mantled by dark brown clays and disseminated fine-grained oxides. There is also some evidence for authigenic recrystallization of shards (described in Bish et al. 1981) from 1072 to $1331 \mathrm{ft}$ ( 327 to $406 \mathrm{~m})$.

The groundmass of the densely welded third portion of the Topopah Spring Member has high clay content, spherulites, sheaves, and fine- to mediumgrained interlocking and intergrown quartz and alkali feldspar phases. Plumose structures are also present in some samples (e.g., from 921 and 984 $\mathrm{ft}$, or 281 and $300 \mathrm{~m}$ ). In contrast to the above textures, samples from 1281and 1382-ft (390- and 421-m) depth have large, sprawling dirty brown asymmetric spherulites that cross all relict pyroclast boundaries. Overprinted on all samples are the vapor-phase products described above, which preferentially nucleate in the groundmass; the most common of these are pockets of tridymite.

Fractures are common in the densely welded devitrified tuffs and are filled by calcite, zeolites, silica phases, or are still open. The only fracture sealed by calcite occurs at a depth of $984 \mathrm{ft}(300 \mathrm{~m})$. This fracture is a fault, as evidenced by sheared and mylonitized wall rock. The fracture 
seen at $1234 \mathrm{ft}(376 \mathrm{~m})$ is filled by clinoptilolite and then mordenite (Appendix Fig. B-3). Fractures sealed by silica phases occur from a depth of 951 to $1585 \mathrm{ft}$. The fracture in the sample from $951 \mathrm{ft}$ is almost completely filled by tridymite and alkali feldspar. All other fractures sealed by silica phases now contain mosaic quartz with minor alkali feldspar and pockets of remnant tridymite. All fractures sealed in this manner still have 5 to $10 \%$ open void space. Fractures sealed by silica phases may have been partly to totally filled by vapor-phase tridymite and minor alkali feldspar. Subsequently these fractures were recrystallized to mosaic textured quartz with remnant pockets of vapor-phase products left intact. It is likely that these fractures are contraction features formed during initial cooling of the densely welded tuffs, since many were sealed by syngenetic vapor-phase crystallization.

Open fractures are present in $85 \%$ of all samples examined in the densely welded tuffs of the Topopah Spring Member. All fractures at 921-ft depth are open. In the remainder of the samples, 15 to $95 \%$ of all fractures are open. Cross-cutting fracture relations in samples at $1382,1420,1461$, and $1536 \mathrm{ft}$ clearly show that the open fractures are more recent than fractures filled by silica phases. These open fractures are also younger than the minor clay-filled fractures at 1331 and $1461 \mathrm{ft}$. The generation and implication of these open fractures will be discussed later.

4. Fourth Interval. The fourth discrete portion of the Topopah Spring Member, from depths of 1604 to $1669 \mathrm{ft}(489$ to $509 \mathrm{~m})$, consists of densely welded to vitrophyric, zeolitized ash-flow tuff. This interval includes the lower vitrophyre. Phenocrysts in this region are primarily plagioclase. Alkali feldspar and quartz are present in minor amounts, as are unaltered biotite and allanite. Opaque Fe-Ti oxides are moderately to heavily oxidized. Lithic fragments present are devitrified tuffs.

Shards of the densely welded upper sample, 1634-ft (498-m)-depth are dark tan (due to disseminated clays) with clear borders. These shards are completely pseudomorphed by fine-grained clinoptilolite and their central voids are completely filled by larger clinoptilolite crystals. These clinoptilolite crystals are less calcium-rich than those of the overlying Pah Canyon Member (Fig. 5). The matrix is completely recrystallized to clinoptilolite, and all pumice pyroclast are pseudomorphed by clinoptilolite. Perlitic cracks are common in this densely welded sample. Smaller perlitic cracks are filled 
totally by clays; larger cracks are filled by the sequence of opal, clay, clinoptilolite. Fractures are common and connect perlitic cracks and the fill sequence is also opal, clay, and finally clinoptilolite.

Shards and matrix of the lower vitrophyre sample (1664 ft) are tan-towhite unaltered glass. Pumices, which are dark brown, are partially altered to clay and possibly to minor clinoptilolite. There are many small fractures in this sample that are filled by clays and possibly by very fine-grained clinoptilolite.

5. Fifth Interval. The fifth and lowest portion of the Topopah Spring is a nonwelded, zeolitized basal ash-flow tuff, present from 1669 to $1702 \mathrm{ft}$ $(509$ to $519 \mathrm{~m})$. At $1691 \mathrm{ft}(515 \mathrm{~m})$, the phenocrysts and lithic fragments are very similar to the overlying zeolitized densely welded portions of the Topopah Spring Member. Exceptions are the rare occurrence of allanite microphenocrysts and one heavily altered dacitic(?) fragment. Once again, all fractures are sealed by clinoptilolite, mordenite, clays, and opal.

Matrix in the sample from a depth of $1691 \mathrm{ft}(515 \mathrm{~m})$ is tan and consists of a very fine-grained aggregate of clays, mordenite, and clinoptilolite. Shards are clear, totally undeformed, and pseudomorphed by clinoptilolite. There is a thin outer border of yellow clay, then massive crystalline clinoptilolite (10 to $30 \mathrm{\mu m}$ thick) and finally terminated clinoptilolite growing into central voids of the shards. Pumice lapilli are also undeformed and completely pseudomorphed by clinoptilolite and clays. Clays coat all vesicle walls and the zeolite fills the tubes. The pumices are slightly darker tan than the matrix. Most open void space in the pumices is completely filled by clinoptilolite.

6. Bedded Tuff. Unassigned bedded tuff occurs from 1702 to $1757 \mathrm{ft}$ (519 to $535.5 \mathrm{~m}$ ), between the Topopah Spring unit and the Tuff of Calico Hills. This bedded unit is heavily zeolitized, and provides the shallowest occurence of significant mordenite abundances (5-10\%) in drill hole USW-G2. Mordenite abundances increase even more in the underlying Tuff of Calico Hills (Table I). G. Tuff of Calico Hills (1757 to $2704 \mathrm{ft}, 535.5$ to $824.2 \mathrm{~m}$ )

The Tuff of Calico Hills is present in USW-G2 drill core from 1757 to $2704 \mathrm{ft}$ (536 to $824 \mathrm{~m})$, a thickness of $947 \mathrm{ft}(288 \mathrm{~m})$. The base of the unit is faulted against the Prow Pass Member of the Crater Flat Tuff; therefore, $947 \mathrm{ft}$ represents a minimum thickness for this unit. Lithic clasts are common throughout the Calico Hills tuff, making up 1 to $13 \%$ of the thin sections 
examined. The most common type of lithic clast is moderately to densely welded, vapor-phase altered ash-flow tuff. Flattened shard and pumice forms are readily discernable under plane light, even though they are coarsely granophyric and spherulitic. Disseminated iron oxides impart a characteristic brick red color to these lithic clasts in hand specimens. Less common varieties of lithic clasts include zeolitized ash-flow tuff and moderately metamorphosed clasts of quartzite.

The Calico Hills tuffs are made up of 16 nonwelded, zeolitized ash flows ranging in thickness from 4 to $191 \mathrm{ft}(1.2$ to $58 \mathrm{~m})$ (Maldonado and Koether, in preparation). Relatively thin, bedded to massive, reworked and air-fall tuffs 0.2 to $11.7 \mathrm{ft}(0.06$ to $3.6 \mathrm{~m})$ thick separate earh of the ash flows. These intercalated reworked and air-fall tuffs make up only $5 \%$ of the unit volume. Twelve thin sections were selected for study of the nine thickest ash-flow units and of one bedded tuff at a depth of $2001 \mathrm{ft}(610 \mathrm{~m})$.

The Calico Hills tuffs are nonwelded and were once extremely permeable. However, thorough zeolitization has rendered the Calico Hills tuffs relatively impermeable. Fe-Ti oxide oxidation states between $C_{5}$ and $C_{7}$ (Fig. 2), and the presence of abundant zeolites indicate extensive interaction of ground water with these rocks, resulting in the dissolution of glass and in the deposition of low-temperature authigenic minerals. The principal authigenic minerals are clinoptilolite, mordenite, quartz, and K-feldspar. $X$-ray diffraction data show clinoptilolite and mordenite make up 50-80\% of the rock, making the Calico Hills tuff the most thoroughly zeolitized unit in the drill hole. Clinoptilolite (Appendix Fig. B-4) is more abundant than mordenite above a depth of $1952 \mathrm{ft}(595 \mathrm{~m})$; below $1952 \mathrm{ft}$ mordenite abundance is generally equal to or greater than clinoptilolite. Clay is a relatively minor authigenic phase in the Calico Hills tuffs, generally forming $<5 \%$ of the rock.

In most cases shard forms are totally masked by the processes of glass dissolution and zeolite growth. The few discernible shards are crudely pseudomorphed by clinoptilolite. Diagenetic changes in pumices are also extensive and often they too blend imperceptibly into the groundmass, particularly in the lower part of the section. Recognizable pumice textures include two distinct varieties, honeycomb and elongate-vesicle. Fine felty clay often lines vesicle walls in the honeycomb and elongate-vesicle pumices. The glassy framework and the vesicles of these pumice types are totally replaced by a mixture of clinoptilolite and mordenite. 
The groundmass is generally light tan under plane-polarized light and of very low birefringence under cross-polarized light, reflecting the predominance of zeolites. Clay is a relatively minor but ubiquitous component. Small vugs in the groundmass, caused by the dissolution of class and of small pumice clasts, are generally lined and partially filled by euhedral, terminated crystals of clinoptilolite. Mordenite is commonly absent in these vugs except in the lower part of the section. Occasionally opal fills the central portion of vugs lined by clinoptilolite crystals. Usually the original opal has recrystallized into sheaves of acicular quartz crystals. In the bottom half of the Calico Hills section, below a depth of $2300 \mathrm{ft}(701 \mathrm{~m})$, blocky euhedral crystals of authigenic adularia are often intergrown with clinoptilolite in groundmass vugs and in some pumice clasts. These authigenic feldspars yield consistent microprobe analyses of $0 \mathrm{r}_{100^{\circ}}$ The presence of authigenic quartz and adularia in groundmass vugs as well as their abundance in the $x$-ray diffraction data indicate that these minerals are also signficant components of the groundmass, particularly in the lower half of the section. Fractures are small and rare in the groundmass. Most are sealed by zeolites, quartz, and/or clay.

The Calico Hills tuffs can be broken into two major lithologic units based on phenocryst abundance, size, and mineralogy. Phenocrysts in the upper $25 \%$ of the Calico Hills section above a depth of $2011 \mathrm{ft}(613 \mathrm{~m})$ make up only $2 \%$ or less of the rock and are generally of small grain size. Quartz, sanidine, and plagioclase are the principal phenocryst phases and occur in relatively constant proportions of 40:40:20. Biotite is a minor phase and hornblende is a rare trace mineral. Accessory minerals are relatively rare and consist of zircon, magnetite, and allanite(?). Quartz is often resorbed and anhedral, though occasional euhedral crystals are sometimes doubly terminated. Quartz crystals are generally 0.3 to $0.9 \mathrm{~mm}$ long. Most sanidine crystals are subhedral and generally less than $0.7 \mathrm{~mm}$ in diameter, although a few are up $1.5 \mathrm{~mm}$ in diameter. Plagioclase phenocrysts are generally subhedral, slightly zoned, and less than $0.5 \mathrm{~mm}$ long. Biotite laths are euhedral and generally $0.1^{\prime}$ to $0.4 \mathrm{~mm}$ in length. In contrast, phenocrysts below a depth of $2011 \mathrm{ft}(613 \mathrm{~m})$ systematically increase in abundance from 6 to $9 \%$ at the top of the subunit to 15 to $25 \%$ near the base. Quartz, sanidine, and plagioclase are the principal phenocryst phases. Proportions of these major phenocrysts change with increasing depth, with quartz and sanidine the 
dominant phases near the top of the unit and plagioclase and quartz becoming the most abundant phases at depth. Biotite is a minor phase occurring in trace amounts near the top of the subunit, but increases to $1 \%$ of the rock near the base. Accessory minerals, which are relatively rare, consist of zircon, titanomagnetite, and allanite(?). The average size of major and minor phenocryst phases is 2 to 3 times larger in the lower subunit than the upper subunit.

Microprobe analyses record gradual changes in the compositions of biutite and sanidine during emplacement of the Calico Hills tuffs. $\mathrm{Mg} / \mathrm{Mg}+\mathrm{Fe}$ ratios in biotite decrease from 0.44 to 0.47 at the base of the unit to 0.36 to 0.38 near the top. The composition of sanidine changes from $0 r_{71-77}$ at the base of the unit to $0 r_{66-69}$ at the top. The lithologic break at a depth of $2011 \mathrm{ft}$ $(613 \mathrm{~m})$, at which significant changes in phenocryst abundance, size, and mineralogy take place, does not appear to be a compositional hiatus. The chemical changes in biotite and sanidine take place gradually and systematically over the entire unit.

The stratigraphic section of Calico Hills tuff in IISW-G2 (947 ft) is two and a half times thicker than in USW-G1 (376 ft), located $2.6 \mathrm{~km}$ to the south, and two times thicker than in UE25a-1 (472 ft) $4.6 \mathrm{~km}$ to the south-southeast. Although the lower three quarters of Calico Hills tuff in USW-G2 forms a distinct phenocryst-rich subunit, correlative phenocryst-rich tuffs occur only near the base of the USW-G1 section and are apparently absent in UE25a-1. The sections of Calico Hills tuff penetrated by the earlier two drill holes appear to be largely correlative with the upper phenocryst poor subunit in USW-G2. Microprobe compositions of biotite and sanidine in USW-GI (unpublished data courtesy of Richard Warren, Los Alamos National Laboratory) and UE25a-1 (Sykes et al. 1979) are similar to those in the upper Calico Hills section of USW-G2 and support these conclusions. Differences in thickness of the Calico Hills tuff between the three drill holes are probably due to differences in topography at the time of emplacement, though whether or not the topography was erosionally or structurally controlled cannot be determined with the data at hand.

H. Prow Pass Member of the Crater Flat Tuff $(2704$ to $3282 \mathrm{ft}, 824.2$ to $1000.3 \mathrm{~m})$

Preliminary core descriptions (Maldonado and Koether, in preparation) indicate the Prow Pass Member of the Crater Flat Tuff extends from 2704 to 
$3282 \mathrm{ft}(824$ to $1000 \mathrm{~m}$ ) in the USW-G2 core hole. The Prow Pass is bounded on the top by a fault (Fig. 2), which apparently cuts off the top of this unit, and on the bottom by bedded tuffs that extend from 3248- to 3282-ft (990- to $1000-\mathrm{m}$ ) depth and are cut by two additional faults. The Prow Pass in USW-G2 appears to be a single cooling unit that is cut by a mineralized fault at about $3100 \mathrm{ft}(945 \mathrm{~m})$ and by a few minor slickenside and breccia zones. In USW-Gl the complete Prow Pass section is a single cooling unit.

The Prow Pass is characterized by the presence of siltstone and argillite lithic fragments and by pseudomorphs after orthopyroxene. Volcanic lithic fragments also occur in some sections. Phenocrysts form 5 to $20 \%$ of the rock but generally comprise $10 \%$ or less of the total modes. These phenocrysts are severely embayed and resorbed quartz, subhedral alkali feldspar, and altered plagioclase in various stages of replacement. Sparse fresh biotite is present in some sections, but in others it is either absent or has been oxidized and appears opaque.

The oxidation of the upper densely to moderately welded part of the Prow Pass is slightly higher than would be expected. Because four of the six samples studied contain either major fractures or a network of minor fractures, the oxidation could be a result of increased porosity. The two samples most oxidized, at depths of 2950 and $2970 \mathrm{ft}(899$ and $905 \mathrm{~m})$, are the most extensively fractured. The lower, less welded units show the higher oxidation expected, but at $3192 \mathrm{ft}(973 \mathrm{~m})$ a slightiy welded unit overlies a pyrite bearing bedded tuff and may have been reduced. The basal bedded tuff at 3250 $\mathrm{ft}(991 \mathrm{~m})$ is more oxidized than the sample at $3192 \mathrm{ft}(973 \mathrm{~m})$.

The upper part of the Prow Pass (2704 to $2970 \mathrm{ft}, 824$ to $905 \mathrm{~m}$ ) is densely to moderately welded, devitrified, and fractured. The uppermost interval is densely welded; the uppermost, partially welded zone observed in USW-G1 is missing and presumably faulted out. The lower sections are moderately welded, with the exception of a partly welded sample at $2869 \mathrm{ft}$ $(874 \mathrm{~m})$ and a sample at $2950 \mathrm{ft}(999 \mathrm{~m})$ that may be densely weided. All samples are devitrified to silica and feldspar, as fine-grained equigranular groundmass or as spherulitic areas between pumice pyroclasts.

Sections between 2744 and $2970 \mathrm{ft}(836$ and $905 \mathrm{~m})$ contain major fractures. Sections between 2950 and $2970 \mathrm{ft}(899$ and $905 \mathrm{~m})$ contain minor fractures throughout. One fracture at $2744 \mathrm{ft}(836 \mathrm{~m})$ is 0.3 to $0.55 \mathrm{~mm}$ wide and is filled with fine-grained $(\leq 0.05 \mathrm{~mm})$ silica and varying amounts of 
opaque oxides, including amorphous MnO. This fracture contains rare phenocryst fragments from the host tuff. A bleached zone extends approximately $1 \mathrm{~mm}$ on each side of the vein. Another fracture at $2869 \mathrm{ft}(874 \mathrm{~m})$ depth is 0.1 to $0.3 \mathrm{~mm}$ wide and is filled with microcrystalline $(\leq 0.01 \mathrm{~mm})$ silica and contains fragments of phenocrysts up to $0.1 \mathrm{~mm}$ across and groundmass from the surrounding rock. The microfractures at $2950 \mathrm{ft}(899 \mathrm{~m})$ depth are filled with silica and minor clay. At $2970 \mathrm{ft}(905 \mathrm{~m})$ all the fractures are filled with hematite-stained silica. A major fracture at this depth varies in width from 0.7 to $1.4 \mathrm{~mm}$ and contains abundant rock and phenocryst fragments in a redstained microcrystalline $(\leq 0.005 \mathrm{~mm})$ silica matrix. This sample is just above the brecciated probable fault zone from 2971 to $2994 \mathrm{ft}(905.5$ to $912.6 \mathrm{~m})$ depth (Maldonado and Koether, in preparation).

Samples from the lower part of the Prow Pass are slightly welded to nonwelded tuffs in which pyroclasts are largely replaced by secondary minerals. At a depth of $3037 \mathrm{ft}(926 \mathrm{~m})$ there are abundant clays, and abundant zeolites occur between 3067- to 3192-ft (935- to 973-m) depth. A sample at 3037-ft (926-m) depth is the most lithic rich $(7-10 \%)$ of any examined. It is also altered almost completely to clays that obscure the original texture. The groundmass and shards of samples between 3067 and $3192 \mathrm{ft}$ (935 and $973 \mathrm{~m}$ ) are replaced by the zeolites clinoptilolite and mordenite (Fig. 6). Pumice pyroclasts at $3067 \mathrm{ft}(935 \mathrm{~m})$ are devitrified to silica and feldspar, and the pumices at $3192 \mathrm{ft}(973 \mathrm{~m})$ has altered mostly to clays. Zeolites first appear in the x-ray diffraction patterns at 3037-ft (926-m) depth (mordenite) and become more abundant through $3192 \mathrm{ft}$ (mordenite and clinoptilolite). Clinoptilolite occurs predominantly in shards, whereas mordenite occurs more commonly in the groundmass or as void fillings. A trace of analcime was also seen in the $x$-ray diffraction pattern of a sample at 3192-ft (973-m) depth.

The bedded tuff at the base of the Prow Pass $(3250 \mathrm{ft}, 991 \mathrm{~m})$ shows cross bedding but does not appear to be extensively reworked because of the preservation of delicate shard morphology. This interval may be a surge deposit. The shards and groundmass have been replaced by analcime, clinoptilolite, and mordenite. Only clinoptilolite and mordenite show up in the electron microprobe analyses, as only the crystals in shards and pumice are large enough to analyze. 


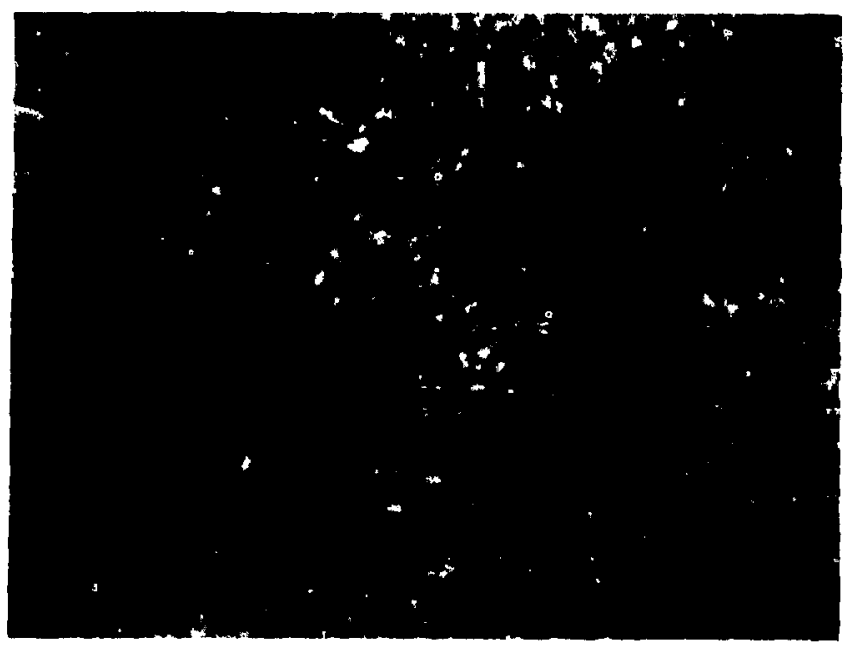

Fig. 6 .

Position of a shard pseudomorphed by clinoptilolite and mordenite. Clinoptilolite viewed as massive border region and long acicular crystals. Mordenite is the aggregate of radial growths. Clays infill central portion of shard. Sample USW-G2 3192, plane light, field of view is $0.27 \mathrm{~mm}$.

I. Bullfrog Member of the Crater Flat Tuff $(3282$ to $3574 \mathrm{ft}, 1000.3$ to $1089.4 \mathrm{~m}$ )

The Bullfrog Member of the Crater Flat tuff extends from 3282 to $3574 \mathrm{ft}$ (1000.3 to $1089.4 \mathrm{~m}$ ) in drill hole USW-G2. The Bullfrog Member is overlain by $2.4 \mathrm{ft}(0.7 \mathrm{~m})$ of ash fall lapilli-lithic tuff below the nearest fault. Another fault at $3339 \mathrm{ft}(1017.7 \mathrm{~m}), 57 \mathrm{ft}(17.4 \mathrm{~m})$ below the top of the Bullfrog (Fig. 2), may cut out as much at $150 \mathrm{ft}(50 \mathrm{~m}$ ) of the upper part of the Bullfrog (Maldonado, in preparation).

Two units of the Bullfrog Member are separated by a reworked, bedded tuff, which is described from drill hole USW-G1 (Bish et al. 1981). This separation does not occur in the USW-G2 drill core and the entire interval appears to be one cooling unit. The uppermost sample $[3308 \mathrm{ft}(1008 \mathrm{~m})]$ is moderately welded, and the degree of welding decreases with depth to a nonwelded flow at the base of the Bullfrog Member, overlying bedded tuffs. The upper part of the Bullfrog Member has vapor-phase crystallization that is most extensive at $3308-\mathrm{ft}(1008-\mathrm{m})$ depth. A sample from $3416 \mathrm{ft}(1041 \mathrm{~m})$ is coarsely devitrified and partially welded. Another sample from $3492 \mathrm{ft}$ (1064 $m$ ) represents the nonwelded base of the unit and is extensively zeolitized 
(mordenite and analcime). The analcime is apparently in the groundmass, as it was not visible. The pumices have been altered and replaced by clay (Appendix Fig. B-5).

The Bullfrog Member contains about $15 \%$ quartz phenocrysts, and plagioclase is more abundant than alkali feldspar. The uppermost sample contains pseudomorphs after pyroxene as well as hornblende. Fresh biotite occurs in all samples. Pumices form 10 to $25 \%$ of the Bullfrog samples. Zircon occurs as an accessory phase.

The oxidation states of the Fe-Ti oxides in the Bullfrog seem to result from a combination of factors. The expected pattern of lower oxidation in the upper moderately welded tuff and higher oxidation in the nonwelded basal unit is not seen. The two lower samples both contain pyrite, indicating lower oxidation in nonwelded samples than in partially welded samples. Samples just above the pyrite zone have a low oxidation state that may result from reduction peripheral to the pyrite zone and from welding effects. The bedded tuff below the Bullfrog ( $3541 \mathrm{ft}$ ) contains sulfides of a lower oxidation state than otherwise expected for a nonwelded unit.

Like the Prow Pass, the Bullfrog consists of nonwelded and slightly welded ash-flow tuff at the base, and both members terminate abruptly upward within the moderately to densely welded part of the cooling unit. Unlike the Prow Pass, the Bullfrog is not cut off by a fault, rather it is overlain by a bedded tuff. This suggests a possible erosional surface between the moderately welded Bullfrog and the air-fall above it.

Samples from the bedded tuff directly below the Bullfrog Member contains more alkali feldspar than plagioclase and are lithic rich (approximately 10\%). $X$-ray diffraction studies suggest abundant analcime, but optical petrography and microprobe analyses of shards reveal only authigenic albite. Analcime may be abundant within the very fine-grained groundmass.

J. Tram Member of the Crater Flat Tuff and Underlying Bedded Tuff (3574 to $4079 \mathrm{ft}, 1089$ to $1243 \mathrm{~m}$ )

The Tram Member of the Crater Flat Tuff consists of a sequence of partially welded lithic-rich ash-flow tuffs and underlying, unassigned bedded tuffs [totalling $165 \mathrm{ft}(50.3 \mathrm{~m})$ in thickness] that may be air-fall deposits. Within USW-G2, the Tram occurs between depths of $3574 \mathrm{ft}$ to $3914 \mathrm{ft}$ (1089 m to $1193 \mathrm{~m}$ ), with a combined thickness of $340 \mathrm{ft}(103.6 \mathrm{~m}$ ) (Maldonado and Koether, in preparation). The entire section is cut by faults (or shears tentatively 
identified as faults) at depths of $3894.8 \mathrm{ft}(1187.1 \mathrm{~m}), 4070 \mathrm{ft}(1240.5 \mathrm{~m})$, $4074.8 \mathrm{ft}(1242 \mathrm{~m})$, and $4077.4 \mathrm{ft}(1242.8 \mathrm{~m})$ (Maldonado, in preparation). Petrographic descriptions allow the Tram Member at this borehole to be broken into three subunits.

1. Tram Member at Depths of 3574 to $3914 \mathrm{ft}(1089.3$ to $1193 \mathrm{~m})$. This section was logged as a pair of lithic-rich ash flow tuffs (Maldonado and Koether, in preparation). The upper is more lithic-rich than the lower; both are nonwelded to moderately welded tuffs. Phenocrysts make up 15 to $20 \%$ of both units and include: (a) Anhedral to subhedral, 450- $\mu \mathrm{m}-$ to $2-\mathrm{mm}-1$ ong plagioclase, most of which have been broken; the angular 300- to 400-um-long chips are scattered throughout the matrix. Most of the plagioclase grains exhibit oscillatory zoning and have a range of compositions from $\mathrm{An}_{1} \mathrm{Ab}_{75} \mathrm{Or}_{6}$ to $\mathrm{An}_{40} \mathrm{Ab}_{55} \mathrm{Or}_{5}$. (b) Oxidized Fe-Ti oxides (averages of $\mathrm{C}_{5}$ to $\mathrm{C}_{7}$ ). (c) Sanidine occurs as equant, subhedral grains 1 to $1.5 \mathrm{~mm}$ in diameter $\left(A_{3} b_{33}{ } r_{67}\right)$. (d) Quartz is present as equant, subhedral phases 0.2 to $2 \mathrm{~mm}$ long; there are also numerous elongate fragments. (e) Biotites are present as subhedral, ragged, $0.3-$ to $0.73-\mathrm{mm}-1$ ong crystals.

Lithic fragments within the Tram Member make up as much as $90 \%$ of the rock in the upper unit. Most of these fragments consist of subrounded to subangular volcanic rocks. None are fresh and all have been altered to some extent, with groundmass and matrix minerals replaced by smectites, hematite, and authigenic $K$-feldspar, and some plagioclase phenocrysts partly replaced by calcite. The most common volcanic lithic fragments are andesitic lavas and older ash-flow tuffs with faint relict vitroclastic textures. In lesser amounts are older pumice pyroclasts, one metasediment fragment and a broken spherulite.

Within the Tram, relict shards are well preserved. Forty to fifty percent of the matrix consists of 2- to 4-mm-long, slightly elongate pumice pyroclasts and delicate shards with thin vesicle walls. Relict shards and pumice pyroclasts are outlined by chains of $0.5-\mu \mathrm{m}-$ to $2-\mu \mathrm{m}-1$ long, equant, anhedral hematite grains. Delicate vesicle walls projecting from pumices have not broken off and exhibit no rounding. Most of the shards have been derived from a vesiculated melt with ovoid vesicles; only the more elongate pumice pyroclasts are characterized by closely spaced, highly elongate vesicles.

Relict shards and pumice pyroclasts have been replaced by colorless to pale brown anhedral, equant, phases $3 \mu \mathrm{m}$ to $20 \mu \mathrm{m}$ in diameter with very low 
birefringence. Most of the well-defined relict pyroclasts have been replaced by analcime, except near the base of this sequence, where they have been replaced by pale brown smectites.

Space between relict pyroclasts, phenocrysts, and lithic fragments has been filled with finely crystalline ( $<2 \mu \mathrm{m})$ equant, colorless to pale brown phases, and subhedral hematite grains. The matrix consists of a mixture of cristobalite, analcime, smectites, and lesser amounts of authigenic alkalifeldspar. Vesicles in some of the larger pumice pyroclasts contain mediumbrown smectites and calcite. A simiiar mix, with clusters of the phases listed above, has replaced matrix and groundmass in many of the lithic fragments.

Within the upper part of this unit, cracks of $<10-\mu \mathrm{m}$ to $150-\mu \mathrm{m}$ width are filled with calcite. Lower in this sequence, there are no visible cracks.

2. Bedded Tuff at Depths of 3914 to $3982 \mathrm{ft}(1193$ to $1213.7 \mathrm{~m})$. This 68-ft- (20.7-m)-thick tuff unit has been described by Maldonado and Koether (in preparation) as a bedded tuff with finely laminated 5-cm- to 3-m-thick beds. The sample collected from this unit is a moderately welded tuff.

The variety of phenocrysts is the same as described for the top subunit. Most phenocrysts are shattered and some exhibit undulose extinction (as if they had been strained during the eruption). Relict textures are very difficult to identify; faint patterns indicating slightly compacted, welded pumice pyroclasts make up over $50 \%$ of this sample. These 1 - to $4-\mathrm{mm}-1$ ong, wispy, doubly terminated pyroclasts have been replaced by equant, 8- to 24- $\mu \mathrm{m}$, colorless, and brown phases. In reflected light, the brown phases with low relief are smectites and high-relief, colorless phases are mixtures of cristobalite, authigenic K-feldspar and zeolites. The same phases make up the finely crystalline fill between pyroclasts, along with about $5 \%$ calcite. There are traces of a very finely crystalline green phase that may be chlorite. Pyrite is also seen disseminated throughout the tuff.

3. Air-fall Tuff Located at a Depth of 3982 to $4079 \mathrm{ft}(1213.7$ to $1243 \mathrm{~m})$. This is a nonwelded, crystal-rich tuff. Nearly all phenocrysts in this crystal-rich (40\%) tuff are subhedral or anhedral fragments, having been comminuted during the eruption. All phenocrysts range in size from $10 \mu \mathrm{m}$ to 3 $\mathrm{mm}$ long. These consist of plagioclase $\left(\mathrm{An}_{22} \mathrm{Ab}_{73} O \mathrm{r}_{5}\right.$ to $\left.\mathrm{An}_{43}{ }^{A b_{54}} \mathrm{Or}_{3}\right)$, quartz, highly altered amphibole and biotite, and $\mathrm{Fe}-\mathrm{Ti}$ oxides (average $\mathrm{C}_{7}$ to $\mathrm{C}_{2}$; the latter sample is associated with a nonwelded tuff near the base of the 
section). Many of the plagioclase phenocrysts have been replaced, in part, by calcite.

Lithic fragments, which make up 7 to $10 \%$ of the rock, consist mostly of older tuffs (hematite-stained, spherulitic varieties) and pale brown lava (with faint flow-banding in what appears to have been an originally glassy groundmass).

The matrix consists of about $50 \%$ relict shards and pumice pyroclasts surrounded by very finely crystalline, light-brown to orange-brown phases. Relict shards have been replaced by $1-$ to $3-\mu \mathrm{m}$ fibrous phases (smectite) along

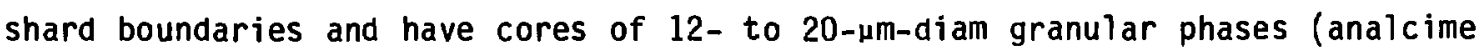
and smectite). All relict pyroclasts are outlined by finely crystalline hematite grains. Pumice pyroclasts are thin, ragged elongate relicts replaced by pale-brown smectites. Some pumices are aphyric but others contain glomeroporphyritic clots of plagioclase, biotite, and Fe-Ti oxides.

Spaces between pyroclasts are filled with finely crystalline red-brown smectites and colorless or light-brown cristobolite. Some of the void space in the matrix has been filled with calcite and analcime.

K. Hornblende-biotite Rhyodacite Lava (4079 to $4150 \mathrm{ft}, 1243$ to $1264.9 \mathrm{~m}$ )

The rhyodacite lava includes an upper zone of plagioclase-biotitehornblende porphyritic flow breccia and a lower plagioclase-hornblende-biotite porphyritic lava flow. The petrographic descriptions listed here are taken from the upper flow breccia at 4090-ft $(1247-\mathrm{m})$ depth, and from the slightly brecciated flow interior at $4124-\mathrm{ft}(1258-\mathrm{m})$ depth. In the upper flow breccia, plagioclase is by far the commonest phenocryst ( $20 \%$ of the sample), with a compositional range from labradorite $\left(A n_{57}\right)$ to andesine $\left(A n_{41}\right)$. Biotite is well preserved, although relict amphiboles are completely replaced by calcite and opaque minerals. This dense lava has Fe-Ti oxide minerals with only slight oxidation-exsolution. Zircon is a rare accessory mineral. A few vesicular lava fragments have been incorporated into the flow breccia; these fragments are collapsed and have a complex range of recrystallization features. Within the scale of a single thin section, these vesicular fragments may be replaced either by a granular intergrowth of quartz and feldspar, or by massive blue clay. X-ray diffraction studies of these blue clays suggest that they are composed of about $20 \%$ illite and $80 \%$ expandable smectite. Clay analyses are listed in Table A-IV. 
The hornblende-biotite rhyodacite lava at $4124 \mathrm{ft}(1258 \mathrm{~m})$ is more representative of this lava unit. The lava contains about 20\% labradoriteandesite, $10 \%$ hornblende, and $5 \%$ biotite phenocrysts. Much of the sample matrix at $4124-\mathrm{ft}$ depth is replaced by analcime, but clays outline relict perlitic cracks; apparently this flow was originally vitrophyric. Accessory phases include apatite and zircon. There are rare pseudomorphs after clinopyroxene(?). Oxidation-exsolution of the Fe-Ti oxides is the same in the center of the flow $\left(C_{2}\right)$ as in the brecciated flow top.

$\mathrm{Clays}$ occur throughout the groundmass of this rhyodacite unit. Carbonate growths may cut across the earlier replacement textures in the groundmass. Small fractures are common but are completely sealed by quartz and clay. Quartz pseudomorphs after botryoidal opal(?) occur in the brecciated flow top near the vein walls, and the vein centers are filled with coarse granular quartz. Where clay is associated with vein fillings, it occurs as an early-formed phase near the vein walls.

L. Bedded Tuff above the Lithic Ridge Tuff $(4150$ to $4195 \mathrm{ft}, 1264.9$ to $1278.6 \mathrm{~m}$ )

A thin bedded interval separates the rhyodacite lava from the Lithic Ridge Tuff. This bedded interval is a rhyodacitic crystal-lithic tuff and is included stratigraphically with the rhyodacite lava and flow breccia in Fig. 1. The most abundant phenocryst phase (25\% of the sample) is oscillatory zoned plagioclase. Biotite phenocrysts and relict amphibole phenocrysts replaced by calcite are minor constituents of the bedded tuff. Small quartz phenocrysts are very rare. Both apatite and zircon are present as accessory phases. The Fe-Ti oxide minerals are more oxidized in this bedded tuff than in the dense lava above or in the dense Lithic Ridge caprock below (Fig. 2). Lithic fragments are plagioclase-biotite rhyodacites, perhaps related to the dominant parent lithology for this reworked interval. The pumice fragments are recrystallized to granular quartz-feldspar intergrowths with no remnant void space, although apple-green spheroids of intergrown quartz, feldspar, and clay may represent relict vesicles in pumice (Appendix Fig. B-6).

The groundmass of this bedded tuff is heavily recrystallized to granular quartz plus feldspar intergrowths. Clays are abundant in the groundmass, following a grid pattern that may be continuous in three dimensions. Calcite is al so abundant in the groundmass, although calcite grains are larger than the 
clays and less evenly distributed. Calcite crystals may be up to $1 \mathrm{~mm}$ in diameter.

M. Lithic Ridge Tuff (4195 to $4803 \mathrm{ft}, 1278.6$ to $1464.0 \mathrm{~m}$ )

The Lithic Ridge Tuff occurs at a depth of 3946 to $4940 \mathrm{ft}$ (1203 to 1506 $m$ ) in arill hole USW-GI; previous reports on USW-GI refer to this unit as the "Lithic-rich Tuff" (Bish et al. 1981). Although the Lithic Ridge Tuff in USW-G1 is thicker than in USW-G2, the section in USW-G2 includes a densely welded caprock whereas the USW-GI section is nonwelded to partly welded throughout. The densely welded caprock of the Lithic Ridge Tuff is crystalrich, unlike the underlying crystal-lithic to lithic-crystal tuffs that form the bulk of the Lithic Ridge Tuff. The caprock also lacks potassium feldspar phenocrysts, unlike the underlying part of this unit. The thin caprock ( 88 $\mathrm{ft}, 2.5 \mathrm{~m}$ ) is distinct from all other samples of the Lithic Ridge Tuff, but the lack of any notable break between it and the underlying Lithic Ridge Tuff suggests that it is the final mafic phase of the Lithic Ridge ash flow eruptive cycle, and not a separate unit.

The caprock of the Lithic Ridge Tuff in USW-G2 is a densely welded crystal-rich (andesine) tuff. Andesine phenocrysts range in composition from $\mathrm{An}_{51}$ to $\mathrm{An}_{33}$, with oscillatory zoning. Partial to complete replacement by calcite is common among the andesine phenocrysts. The plagioclase phenocrysts represent about $20 \%$ of the sample from $4199-\mathrm{ft}$ depth; phenocrysts of biotite, with apatite inclusions, and of quartz are much more rare ( $<1 \%$ of each). The oxidation-exsolution of $\mathrm{Fe}-\mathrm{Ti}$ oxides is greatly restricted in the caprock (CI) but increases markedly $\left(C_{2}\right.$ to $\left.C_{6}\right)$ with depth in the underlying poorly welded portions of the Lithic Ridge Tuff. The occurrence of sulfide minerals is also restricted to the caprock. Apatite is a common accessory phase. The rare lithic fragments include recrystallized ash-flow tuff and a quartzfeldspar-biotite volcanic breccia. Pumices are abundant ( $15 \%$ of the sample) and intensely flattened; many contain calcite pseudomorphs after plagioclase and abundant opaque clay. The groundmass includes granular quartz-feldspar intergrowths replacing glass shards. Clays are concentrated in the relict pumices, and the surrounding groundmass is composed primarily of quartz and feldspar with a later generation of patchy microcrystalline calcite.

The lower $600 \mathrm{ft}(183 \mathrm{~m})$ of the Lithic Ridge Tuff below the caprock is nonwelded to slightly welded, with locally abundant inclusions of accidental lithic fragments. Among the most lithic-rich samples is one at $4209 \mathrm{ft}$ 
(1283 $\mathrm{m})$, just under the caprock, where volcanic fragments form more than $50 \%$ of the tuff. Lower in the unit, lithic fragments account for as little as 3 to $5 \%$ of the tuff. Phenocryst assemblages vary from plagioclase predominant (7\%) high in the unit to potassium-feldspar predominant (6\%) toward the base of the unit. The inverse zonation from andesine-porphyritic caprock down through oligoclase-porphyritic to sanidine-porphyritic tuffs suggests the top-to-bottom disgorgement of a compositionally zoned magma chamber. The total feldspar content at all depths averages about $10 \%$ with minor variations. This two-feldspar assemblage is formed of unzoned to poorly normal or oscillatory zoned oligoclase $\left(\mathrm{An}_{37}\right.$ to $\left.A n_{15}\right)$ and sanidine $\left(0 \mathrm{r}_{65}\right)$. Replacement of plagioclase by clay is common at the top of the Lithic Ridge Tuff; towards the bottom of this unit the replacement of plagioclase by calcite becomes more common. Sanidine phenocrysts are less affected by alteration. Quartz phenocrysts form 2 to $5 \%$ of these samples; biotite phenocrysts are ubiquitous but less abundant. Both zircon and apatite occur as accessory minerals.

Pumices are only slightly flattened, although the relict vesicles are filled in by calcite or clay. Replacement of pumices by calcite is common at the top of the nonwelded Lithic Ridge Tuff, whereas replacement by clay becomes more common toward the bottom. This transition from calcite to clay replacement with depth is the inverse of the replacement phenomena in the feldspar phenocrysts. In part, this may be because the primary plagioclase grains tend to react with the matrix and with pore fluids to form the authigenic assemblage calcite + albite at depth.

The population of lithic fragments is diverse. Mixed fragments of biotite-hornblende rhyodacitic rocks and felsic silicic volcanic rocks and spherulites are abundant throughout the nonwelded Lithic Ridge Tuff. Most of these fragments have been intensely altered, in a manner comparable to the alteration of the host groundmass.

Groundmass alteration is intense throughout the Lithic Ridge Tuff. Relict shards are commonly replaced both by calcite and by granular quartz-feldspar intergrowths. In rare instances authigenic albite has grown along the walls of shards, and the central portions of the shards are replaced by calcite. Clays occur scattered throughout the groundmass or concentrated 
in relict pumices toward the base of the unit. Blue clay is concentrated in relict pumice at $4467-\mathrm{ft}$ depth; this blue clay has the composition

$$
\mathrm{K}_{1.4}\left(\mathrm{M}^{2+}{ }_{1}^{\mathrm{Al}} \mathrm{I}_{3}\right)\left(\mathrm{Si}_{7} \mathrm{Al}_{1}\right) \mathrm{O}_{20} \mathrm{OH}_{4} \text {, }
$$

where $\mathrm{M}^{2+}=\mathrm{Fe}$ or $\mathrm{Mg}$ (Table A-IV). Within narrow limits, this composition is typical of the interstratified smectite-illite clays that occur from this depth to the bottom of the arill core. X-ray diffraction studies indicate that analcime may occur in trace amounts throughout the Lithic Ridge Tuff. Crystals of analcime are not coarse enough to be seen in thin section. N. Bedded Tuff and Ash Flow at the Base of the Lithic Ridge Tuff (4803 to $4874 \mathrm{ft}, 1464.0$ to $1485.6 \mathrm{~m})$

The bedded tuff at the base of the Lithic Ridge Tuff is pumice-rich, with about $10 \%$ altered feldspar phenocrysts. Alteration of plagioclase to calcite is severe, and the remaining plagioclase is typically pure albite with only regions of moderate anorthite content. Sanidine crystals are the smaller and less abundant of the feldspar phenocrysts but tend to be better preserved with $0 r_{65}$ compositions. Authigenic potassium feldspar is common, however, with $0 r_{97}$ to $0 r_{99}$ compositions. Quartz and relic biotite are less abundant as phenocrysts. Accessory minerals include zircon and apatite.

The rare lithic fragments are spherulites. Most of the bedded tuff sample at $4805-\mathrm{ft}$ depth consists of pumice fragments that are replaced by granular intergrowths of quartz and feldspar. Some pumice fragments contain voids lined by euhedral authigenic albite. Birefringent clays are concentrated in the seams between pumice fragments.

A thin, slightly welded ash flow occurs in the depth interval $4827 \mathrm{ft}$ to $4856 \mathrm{ft}$ (1471 to $1480 \mathrm{~m}$ ) within the bedded tuff. This ash flow is a crystal-rich tuff with about $10 \%$ plagioclase phenocrysts and far fewer phenocrysts of quartz, biotite, and potassium feldspar. The Fe-Ti oxide minerals in both the ash flow and the surrounding bedded tuff have undergone comparable oxidation-exsolution $\left(\mathrm{C}_{5}\right)$. Zircon and apatite occur as accessory phases, and the rare lithic fragments are spherulitic. This 29-ft (8.8-m)-thick ash flow may correlate with the $15-\mathrm{ft}(4.6-\mathrm{m})$-thick ash flow that occurs between the depths of 5434 and $5449 \mathrm{ft}$ (1656 and $1661 \mathrm{~m}$ ) in drill hole USW-Gl. The thin correlative ash flow in USW-G1, however, occurs within Unit B of the older 
tuffs, $513 \mathrm{ft}(156.3 \mathrm{~m})$ below the base of the Lithic Ridge Tuff, in contrast to only $24 \mathrm{ft}(7.3 \mathrm{~m})$ below it in USW-G2.

The pumices and the matrix of this ash flow in USW-G2 are replaced by quartz-feldspar intergrowths, with some calcite. Clays are concentrated around pumice remnants. Voids lined by authigenic albite are not as common as in the surrounding bedded turf.

0. Rhyolite Lava (4874 to $5200 \mathrm{ft}, 1485.6$ to $1585.0 \mathrm{~m}$ )

A plagioclase-biotite porphyritic rhyolite lava (or lava series) forms the upper part of a $725 \mathrm{-ft}-(221-\mathrm{m})$-thick lava sequence below the Lithic Ridge Tuff. A sample of the rhyolite lava at $5017-\mathrm{ft}$ (1529-m) depth contains 5\% very slightly zoned andesine phenocrysts $\left(A n_{38}-A n_{29}\right)$ with thin sanidine rims. Biotite phenocrysts are rare; minor alteration of biotite to a pale-green mica with low birefringence suggests incipient alteration to chlorite. Most of the middle part of this flow is particularly dense and free from brecciation; as a result, the Fe-Ti oxide minerals are less oxidized $\left(C_{1}\right)$ than the oxide minerals $\left(C_{5}\right)$ in upper and lower brecciated portions of the rhyolite lava (Fig. 2). The groundmass is replaced by an intergrowth of quartz and potassium feldspar (Appendix Fig. B-7). Spherulitic growths of quartz + albite + potassium feldspar are abundant, crosscutting the relict flow banding within the groundmass. The abundance of quartz and alkali feldspar within the groundmass permits this unit to be called a rhyolite.

The lava sample at $5017-\mathrm{ft}(1529-\mathrm{m})$ depth contains few fractures, no voids, and almost no authigenic minerals with the exception of some illite/smectite and some striking plumose growths of bladed albite. The plumose albite growths crosscut spherulites but parallel the flow banding. These striking albite growths are probably a very early stage of authigenic crystal growth.

Elsewhere within the rhyolite lava there are severely brecciated zones, especially in the lower part. Portions of the lava in these zones may contain far fewer plagioclase phenocrysts, and more biotite phenocrysts plus rare relict amphibole phenocrysts. Zircon and apatite are common accessory minerals throughout.

Fractures within the brecciated lava series are filled by granular quartz, or the fracture walls may be lined by authigenic albite and only the fracture centers are filled by granular quartz. Calcite occurs within the groundmass of the brecciated lavas but not within the later-formed fractures. 
P. Quartz Latite Lava (5200 to $5637 \mathrm{ft}, 1585.0$ to $1718.2 \mathrm{~m}$ )

A plagioclase-amphibole-biotite-pyroxene porphyritic lava or lava series forms the lower 437-ft (133-m) of the 725-ft-(221-m)-thick lava sequence below the Lithic Ridge Tuff (Fig. 2). Plagioclase phenocrysts form about $10 \%$ of these samples, with lesser subequal amounts of biotite and relict amphibole (about $4 \%$ total) and with rare but characteristic granular quartz pseudomorphs after pyroxene. The pseudomorphs of pyroxene are a significant difference between this unit and the overlying rhyolite lava. Apatite and zircon are common accessory minerals; sphene is rare. Oxidation-exsolution within Fe-Ti oxide minerals is somewhat greater at the top of the quartz latite lava $\left(C_{6}\right)$ than at the bottom $\left(C_{4}\right)$. Pyrite occurs at $5305 \mathrm{ft}$; this is the deepest occurrence of pyrite within USW-G2. The plagioclase phenocrysts may form glomeroporphyritic clots and have slight normal zoning $\left(A n_{43}\right.$ to $\left.A_{29}\right)$. These flows are called "quartz latite" on the basis of chemical analyses from petrographically similar lavas in the NTS region.

Brecciation is common within the quartz latite lava, though not as intense as within the overlying rhyolite lava. The brecciation has given rise to fractures of several scales, smaller veins filled by clay or quartz or lined by albite and filled by quartz, and larger fractures with thick devel(')ment of granular quartz along the fracture walls followed by sparry quartz linings and a final void filling of coarse calcite. Some of the larger fractures and several filled voids have clay as a final authigenic growth rather than calcite. The groundmass between fractures is typically formed of granular quartz-feldspar intergrowths with sparse clay. The clays in the upper $100 \mathrm{ft}(30.5 \mathrm{~m})$ of the quartz latite lava include kaolinite (Fig. 4) as well as the swelling illite/smectites that are more typical of the authigenic clays beneath Yucca Mountain.

Q. Ash Flows (5637 to $5671 \mathrm{ft}, 1718.2$ to $1728.5 \mathrm{~m}$ )

A thin poorly welded crystal-1ithic ash flow of 34-ft (10.4-m) thickness occurs between the quartz latite lava and the lower dacite lava (Fig. 2). The upper $16 \mathrm{ft}(4.9 \mathrm{~m})$ of this ash flow has been reworked and subsequently fused by the overlying quartz latite lava. Although badly altered, the lower part of the ash flow contains about $20 \%$ plagioclase phenocrysts, with less than $3 \%$ each of potassium feldspar and biotite phenocrysts. The plagioclase phenocrysts have altered completely to calcite plus albite; all of the samples from $5650 \mathrm{ft}$ to the bottom of the drill core have suffered the same alteration. 
The biotite phenocrysts have altered completely to colorless, highly birefringent clay (Fig. 7). This clay has a higher potassium content than the clays from shallower levels of the drill core (Table A-IV)

$$
K_{1.7}\left(\mathrm{M}_{0.8}^{2+} \mathrm{Al}_{3.2}\right)\left(\mathrm{Al}_{1.2} \mathrm{Si}_{6.8}\right) \mathrm{O}_{20} \mathrm{OH}_{4} \text {. }
$$

The higher potassium contents of interstratified clays at the bottom of the drill core suggest a higher illite-to-smectite ratio, as is confirmed by $x$-ray diffraction. Accessory phases in the poorly welded ash flow include zircon and abundant coarse apatite. Coarse apatite grains of $n 0.5-\mathrm{mm}$ length occur within glomeroporphyritic clots of plagioclase, biotite, and opaque minerals. 0xidation-exsolution of the Fe-Ti oxide minerals is moderate $\left(C_{4}\right)$. Lithic fragments are abundant $(5 \%$ at $5657-\mathrm{ft}$ or $1724-\mathrm{m}$ depth, to $40 \%$ at $5638-\mathrm{ft}$ or 1718-m depth) and include plagioclase-porphyritic vesicular lavas, trachytic to felty feldspathic lavas, vitrophyric lavas, and relatively minor pyroclastic volcanic fragments with obscure vapor-phase features.

Pumices from the ash flow are completely replaced by granular quart?feldspar intergrowths with foliated clay seams.

The groundmass of the ash

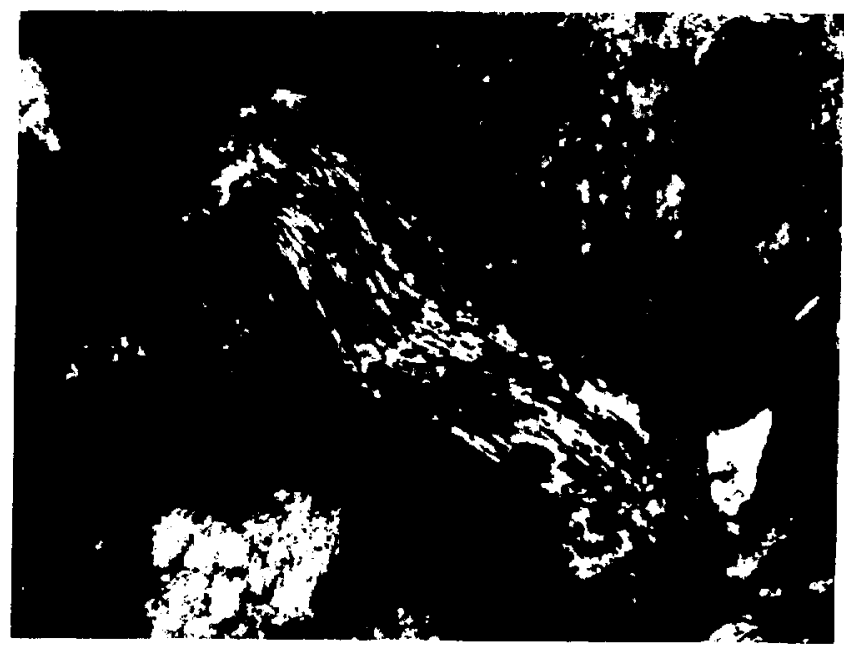

Fig. 7.

Clay crystal, slightly deformed, in an altered ash flow at 5657-ft depth, between the quartz latite and dacite lavas near the bottom of drill core USW-G2. Clay crystals at this depth are exceptionally large, and may have formed by hydrothermal alteration. The field of view is $0.8 \mathrm{~mm}$. See the text for discussion of clays from this depth. 
flow has similar recrystallization textures, although clays within the groundmass may form a polygonal grid-texture. Although chlorite appears in the bulk-rock $x$-ray diffraction studies at 5500-ft $(1676-\mathrm{m})$ depth and can be seen in thin section as a minor alteration of biotite at that depth and at shallower depths, the first occurrence of chlorite as an abundant void-filling mineral is within this thin ash flow at 5657-ft (1724-m) depth (Fig. 4). Chlorite occurs as the final stage of authigenic layer silicate growtit, sealing voids that have wall linings of clay in two-stage growth. This sequence of chlorite crystallization following clay growth is common from here to the bottom of the hole at $6006 \mathrm{ft}(1830.6 \mathrm{~m})$.

R. Dacite Lava (5671 to $5885 \mathrm{ft}, 1728.5$ to $1793.8 \mathrm{~m}$ )

A dacite lava series with associated flow breccias occurs in a 214-ft (65.2-m) interval overlying baked conglomerates near the bottom of USW-G2. The dacite lava is plagioclase-porphyritic (25 to $30 \%$ plagioclase phenocrysts), with minor amounts $(<3 \%)$ of relict amphibole and pyroxene phenocrysts. The mafic phenocrysts are replaced by either calcite or by an intergrowth of chlorite plus quartz. The plagioclase phenocrysts are generally altered to albite plus calcite, although one sample $(5820 \mathrm{ft}, 1774 \mathrm{~m})$ has relatively well-preserved plagioclase phenocrysts that retain well-developed normal zonation. These plagioclase phenocrysts have very calcium-rich cores $\left(A n_{80}\right)$. Zircon occurs as an accessory phase. The oxidation-exsolution features in the Fe-Ti oxides indicate restricted oxidation $\left(C_{1}\right.$ to $\left.C_{3}\right)$, similar to the slight oxidation observed in other dense lava flows of the USW-G2 arill core (Fig. 2).

Late-stage authigenic chlorite is abundant in the lower dacite lava. Many void spaces are lined by quartz but filled by a two-stage growth of chlorite. A thick $(1-\mathrm{cm})$ composite vein at $5696-\mathrm{ft}(1736-\mathrm{m})$ depth includes coarse (0.5-cm-1ong) barite crystals between walls of coarse calcite on one side, and of fine-grained quartz on the other (Fig. 8). The occurrence of coarse barite in veins suggests that hydrothermal solutions were involved in the vein filling. Chlorite (Fig. 4) occurs as a late-stage void filling within the vein, just as it does in the groundmass voids of the host lava. S. Baked Conglomerate and Reworked Tuff (5885 to $5942 \mathrm{ft}, 1793.8$ to $1811.1 \mathrm{~m})$ The dacite lava overlies a complex series of volcanic conglomerates, the uppermost of which is baked by the lava flow. Reworked tuffs are interstratified with the conglomerates. The uppermost conglomerate contains 


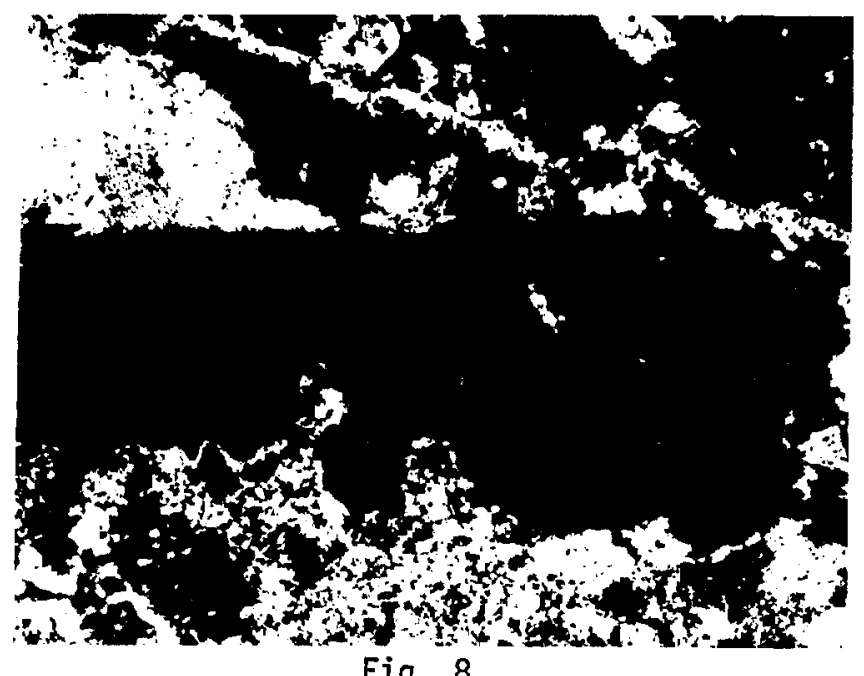

Fig. 8.

Large barite crystal (gray) from a composite calcite-quartz-barite vein at 5696-ft depth, within brecciated dacite lava. The field of view is $3.3 \mathrm{~mm}$.

approximately $80 \%$ matrix of a probable silty origin, now recrystallized to a coarse patchy intergrowth of feldspar plus clay. Relict pebbles in the conglomerate are primarily plagioclase (12\%, now completely replaced by calcite), with fewer reict pebbles of quartz, ash flow tuff, and feldspathic lavas ( $<2 \%$ each). The reworked tuffs are very poorly preserved. The tuffs contain phenocrysts of quartz, potassium feldspar, and plagioclase that has generally altered to calcite plus clay. Zircon, relict sphene, and rare apatite occur as accessory minerals. 0xidation of the Fe-Ti oxides is somewhat advanced beyond the oxidation of the overlying dacite lava $\left(c_{3}\right.$ vs $c_{1}$ to $\left.c_{3}\right)$.

Shards and pumice fragments in the reworked tuffs are replaced by calcite, quartz, feldspar, and clays. Clays may occur as coarse colorless crystals with moderately high birefringence. Clays are mostly distributed throughout the matrices of the conglomerates and reworked tuffs or concentrated within pumices of the reworked tuffs. T. 0lder Ash Flow (5942 to $6006 \mathrm{ft}, 1811.1$ to $1830.6 \mathrm{~m})$

A partially to moderately welded crystal-rich ash flow occupies the bottom $64 \mathrm{ft}(19.5 \mathrm{~m})$ of the USW-G2 drill hole. This ash flow is plagioclaserich ( $8 \%$ plagioclase phenocrysts), with less than $2 \%$ each of quartz, potassium 
feldspar, relict amphibole, and relict biotite phenocrysts. Plagioclase phenocrysts have been replaced by calcite plus albite; where plagioclase phenocrysts abut against veins, the plagioclase have been totally replaced by calcite. Lithic fragments include radial or plumose spherulites and rare trachytic lava fragments. Zircon is abundant as an accessory mineral.

Relict shards are replaced by albite-quartz intergrowths, by calcite, or by albite linings with calcite infilling. Pumices are replaced by calcite, clays, quartz, and albite. Clay crystals may form coarse colorless grains within pumice. Within the clays of this depth the $\mathrm{Fe} / \mathrm{Mg}$ ratio is higher than in clays of the overlying core samples (Table A-IV), although the potassium, aluminum, and silicon ratios show little variation.

This ash-flow tuff was not penetrated in USW-G1 (Fig. 1) and may be older than any units penetrated in hole USW-G1.

IV. PETROGRAPHIC DESCRIPTION OF DRILL HOLE UE25b-1H, FROM $2400 \mathrm{ft}(731.5 \mathrm{~m})$ TO TOTAL DEPTH $4000 \mathrm{ft}(1219.2 \mathrm{~m})$

UE25b-1H is a deeper drill hole north of UE25a-1 (Fig. 1). Our discussion of UE25b-1H begins at a depth of $2400 \mathrm{ft}(732 \mathrm{~m})$ in the Crater Flat Tuff. The section above $2400 \mathrm{ft}$ is covered by descriptions in sykes et al. (1979) and Carroll et al. (1981)(Fig. 9).

A. Bullfrog Member of the Crater Flat Tuff $(2361$ to $2882 \mathrm{ft}, 719.7$ to $878.4 \mathrm{~m})$

Sampling began at $2402 \mathrm{ft}(732 \mathrm{~m})$ in the Bullfrog Member of the Crater Flat Tuff (Fig. 10). Five samples were taken from the Bullfrog and one from the bedded tuff directly beneath it. The Bullfrog in UE25b-1H appears to be a single cooling unit that is first intersected in the upper zone of partial welding. The section is more densely welded with depth, then decreases in degree of welding to a non-to-slightly welded basal zone. Vapor-phase alteration is present in the upper samples to a depth of $2596 \mathrm{ft}(791 \mathrm{~m})$. Phenocrysts are most abundant in the uppermost sample at 2402-ft, (732-m-depth), comprising 15 to $20 \%$ of the total rock. The other samples contain only 3 to 7\% phenocrysts. Phenocryst phases are embayed quartz, alkali feldspar, plagioclase, biotite, opaque oxides, and pseudomorphs after hornblende. Pseudomorphs after pyroxene occur in the uppermost sample. Lithic fragments are sparse, forming $\leq 1 \%$ of the rock in all samples but one (2737-ft, 834-m depth) where they form $3 \%$ of the rock. Pumice pyroclasts form 10 to $30 \%$ of the rock. 


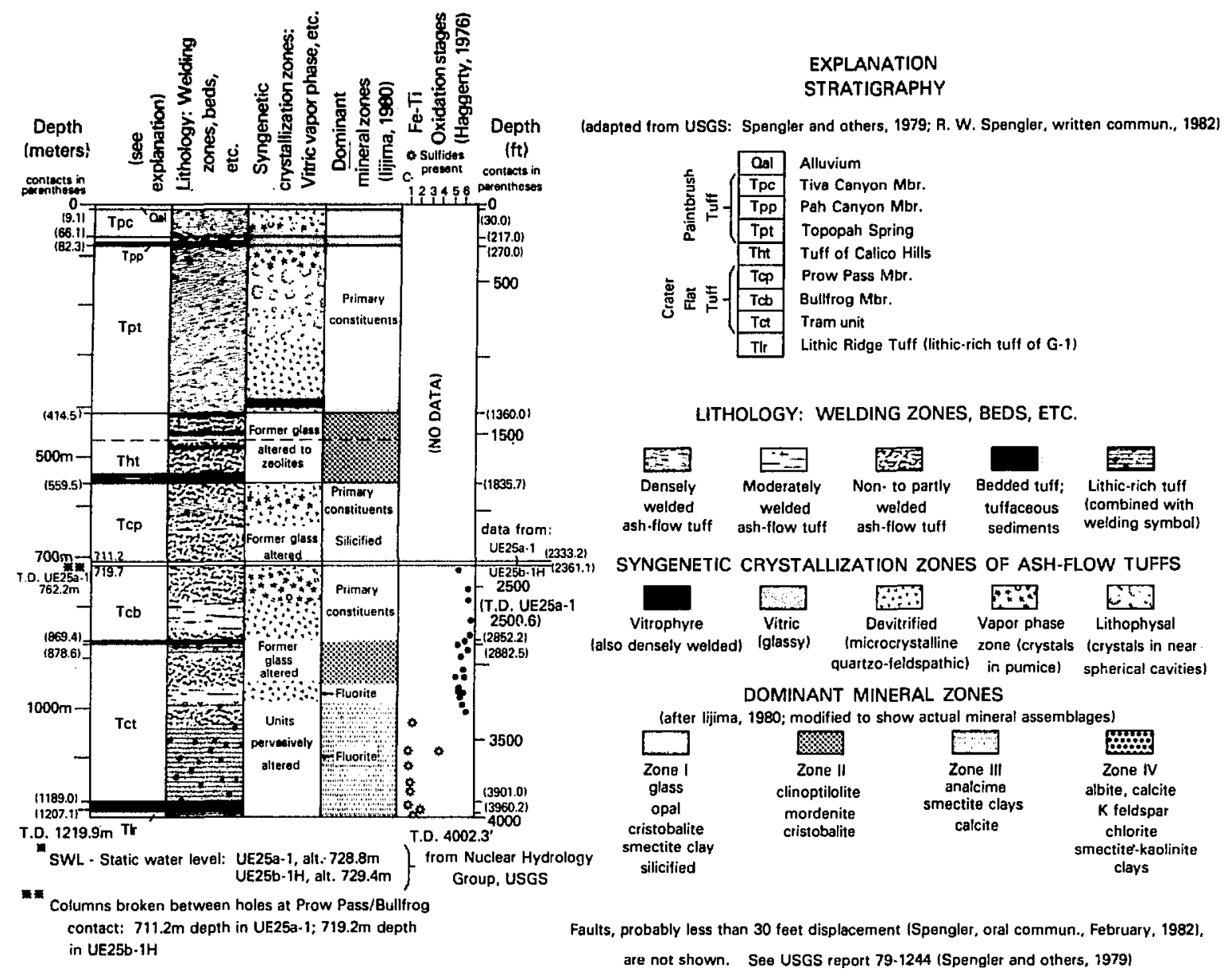

Fig. 9.

Stratigraphy of primary and seconfary petrographic features from the combined data of drill holes UE25a-1 and UE25b-1H. Faults, probably with less than $30-\mathrm{ft}(9.1-\mathrm{m})$ displacement (R. Spengler, USGS, personal communication, 1982) are not shown. For additional discussion of the stratigraphy in drill hole UE25a-1 refer to Spengler et al. (1979).

0xidation numbers for the Bullfrog are rather high $\left(C_{6-7}\right)$ (Fig. 9). For the upper samples down to $2596-\mathrm{ft}(791-\mathrm{m})$ depth the oxidation is probably the result of vapor-phase reactions. The lowest ash flow and the bedded tuffs below may be highly oxidized as a result of greater porosity (slight welding or no welding). However, one sample with highly oxidized Fe-Ti oxides $\left(C_{7}\right)$ occurs at $2737 \mathrm{ft}(834 \mathrm{~m})$. Because this is the most densely welded sample, it is anomalous that this sample is the most oxidized. It is notable that in this sample the reddish brown shards stand out against the pale groundmass. 


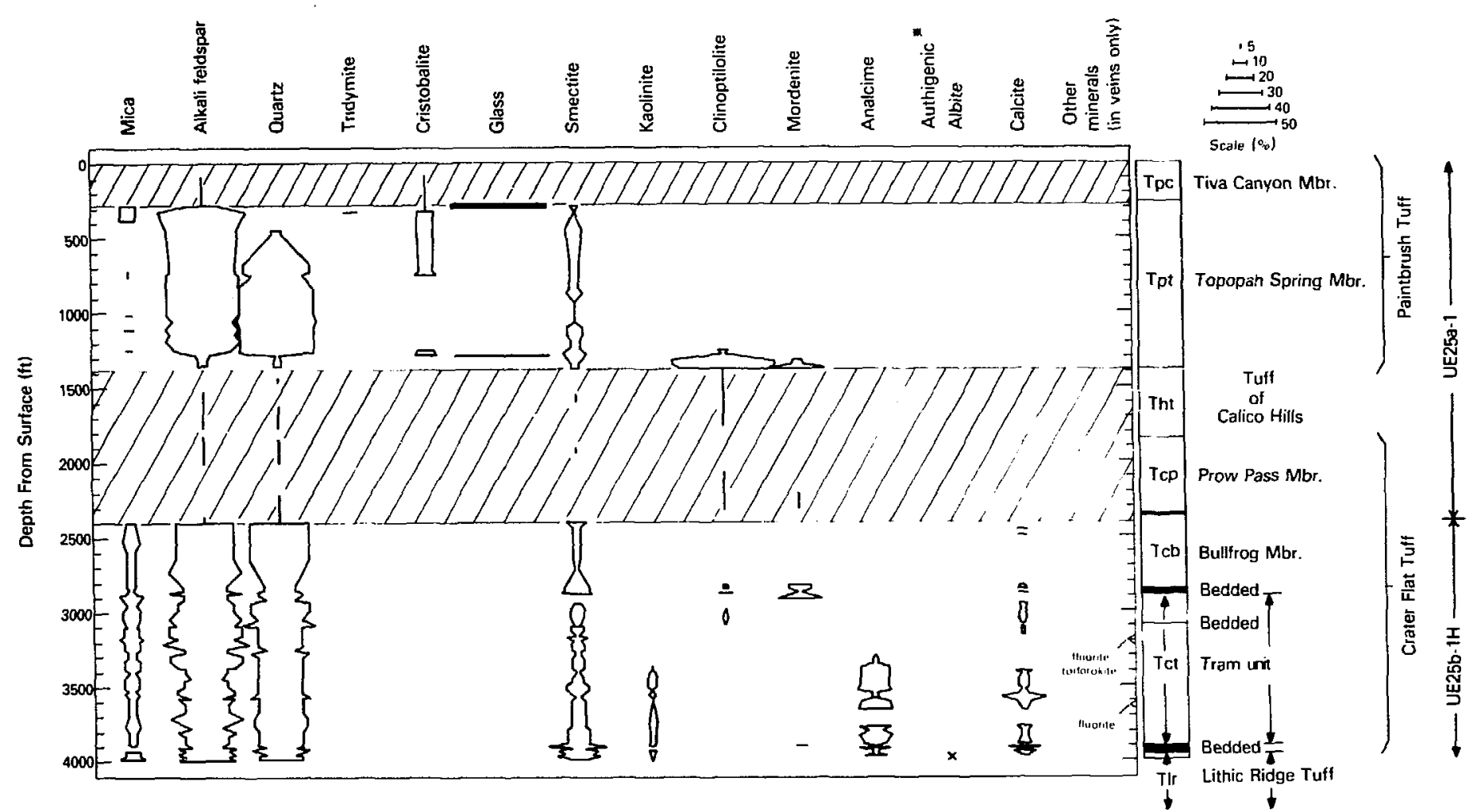

Fig. 10 .

Mineral and glass abundances in drill holes UE25a-1 (to $2400 \mathrm{ft}$, or $731.5 \mathrm{~m}$ depth) and UE25b-1H (from $2400 \mathrm{ft}$ to T.D.). Quantitative data are available only for the Topopah Spring Member of the Paintbrush Tuff in drill hole UE25a-1 (Carroll et al. 1981). Data from $2400 \mathrm{ft}$ to T.D. in drill hole UE25b-1H were prepared for this report and are listed in Table III. The scale in the upper right of this figure can be used to estimate relative volume percentages except within the hachured regions, where data are not quantitative. Continuous vertical lines within the hachured regions represent identified occurrences without implying any relative abundances (see Sykes et al. 1979). Occurrence of authigenic albite at the bottom of UE25b-1H was determined optically. 
This is apparently the result of iron oxidation in the original glass. Zeolites occur in the lowest unit (2832 ft, $863 \mathrm{~m})$, which is only slightly welded. Clinoptilolite and mordenite predominate. Clinoptilolite forms euhedral crystals growing within void spaces (Fig. 11), whereas mordenite is apparently restricted to the microcrystalline groundmass.

The bedded tuff below the ash flow contains abunciant phenocrysts and lithic fragments. Clays within the groundmass obscure the original textures. $x$-ray diffraction studies indicate that clinoptilolite and mordenite are abundant (Fig. 10), but large crystals of these minerals were not identifiable and the groundmass could not be analyzed by microprobe. Zeolite analyses are summarized in Fig. 12.

B. Tram Member of the Crater Flat Tuff (2882 to $3901 \mathrm{ft}, 878.4$ to $1189.0 \mathrm{~m}$ )

The Tram Member of the Crater Flat tuff is slightly thicker at this location than in arill hole USW-G1. In USW-G2 the Tram was penetrated from depths of $2882 \mathrm{ft}(878 \mathrm{~m})$ to $3901 \mathrm{ft}(1189 \mathrm{~m})$ for a total thickness of $1019 \mathrm{ft}$ $(310.6 \mathrm{~m})$. On the basis of field descriptions (Spengler, USGS, personal communication) and petrographic analyses, this member of the Crater Flat tuff has been divided into two subunits: an upper, welded-to-moderately welded, generally brownish-gray devitrified tuff, and a lower, nonwelded, hydrothermally altered, greenish-gray tuff, characterized by sparse pyrite and low-oxidation stage (Fig. 9). Within the upper subunit is a bed of tuffaceous sandstone $1 / 2 \mathrm{ft}$ thick.

1. Upper Tram Subunit (2882 to $3360 \mathrm{ft}, 878.4$ to $1024.1 \mathrm{~m}$ ). The upper Tram subunit consists of a sequence of moderately to densely welded ash flow tuffs. Many of the upper and lower contacts of these flows are gradational (Spengler, personal communication) and, in one case, thinly laminated beds at an angle of $5^{\circ}$ to the borehole appear to be a ground surge deposit associated with one of the pyroclastic flows.

By volume, 15 to $20 \%$ of the upper subunit consists of phenocrysts. The most common phenocryst type is plagioclase up to $3 \mathrm{~mm}$ long $\left(A n_{20} A b_{75}{ }^{0} r_{5}\right.$ to $\mathrm{An}_{38} \mathrm{Ab}_{59} \mathrm{Or}_{3}$ ) although most are in the $0.7-$ to $1.2-\mathrm{mm}$ size range. Nearly all plagioclase phenocrysts are crossed by multiple, irregular, thin fractures, filled with smectites and calcite. In lesser amounts are phenocrysts of quartz, sanidine, biotite, and Fe-Ti oxides. Also, in the lowest two-thirds of this subunit are traces of allanite. Subhedral, unzoned, 0.4- to 3-mm-long sanidines $\left(A n_{1} A b_{33} O r_{66}\right)$ are, in a few cases, crossed by multiple fractures 


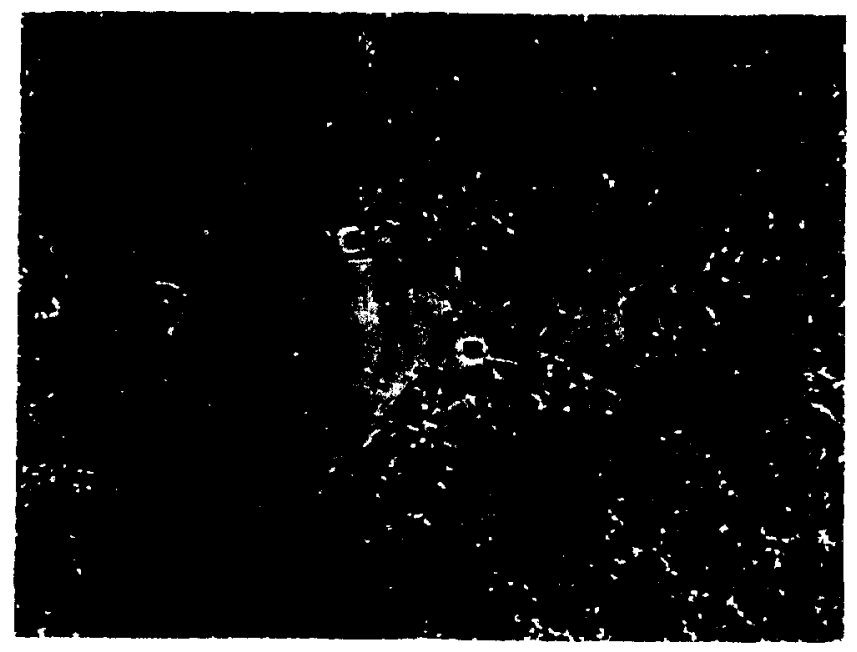

Fig. 11.

Void partially filled by clinoptilolite crystals. These blocky, tabular forms are a common morphology for clinoptilolite. The void may have been produced by dissolution of a shard. Groundmass around void is primarily clinoptilolite with minor quartz. Sample UE25b-1H 2832, plane light. Field of view is 0.27 mm.

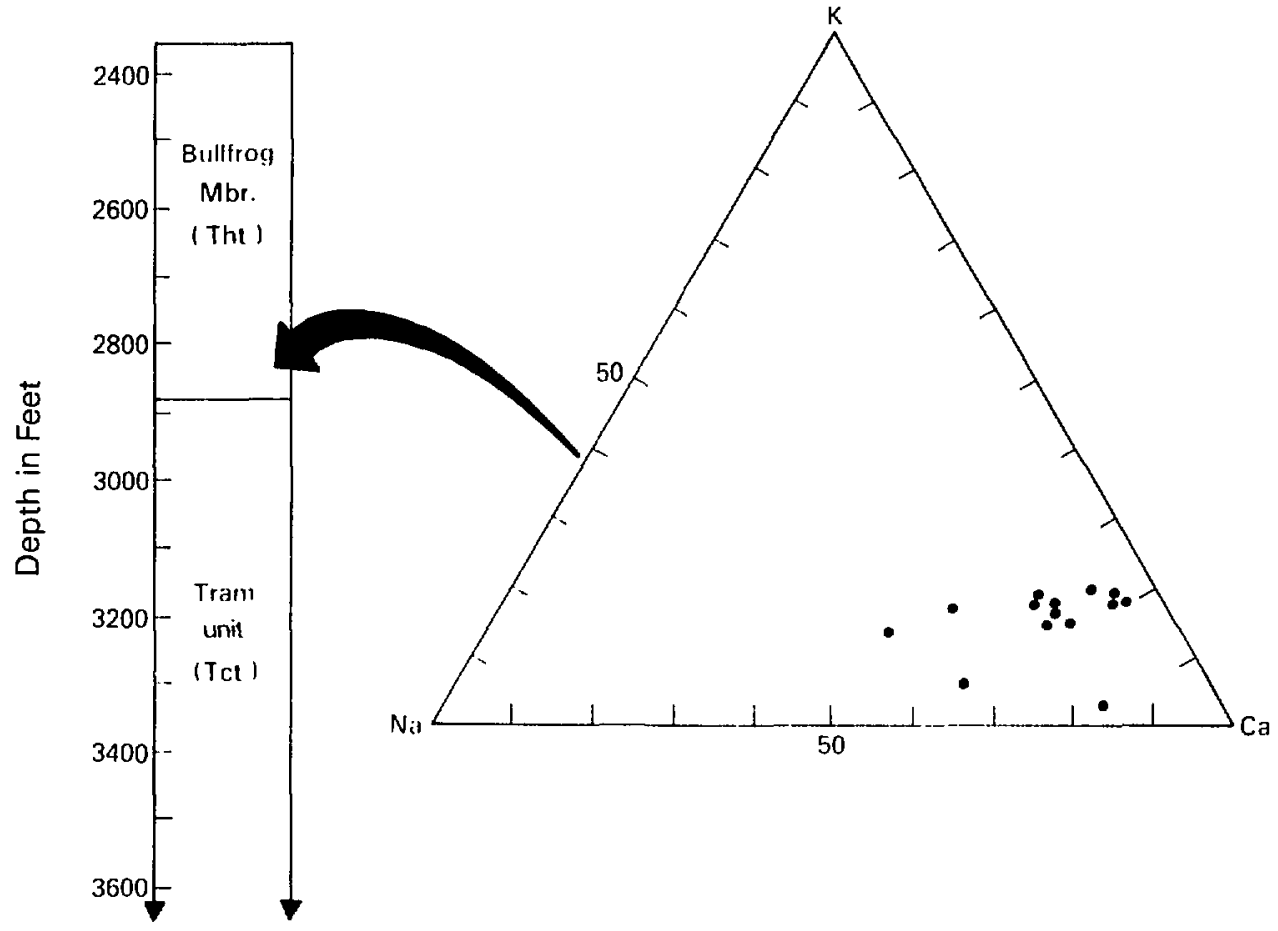

Fig. 12 .

Cation compositions in the projection $\mathrm{K}-\mathrm{Na}-\mathrm{Ca}$ for zeolites in the bedded tuff under the Bullfrog Member in drill hole UE25b-1H. 
filled with clay. Quartz is present as equant, subhedral, rounded (partly resorbed) phases, 0.3 to $3 \mathrm{~mm}$ in diameter. Biotites 0.3 to $1.5 \mathrm{~mm}$ long are oxidized to very dark brown. Most biotites are oriented parallel to the fabric of the welded tuffs. In some cases these tattered biotite flakes are deformed by other pyroclasts. Fe-Ti oxides have medium- to high-oxidation states ranging from $C_{5}$ to $C_{6}$, which characterizes this subunit (Fig. 9). Highly pleochroic, reddish-brown allanite is present as subhedral to euhedral phenocrysts up to $0.4 \mathrm{~mm}$ long. It is only present in trace amounts but is a very distinctive signature for the lower part of this subunit.

Lithic fragments in this subunit make up less than $5 \%$ to nearly $10 \%$ of the samples analyzed. Within the upper half, the lithic fragments consist of older tuffs (subrounded fragments of 1 to $2 \mathrm{~mm}$, with occasional grains as large as $4 \mathrm{~mm}$ ). In the lower half, there are mostly subrounded, equant to slightly elongate lava fragments, characterized by glomeroporphyritic clots of plagioclase in a groundmass with faint relict flow structure. There are also older tuff fragments, some with spherulitic textures.

The matrix in this unit usually makes up approximately $80 \%$ of the rock and consists of relict pumice pyroclasts, relict shards, and finely crystalline phases that have filled all space available between the pyroclasts. Relict pumices usually make up between 40 and $50 \%$ of the matrix. Most are oriented, slightly compacted, elongate tattered relicts 1 to $6 \mathrm{~mm}$ long and 0.5 to $2 \mathrm{~mm}$ wide. Most are slightly deformed by adjacent phenocrysts or lithic fragments. As in other tuffs of this sequence, relict forms have been preserved along pyroclast edges by trains of $<1 \mu \mathrm{m}$ hematite grains, consistent with the high-oxidation state of the unit (Fig. 9). The glass within pumice pyroclasts has been replaced by spherulitic bundles of 2 to $4 \mathrm{\mu m}$ wide, 30 to $50 \mathrm{\mu m}$ long colorless to pale-brown phases. These fibrous phases consist of authigenic quartz, authigenic alkali-feldspar, and zeolites. In the lower half of the subunit, relict pumices are replaced by light-brown to colorless granular phases, $40 \mu \mathrm{m}$ to $1 \mathrm{~mm}$ in diameter (smectites); the centers of some pumices have been dissolved, leaving void space now filled with smectites and/or coarse anhedral colorless phases (cristobalite or tridymite and authigenic $K$-feldspar and authigenic quartz) or phases with well-developed tabular habits growing into the void. Some of the voids are partly filled by medium-brown fibrous phases in curving (botryoidol?) masses. Scattered 
throughout are traces of finely crystalline hematite. Most pumice pyroclasts contain the same assemblage of phenocrysts described earlier.

Oriented, slightly deformed shards, $30 \mu \mathrm{m}$ to $300 \mu \mathrm{m}$ long are present in all samples. The glass has been replaced by the same phases found in the pumice pyroclasts: fibrous, spherulitic phases in the upper half and finely crystalline equant phases for the lower half of the subunit. These phases include authigenic quartz and alkali-feldspar and silica phases. In the lower half of the subunit, relict shards are difficult to identify. The space between shards is filled with finely crystalline $(3$ to $30 \mu \mathrm{m})$, equant, light-brown to colorless phases. These consist of mixtures of authigenic alkali-feldspar and silica [quartz and cristobalite(?)], zeolites, cristobalite, and smectites.

Within the upper part of this Tram subunit, a sample was taken from a finely laminated bedded tuff at a depth of $3093 \mathrm{ft}(943 \mathrm{~m})$. This sample was originally a vitric-crystal tuff, similar in most ways to the welded ash-flows above and below it but different in that it has sloping, crudely graded beds, 1 to $3 \mathrm{~mm}$ thick, consisting of mostly relict shards. No relict pumice pyroclasts were seen. Phenocryst assemblages and secondary minerals are similar to those above and below with the exception of well-preserved relict shards. The relict shards have been replaced by zeolites.

2. Lower Tram Subunit ( 3360 to $3901 \mathrm{ft}, 1024.1$ to $1189.0 \mathrm{~m}$ ). The lower Tram subunit is a greenish-gray, nonwelded, altered lithic tuff with a total thickness of $541 \mathrm{ft}(165 \mathrm{~m})$, containing layers of lithic tuff and tuffaceous sandstone. It is easily distinguished from the upper Tram by highly inflated pumices and shards, which are very well preserved as relicts. The unit is characterized by sparse disseminated pyrite and a very low-oxidation state (Fig. 9).

This unit is characterized by 7 to $15 \%$ phenocrysts, including sanidine, plagioclase, quartz, biotite, Fe-Ti oxides, and allanite. Sanidine occurs in two forms; 0.5- to 1.5-mm diam, equant, slightly resorbed and tabular, up to 3mm-long crystals. In this nonwelded unit, the Fe-Ti oxides are rarely oxidized (Avg. $C_{1}$ ). The 0.3 - to $1.0-\mathrm{mm}$-long plagioclase phenocrysts exhibit oscillatory zoning ( $\mathrm{An}_{14} \mathrm{Ab}_{78} \mathrm{Or}_{8}$ to $\mathrm{An}_{40} \mathrm{Ab}_{56} \mathrm{Or}_{4}$ ); many are altered, and crossed by veins filled with clays and calcite. Most quartz phenocrysts have been broken into subhedral chips with lengths of up to $1 \mathrm{~mm}$. As in the upper Tram subunit, biotite is present as ragged, oxidized forms up to $1.5 \mathrm{~mm}$ long. 
Allanite is present only in trace amounts as euhedral crystals with a maximum length of $400 \mu \mathrm{m}$.

Actual percentages of lithic fragments were hard to assess in the cores due to a range of sizes from less than $0.5 \mathrm{~mm}$ to larger than the size of the thin sections. Estimates range from 25 to $40 \%$ within the subunit. The two most common types of lithic fragments are subrounded to subangular, slightly elongate welded tuffs and aphanitic rhyolitic lavas; and pilotaxitic intermediate lavas. Textures within the older welded tuffs of the lithic fragments are poorly preserved as the bulk of these fragments have been replaced by smectites, calcite, and a silica phase. Some of the lithic fragments have voids within them filled with well-developed chlorite sheaves.

Dominating the matrix are highly inflated pumice and shard relicts. About $85 \%$ of the volume of these pyroclasts consists of vesicles. Pumice pyroclasts with diameters in the range of 2 to $4 \mathrm{~mm}$ contain 2-mm-wide spherical or ovoid vesicles. Vesicle walls are only 10 to $50 \mu \mathrm{m}$ thick. The shards are long, curved forms with two to four cusps remaining from vesicle wall intersections. All of the formerly vitric pyroclasts have been replaced by coarse, colorless phases (10 to $50 \mathrm{\mu m}$ ) characterized by their very low birefringence; those analyzed consist of analcime.

Space between pyroclasts has been filled with finely crystalline ( 3 to 20 $\mathrm{mm}$ ) phases, including:

(1) colorless phase with low birefringence and high relief in reflected light, consisting of authigenic alkali-feldspars, silica, and some analcime,

(2) medium-brown phases with low birefringence and low relief in reflected light (smectites),

(3) sub-1 $\mu \mathrm{m}$, equant, grains of hematite, and

(4) pale-green phases (some up to $30 \mu \mathrm{m}$ long) with a fibrous appearance (chlorite).

All of the phases listed above are intergrown and sometimes appear as irregular patches throughout the matrix. Within the lower part of this subunit, the matrix contains 3 to $5 \%$ subhedral to euhedral pyrite grains in the size range of 1 to $30 \mu \mathrm{m}$ and irregular patches of sparry calcite cement.

One unit, sampled at a depth of $3571 \mathrm{ft}(1088.4 \mathrm{~m})$, is an immature tuffaceous volcanic arenite. It consists of 7- to 250-4m silt and sand grains in a low relief, pale-brown matrix (smectites). The variety of sand grains 
includes subrounded to subangular quartz; welded tuff and subrounded spherulite fragments; subangular to subrounded sanidine; aphanitic lavas (groundmass completely replaced by smectites); subangular, equant plagioclase; Fe-Ti oxides; and angular to subangular allanite.

Many of the samples from this subunit were chosen for the purpose of examining filled fractures at depths of $3506 \mathrm{ft}(1068.6 \mathrm{~m}), 3571 \mathrm{ft}(1088.4$ $\mathrm{m}), 3660 \mathrm{ft}(1115.6 \mathrm{~m})$, and $3708 \mathrm{ft}(1339 \mathrm{~m})$. The uppermost sample (3506- $\mathrm{ft}$, 1068.6-m depth) is crossed by a very thin network of thin calcite-filled veins. The two lower examples are crossed by well-developed, $0.5-\mathrm{mm}$ to $>1-\mathrm{cm}$ fractures. The larger fractures contain angular fragments up to a few millimeters across. Smaller subsidiary fractures cross relict pyroclasts and lithic fragments and some exhibit lateral offsets of a few millimeters. These fractures are filled with sparry calcite consisting of interlocking crystals of up to $4 \mathrm{~mm}$ long. In a few cases, plumose growths of calcite have grown inward from fracture walls. Some of the voids not filled with calcite are filled with well-developed, $0.5-\mathrm{mm}-1$ ong euhedral zeolite phases (clinoptilolite and mordenite) and authigenic silica (Appendix Fig. B-8). In instances where the calcite is iractured, the fractures are filled with smectites and irregular elongate patches of chlorite. It appears that there was, to some extent, slight movement and shearing before these fractures were filled.

C. Bedded Tuff Between the Tram Member of the Crater Flat Tuff and the Lithic Ridge Tuffs (3901 to $3960 \mathrm{ft}, 1189.8$ to $1207.8 \mathrm{~m}$ ).

The sample from this unit is a moderately welded vitric crystal tuff. It is very similar petrologically to the underlying Lithic Ridge Tuff.

This unit is characterized by 15 to $20 \%$ phenocrysts, including plagioclase, K-feldspar, Fe-Ti oxides, and biotite. Plagioclase is present as mostly subhedral, $140-\mu \mathrm{m}$ to $4.0-\mathrm{mm}-1$ ong forms; about $25 \%$ exhibit oscillatory zoning. Anhedral K-feldspars, 80- $\mu \mathrm{m}$ to $600-\mu \mathrm{m}-1$ ong, are, in some instances, partly replaced by calcite. Like most tuff units in this stratigraphic section, biotite is oxidized, as are the ragged Fe-Ti oxides $\left(C_{2}\right)$. The largest Fe-Ti oxides $(600 \mu \mathrm{m}$ to $2 \mathrm{~mm}$ ) are associated with glomeroporphyritic clots consisting of biotite, Fe-Ti oxides, and plagioclase. Lithic fragments are mostly subrounded, orange-brown or light-brown vitric or vitric-crystal tuffs, $600 \mu \mathrm{m}$ to $800 \mu \mathrm{m}$ long that make up only $5 \%$ of the rock.

Nearly half of the matrix consists of 3- to 6-mm-long, 0.5- to 2-mm-wide relict pumice pyroclasts. Most of the pumices have been compacted and are 
deformed when in contact with a phenocryst or lithic fragment. These pumices have been replaced by colorless to palembrown, micaceous phases with high birefringence; each is about $1 \mu \mathrm{m}$ wide and 10 to $30 \mu \mathrm{m}$ long.

The fine-grained matrix consists of nearly equal amounts of colorless, equigranular phases, 3 to $10 \mu \mathrm{m}$ in diameter and pale-brown, micaceous phases. Only faint outlines of a few relict shards are preserved. D. Lithic Ridge Tuff (3960 to $4002.3 \mathrm{ft}, 1207.8$ to $1220.7 \mathrm{~m})$.

The sample from $3988 \mathrm{ft}(1227 \mathrm{~m})$ is a moderately welded vitric-crystal tuff. Most of the tuff has been replaced with secondary minerals and only rarely are relict pyroclasts visible.

The phenocryst assemblage, consisting of plagioclase, K-feldspar, Fe-Ti oxides and biotite, makes up about $20 \%$ of the rock. Plagioclase phenocrysts are mostly subhedral, $200 \mu \mathrm{m}$ to $3.1 \mathrm{~mm}$. Most of these exhibit oscillatory zoning. Equant, oxidized Fe-Ti oxides $\left(C_{2}\right)$ and biotite are present in small amounts.

Lithic fragments (5\%) consist of mostly subrounded, 90 to $200 \mu \mathrm{m}$ long, crystal-vitric tuffs; most have been replaced by equigranular pale-brown phases. There are also traces of oxidized porphyritic lava.

The welded fabric is only visible due to relict, compacted pumice pyroclasts, which make up $20 \%$ of the matrix. The pumices have been replaced by dark-brown, fibrous phases with medium birefringence (low relief in reflected light), which are probably smectites. The pumice pyroclasts are 3 to $4 \mathrm{~mm}$ long and 300 to $500 \mu \mathrm{m}$ wide. Some contain the whole assemblage of phenocrysts described above.

The finer-grained matrix consists of a mixture of equigranular, colorless phases with high relief in reflected light- and medium-brown fibrous phases, which are most likely smectites in zones 3 to $10 \mathrm{\mu m}$ wide. Scattered throughout the matrix are 30- to 100-um-iong ragged, zoned patches, consisting of rims of colorless phases and cores of pale-green equigranular chlorite (?).

V. SUMMARY: COMPARISON OF USW-G2 AND UE25b-1H AND RELATIONS TO OTHER DRILL HOLES AT YUCCA MOUNTAIN

The objective of examining the silicic tuffs of Yucca Mountain is to locate a horizon or horizons suitable for radioactive waste disposal. The best combination is twofold; a thick densely welded unit that has a high thermal conductivity and a nearby effective zeolitized horizon (preferably 
clinoptilolite or mordenite) to act as a natural barrier to radionuclide migration. An important adverse effect is that densely welded zones may have high fracture permeability. A second option would be to site the repository in a thick zeolitized horizon. The drawback in this case is that thermal loading must be kepr at a minimum (see Bish et al. 1981). With this purpose in mind, we will compare the two most recent drill cores (USW-G2 and UE25b-1H) from the NTS and correlate these with previous drill cores (USW-G1 and J-13).

\section{A. Upper Members of Paintbrush Tuff}

The upper portion of the Paintbrush Tuff consists of the following Members; Tiva Canyon, Yucca Mountain, a bedded tuff, and the Pah Canyon. All four Members are present in the USW-G2, whiie only the Tiva Canyon Member is present in UE25a-1 (near UE25b-1H). All of the upper Paintbrush units thin from the northwest to the southeast and pinch out between the USW-G1 and UE25 drill holes except the Tiva Canyon. Furthermore, the Tiva Canyon is missing in USW-G1 (Fig. 13). Of these upper members of the Paintbrush Tuff, zeolites are present only in the Pah Canyon Member of the USW-G2 core.

B. Topopah Spring Member of Paintbrush Tuff

The Topopah Spring Member of the Paintbrush Tuff in arill hole USW-G2 is composed of a compound cooling unit (Lipman 1966), consisting of two discrete units. From bottom to top, the lower unit consists of a basal nonwelded zeolitized portion overlain by a vitrophyric to densely welded, zeolitized interval and finally a thick (700 ft or $213 \mathrm{~m}$ ) sequence of moderate-to-densely welded, devitrified, vapor-phase altered ash-flow tuff. The upper unit (759 to $906 \mathrm{ft}$ or 231 to $276 \mathrm{~m}$ ) ranges from nonwelded and zeolitized at the top, downward to an unaltered vitrophyre, in turn underlain by a densely welded, devitrified, vapor-phase altered ash-flow base.

No significant break (air fall) between cooling units was found in hand samples of the drill core. However, the partial petrologic and cooling break described near $906 \mathrm{ft}(276 \mathrm{~m})$ is based on two observations: first, the absence of clinopyroxene phenocrysts below $906 \mathrm{ft}$ and second, the variation in degree of welding from 898 to $951 \mathrm{ft}(273$ to $290 \mathrm{~m})$. If this were one simple cooling unit in this proximal location, no variation would have appeared. Instead, samples at $951 \mathrm{ft}(290 \mathrm{~m})$ are moderately welded, whereas the overlying samples are densely welded. It is believed that the lower unit was emplaced and already starting to cool (hence only moderate welding at $951 \mathrm{ft}$ ) when the upper unit was erupted. Due to the high temperature of the quartz 


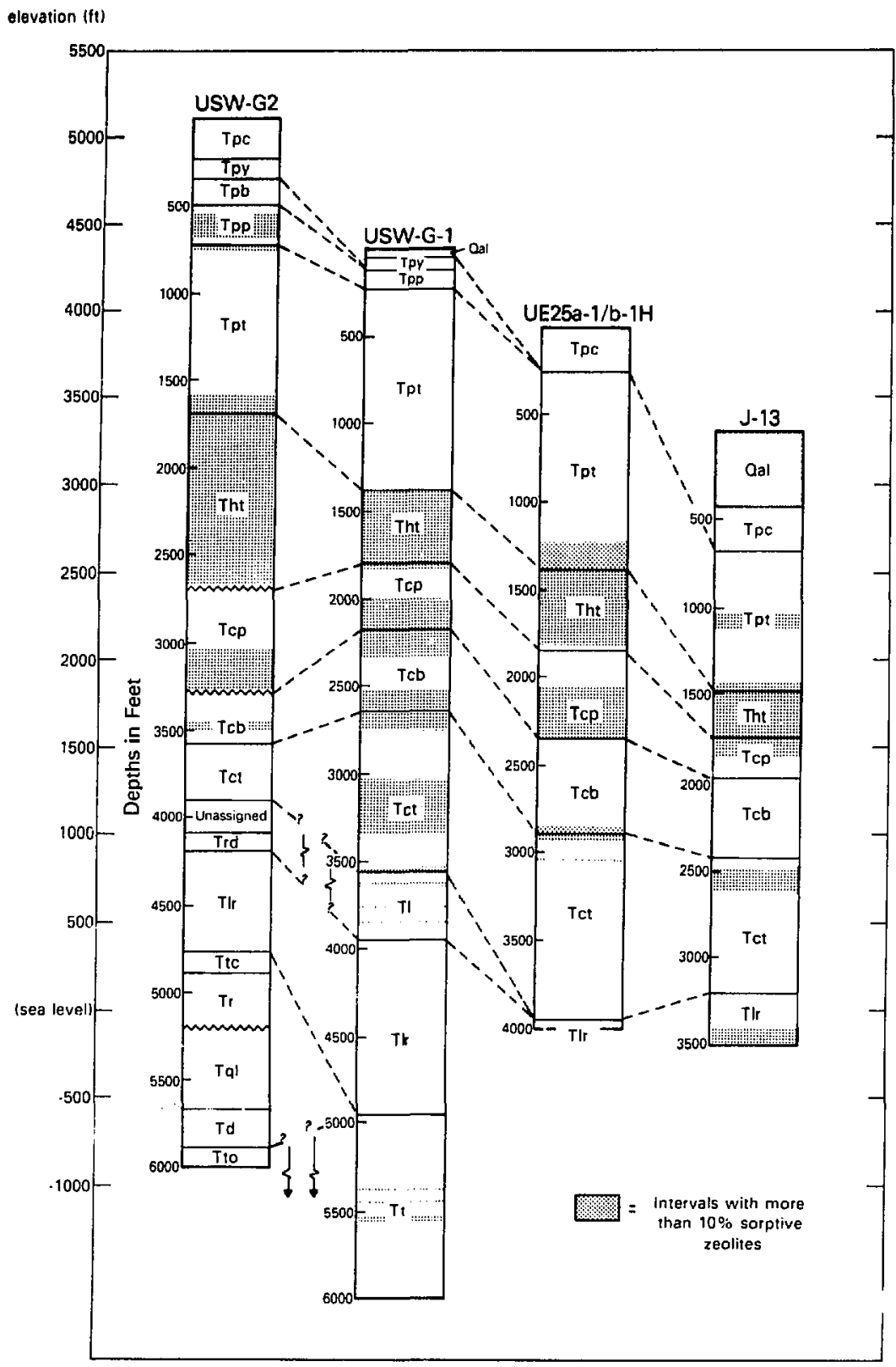

Fig. 13.

Comparative stratigraphies of drill holes USW-G2, USW-G1, UE25a-1/b-1H, and J-13 normalized is a common base-level. Intervals of sorptive open-channel zeolite occurrences in excess of $10 \%$ by volume are indicated for each drill hole. Symbols used for stratigraphic units are defined in Fig. 2, with the addition of Qal (Quaternary alluvium), Tfb (dacite flow breccia of USW-GI), and Tt (older tuffs of USW-íl). 
latite eruption, the underlying cooling unit was sintered and welded. This is the same eruptive sequence described in Carroll et al. (1981) for the Topopah Spring. At distal edges a complete cooling break may occur, which would make the Topopah Spring a composite sheet.

Vapor-phase abundance in the USW-G2 drill core of the Topopah Spring is similar to cores of all the other drill holes. Immediately above the lower vitrophyre, vapor-phase alteration is very minor. In the overlying densely welded devitrified tuffs, vapor phase is abundant, as are lithophysal cavities. In the overlying moderately welded sample at $951 \mathrm{ft}(290 \mathrm{~m})$, vapor-phase alteration is less abundant. From $921 \mathrm{ft}(281 \mathrm{~m})$ to the base of the upper vitrophyre, vapor-phase alteration is extreme, obscuring many primary textures. Once again, it is believed that the upper vitrophyre acted as a block to concentrate vapor-phase fluids below it, as described in Carroll et al. (1981).

In comparison to other drill cores (USW-G1 and UE25a-1) the thickness of the lower unit below the partial cooling break is approximately the same ( 800 $\mathrm{ft}$ or $244 \mathrm{~m}$ ). The upper part in $\mathrm{G} 2$ is slightly thinner (150 vs $200 \mathrm{ft}$ or 46 vs $61 \mathrm{~m}$ ) than in the USW-G1 and UE25b-1H drill cores. There are other similarities in terms of major lithologies and secondary minerals. All cores contain nonwelded zeolitized basal zones and zeolitized fractures in the lower vitrophyre. The USW-G2 core contains some zeolitization just above the lower vitrophyre. From this point to the top of the upper vitrophyre, all cores consist of devitrified, moderately welded to vitrophyric tuffs composed primarily of the devitrification products cristobalite, tridymite, quartz, and alkali feldspar (for more detail, see Carroll et al. 1981). The only major change is in the partly welded to nonwelded tuffs above the upper vitrophyre. Whereas both the USW-GI and the UE25a-1 cores contain glass in this zone, the USW-G2 core is zeolitized in this interval. The presence of zeolites suggests that the upper vitrophyre of USW-G2 acted as an impermeable barrier at one time and possibly created a local perched water table.

Two other differences within the Topopah Spring Member are apparent in the J-13 drill core. Most obvious is the lack of the upper compound cooling unit. The lower cooling unit is petrographically very similar to other cores, but it is bounded on the top by a thick soil horizon. The possibility exists that the upper cooling unit of the Topopah Spring was eroded away at the J-13 drill site. Second, a possible thin zeolite horizon is present near the 
center of the densely welded lower cooling unit. Heiken and Bevier (1979) described a zone of zeolitization over a $90-\mathrm{ft}$ interval near the center of the Topopah Spring Member. The sporadic occurrence of zeolites in the body of the J-13 core and above the lower and upper Topopah vitrophyres of USW-G2 poses a slight problem. One may not be able to pick one part of the Topopah Spring Member "a priori" for a repository and assume that it has no zeolites. Any possible repository horizon must be thoroughly scrutinized for the presence of zeolite beds that have low thermal stabilities.

Fractures in the middle densely welded portion between the two vitrophyres of the USW-G2 core may present problems if this horizon is considered as a possible waste repository site. As reported earlier, the three main types of fractures are (1) open, (2) filled by silica, or (3) filled by calcite. The oldest fractures are those filled by silica phases. These fractures are probably contraction fractures formed during cooling of the ash flows and filled by vapor-phase crystallization. The calcite veins may well be of intermediate age. Analyses of uranium-thorium disequilibrium in two calcite-filled fractures in the Topopah Spring Member of USW-G2 give minimum ages of 130000 and 400000 years (R. Spengler, USGS, personal communication, 1982). The open fractures are certainly younger than the silica filled fractures (cross-cutting relations) and do not appear to be of the same generation as the calcite-cemented faults. If the open fractures were older than or contemporaneous with the calcite filled faults, then the open fractures would probably contain calcite (calcite is pervasive in the samples where it is seen). Because calcite is never seen within the open fractures, these fractures are probably youngest. It is possible that the open fractures formed recently and have not had time to seal.

Two questions must be considered if the Topopah Spring Member is considered as a possible waste repository horizon. First, is it possible that downward percolation of meteoric water no longer occurs at the Yucca Mountain block? If downward percolation is occurring, why are the young open fractures not filled by calcite and/or clays? Apparently the upper vitrophyre no longer acts as a barrier, for it also contains open fractures. Second, is it possible that the region is still tectonically active and producing features such as the open fractures of the Topopah Spring Member? 
The Tuff of Calico Hills below the Topopah Spring Member is the only completely zeolitized major tuff unit in all arill cores yet examined at Yucca Mountain. The Calico Hills unit is typically 400 to $500 \mathrm{ft}$ (123 to $152 \mathrm{~m}$ ) thick in all the drill holes except USW-G2. The Calico Hills is nearly 1000 ft $(305 \mathrm{~m})$ thick at this site (Fig. 13). Clinoptilolite is the only zeolite identified within the Calico Hills unit in USW-G1. In USW-G2 both clinoptilolite and mordenite are important zeolite phases in this unit., Factors responsible for the appearance of mordenite in USW-G2 and its absence in USW-G1 $2.6 \mathrm{~km}$ to the south are not fully understood. The presence of mordenite in the upper phenocryst-poor subunit of USW-G2, which is correlative with the Calico Hills section in USW-Gl, suggests that differences in zeolite mineralogy between the two holes are not due to differences in original bulk chemistry. The first appearance of mordenite in USW-G1 is nearly $1200 \mathrm{ft}$ below the level where it is first noted in USW-G2. If mordenite growth is enhanced at the expense of clinoptilolite at slightly higher temperatures (see following discussion), then it is possible that the geothermal gradient was higher in the USW-G2 site than at the drill hole to the south. The close proximity of USW-G2 to the Clain Canyon-Timber Mountain caldera complex, which closely postdates the Calico Hills tuff may have exposed these rocks to a higher average heat flow near the caldera boundary than rocks further to the south. The chemistry of groundwaters near these calderas might also be affected by a higher temperature regime, particularly if hot water circulated through the originally porous Calico Hills tuff. Oxygen, hydrogen, and sulfur isotopes would be useful in evaluating the temperature characteristics of the groundwaters from which the zeolites precipitated.

There are two ways of incorporating the Calico Hills tuff into the overall waste repository. In one scenario, the Topopah Spring Member could be used as the repository horizon and the Calico Hills tuff would act as a natural ion entrapment column for downward percolating waters in the unsaturated zone. If other geologic and hydrologic conditions were favorable, then location of the repository near the northern end of the Yucca Mountain block where the Calico Hills section is thickest would best complement this repository concept. However, serious attention should be given to the possibility that the zeolitized tuffs would act as an aquitard, forcing downward percolating waters to saturate and move laterally on encountering 
impermeable zeolitic horizons in the Calico Hills tuff. Hydraulic tests in zeolitized tuff, rhyolitic lavas, rhyolite breccia and vitrophyre, and welded tuff on Pahute Mesa show that the lowest permeabilities occur where the principal rock was zeolitized tuff (Blankennagel and Weir 1973). Welded tuff is generally more permeable than zeolitized tuff.

Another scenario involves the use of the Calico Hills tuff as the repository horizon. Again, siting the repository where the target horizon is thickest seems reasonable if no other geologic, hydrologic, or engineering factors eliminate the site. Because fractures are rare in the thin sections examined and, when present, are healed by zeolites, clay, and quartz, the low permeability of the zeolitized tuff should be maintained. The low permeability of the tuff as well as the sorptive capability of the zeolites become important assets in retarding the movement of radionuclides away from the repository. Further study of fracture permeability should probably be conducted in the Calico Hills tuff to verify that potential water passages within the tuff are fully healed.

A critical issue for siting a repository in the Calico Hills tuff is the thermal stability of the zeolite phases, clinoptilolite, and mordenite. Literature dealing with this matter has been summarized by Smyth and Caporuscio (1981). Clinoptilolite may react to analcime (a more dense and less hydrous zeolite phase) under specific conditions at temperatures as low as $105^{\circ} \mathrm{C}$. Can zeolites break down near the repository, remobilize and then reprecipitate in the distal thermal regions, thereby forming a self-sealing package? or would the reaction expell large amounts of water and cause a significant volume decrease of the whole rock mass during the zeolite reaction? This second possibility could open large fractures and produce both a transport medium (the water evolved) and a pathway (the fractures) for the escape of radionuclides.

There is currently no answer as to what will occur by siting a repository in zeolitized tuffs and exceeding an absolute temperature of $105^{\circ} \mathrm{C}$. It is imperative that the possible results be examined and tested in field experiments. A repository sited in zeolitized tuffs might be restricted to in situ temperatures as $10 \mathrm{w}$ as $85^{\circ} \mathrm{C}$ (Smyth and Caporuscio 1981); both experimental and kinetic data are necessary and are being collected to refine our knowledge of zeolite stabilities at Yucca Mountain. 
D. Prow Pass Member of Crater Flat Tuff

This ash flow ranges in thickness from $200 \mathrm{ft}(46 \mathrm{~m})$ in arill hole $\mathrm{J}-13$ to $550 \mathrm{ft}(168 \mathrm{~m})$ in USW-G2 (Fig. 13). Although the Prow Pass Member is thickest in USW-G2, it is bounded at the top and bottom by major faults. Three drill cores (USW-G1, USW-G2, and UE25b-1H) all show a partially to moderately welded, devitrified upper portion varying from 150 to $350 \mathrm{ft}$ (46 to $107 \mathrm{~m}$ ) in thickness. These three drill cores also have a zeolitized lower part ranging from 150 to $300 \mathrm{ft}(46$ to $91 \mathrm{~m})$ in thickness. The core of $\mathrm{J}-13$ contains the thinnest section of Prow Pass (Fig. 13) and is zeolitized in the upper rather than the lower part. Lateral variations in overall thickness and mineralogy indicate that the Prow Pass probably has less favorable characteristics for a repository site than either the overlying or underlying unit. E. Bullfrog Member of Crater Flat Tuff

The thickness of this Member ranges from $300 \mathrm{ft}(91 \mathrm{~m})$ in USW-G2, in which it is bounded by a fault at the top, to a maximum of $550 \mathrm{ft}(168 \mathrm{~m})$ in UE25b-1H (Fig. 13). The Bullfrog Member is also cut by a second major fault in USW-G2, about $60 \mathrm{ft}$ below the bounding fault at the top of the unit. Most significant, however, is the variation in degree of welding and in thickness. The partially to densely welded, devitrified zones range in thickness from 500 ft $(152 \mathrm{~m})$ in UE25b-1H and $J-13$ down to $\backsim 100 \mathrm{ft}(30 \mathrm{~m})$ in USW-G1 and in USW-G2, where faults may have shortened the unit. The zeolite phases also differ between cores. The major zeolite phases in USW-GI and UE25b-1H are clinoptilolite and mordenite, whereas in USW-G2 and J-13 the Bullfrog Member is zeolitized by analcime and mordenite. Besides the variation in zeolite mineralogy, zones of zeolites and their relative position in the Bullfrog are erratic. The zeolite zone in both the $\mathrm{J}-13$ and UE25b-1H cores is located in the lower part of the unit. In USW-Gl, zeolites bound both the top and bottom of the Bullfrog Member. Most unusual is USW-G2, where there is a $50-\mathrm{ft}$ (15.2-m)-zeolite zone approximately $2 / 3$ of the way down in the Bullfrog Member. Another unusual aspect is the occurrence of disseminated sulfides in the lower portion of the Bullfrog Member in USW-G2. The thickness, degree of welding and mineralogy vary radically in the Bullfrog. This variability and the common absence of effective sorptive zeolite barriers suggest that the Bullfrog Member would be an unlikely candidate repository horizon. 
F. Tram Member of Crater Flat Tuff

This ash flow, which underlies the Bullfrog, ranges in thickness from 300 to $1050 \mathrm{ft}(91$ to $320 \mathrm{~m})$. The Tram Member is thickest at arill sites USW-G1 and UE25b-1H but thins to the northwest (USW-G2) and southeast (J-13) (see Fig. 13). In most sections, the Tram is poorly welded with only minor zones of dense welding. One difficulty in assessing the Tram as a potential repository horizon is its variation in petrographic character. Moreover, this unit is poorly welded, and where it is sealed by zeolites its thermal stability may present a problem. The Tram Member in cores USW-G2 and UE25b-1H is practically devoid of highly sorptive zeolites. The central portion of the Tram in USW-G1 is zeolitized to analcime, as is a thin zone near the top of J-13. It would be difficult to predict potential zeolite horizons in the Tram without direct, detailed sampling. Also present as accessory phases in the Tram in UE25b-1H are abundant disseminated sulfides in the groundmass and fluorite in fractures. Variability and sporadic hydrothermal alteration would make characterization of the Tram Member difficult for repository siting.

G. Lithic Ridge Tuff

The Lithic Ridge Tuff has been identified in four drill holes at Yucca Mountain (Fig. 13) but only completely penetrated in the USW-G1 and G2 arill cores. This unit occurs below the stability horizon for sorptive open-channel zeolites in drill holes USW-G2 and UE25b-1H. In these drill holes the only zeolite present is analcime, and this occurs only near the top of the unit. If a repository were located in this unit, assuming that the rock mass has a high thermal conductivity, the thermal stability of sorptive zeolites and heat loading maximums (see discussion of Calico Hills above) become less important. However, the thermal conductivity of the Lithic Ridge Tuff is still unknown. Moreover, the poorly sorptive zeolite analcime, which is common in the upper part of the Lithic Ridge Tuff, would undergo partial water loss under thermal loading.

The great thickness of overlying sorptive minerals would be a suitable barrier to radionuclide migration only under certain conditions. Migration of the radionuclides is heavily dependent on the hydrologic gradient and on the gradient direction. If water transport were lipward (very unlikely) or strictly lateral, then the overlying zeolitized tuffs could form a suitable barrier. Sorptive barriers against lateral transport may occur only if zeolitized horizons are possibly present down dip from a potential horizon (as 
is the case from G2 to G1). If transport of water were downward or through fractures or faults, then the overlying sorptive minerals would not be effective.

In all drill holes, the Lithic Ridge Tuff is poorly welded but well indurated by authigenic feldspars, quartz, and chlorite. In addition, fractures are sealed by calcite and quartz. The Lithic Ridge Tuff is within the stability field of authigenic albite. This zone of alteration may produce a rock that is strong without being brittle. Such a rock would have advantages for mining of a repository and would likely be less susceptible to rock bursts than densely welded devitrified tuffs(A. Waters, Los Alamos National Laboratory, personal communication, 1982), but at present, no rock strength studies have been performed on this unit.

The depth to the Lithic Ridge Tuff is a significant factor affecting its suitability as a repository horizon. Commonly first encountered at about 4000 $\mathrm{ft}$ depth and continuing to $5000 \mathrm{ft}$, the ambient temperature will be high for human working conditions. Geothermal gradients in the USW-GI hole indicate an ambient temperature of approximately $50^{\circ} \mathrm{C}\left(120^{\circ} \mathrm{F}\right)$ at $4000 \mathrm{ft}$. Working temperatures of 120 to $140^{\circ} \mathrm{F}$ can be expected over the depth range of the Lithic Ridge Tuff. Obviously, any large mined facility must be artificially cooled and have a controlled humidity in such an environment.

The Lithic Ridge Tuff has some positive qualities as a potential repository horizon in the saturated zone. There is less need to worry about zeolite thermal stability constraints. The thick sequence of overlying sorptive minerals could provide a reasonable barrier to upward waste element migration provided that these sorptive horizons are encountered where ever deep hydrologic circulation rises to reach the surface and the accessible environment. The possibility of greater rock strength is worth investigation. Critical detractions include the absence of highly sorptive zeolite barriers against lateral and downward water flow, the high ambient temperature at depths of 4000 to $5000 \mathrm{ft}$ in Yucca Mountain, and our current lack of data on the thermal and mechanical properties of the Lithic Ridge Tuff.

H. Dacite, Rhyolite, and Quartz Latite Lava Flows in USW-G2

This series of lava flows is $900 \mathrm{ft}(274 \mathrm{~m})$ thick at the bottom of the USW-G2 drill hole. However, this unit pinches out entirely between USW-G2 and USW-G1. This variation suggests drastic stratigraphic discontinuities at depth in the northern part of Yucca Mountain. Other discontinuities may be 
present below the Lithic Ridge Tuff elsewhere in Yucca Mountain. In addition, barite occurs in a composite vein along with calcite, quartz, and chlorite within the lower pait of the lava sequence in USW-G2. This assemblage is common in epithermal veins of major fluorspar deposits. Because of these gangue minerals, disseminated sulfides, and the presence of fluorite in higher portions of UE25b-1H, the Yucca Mountain block may be positioned atop a heavily mineralized zone. Deeper drill holes can resolve this question.

\section{CONCLUSIONS}

Natural zeolite and clay mineralization is a major justification for siting high-level nuclear waste in tuff. The sorptive capabilities of most open-channel zeolites make these minerals highly attractive as natural barriers against the transport of waste elements from storage canisters; the less sorptive but expandable and more stable smectite clays can reinforce this natural barrier. Regardless of the nuclear activity of the waste that might decay to quite safe levels at the time of release, release is nevertheless inevitable within the scale of geologic time. Zeolites and clays provide natural barriers should premature leakage occur and natural reassurance that the ultimate leakage will be maintained well below acceptable levels of contamination.

Concern about the distribution and the stability of zeolite and clay minerals of Yucca Mountain is justified. The drill holes USW-G2 and UE25b-1H add new dimensions to the previous information from drill holes J-13 (heiken and Bevier 1979), UE25a-1 (Sykes et al. 1979), and USW-G1 (Bish et al. 1981). Several important conclusions can be drawn from this study of USW-G2 and UE25b-1H and from consideration of the total available data from all of these drill holes.

A. The Effective Use of Sorptive Zeolites for Repository Siting

The zeolite minerals with greatest sorptive capacities are those with open-channel frameworks. At Yucca Mountain, the common rock-forming sorptive zeolites are those of the clinoptilalite-heulandite series and mordenite. Previous studies of drill holes from Yucca Mountain have dealt with the stratigraphic distribution of these zeolites; the present study has emphasized not only the stratigraphic distribution but also the distribution of these zeolites on the scale of individual hand-samples. 
In USW-G2, abundant sorptive zeolites occur in the poorly welded or nonwelded tuffs ranging from the bedded tuff above the Pah Canyon Member of the Paintbrush Tuff to the poorly welded upper Tram Member of the Crater Flat Tuff. The mordenite series first occurs at depths below the first occurrence of heulandite-clinoptilolite, and mordenites continue to depths well below the last occurrence of clinoptilolite (Fig. 4). This displacement of the mordenite distribution, generally skewed toward greater depths than the heulanditeclinoptilolite distribution, is common to other drill holes throughout the Nevada Test Site (Hoover 1968). The common repetition of this displacement in tuffs of many different units with differing hydrologic histories suggests that the mordenite series is stable within a higher temperature range than the heulandite-clinoptilolite series. This conclusion is reinforced by current "soak tests" that result in the concomitant degradation of euhedral clinoptilolite and growth of fibrous mordenite at $180^{\circ} \mathrm{C}$ (Blacic et al. 1982).

Zonation within the sorptive zeolite series in USW-G2 is part of a larger facies series that passes into analcime and then albite with increasing depth. These facies transitions are partly controlled by the local thermal gradient and have been documented in marine environments as zones: Zone $I$ is zeolite free, the transition to Zone II is marked by the first appearance of open-channel sorptive zeolites, Zone III is marked by the first appearance of analcime, and Zone IV is marked by the first appearance of authigenic albite (Iijima 1975). Zones II through IV overlap because of the natural reaction series that transform the marker minerals of one zone into the marker minerals of the next zone. Each reaction, with depth (increasing temperature), results in the production of less hydrous and less sorptive minerals from more hydrous and more sorptive minerals.

The present study of UE25b-1H adds a few wrirlkles to the facies concept. In UE25b-1H there is a $200-\mathrm{ft}(61-\mathrm{m})$ gap between the last occurrence of open-channel zeolites and the first occurrence of analcime at greater depth. If analcime is produced by the desilication and dehydration of open-channel zeolites, then this gap is difficult to explain. The answer to this difficulty can be found in the variable activity of alkaline cations in solution at the time of zeolite formation. High concentrations of specific cations can shift the stabilities of the less hydrous and less sorptive marker minerals to lower temperatures (e.g., a high $\mathrm{Na}^{+}$concentration can lead to the precipitat,ion of analcime or even albite rather than Na-rich open-channel zeolites in 
low-temperature saline lakes; Smyth and Caporuscio 1981). Thus an increase in ion concentration with depth might perfectly mimic the facies series of Iijima (Hoover 1968) even if there were no local geothermal gradient. Conversely, even if the geothermal gradient were appropriate for generating the four zones of Iijima's series, a locally pure water with low cation concentrations could lead to gaps in the facies sequence. Such conditions might explain the gap between zones of open-channel zeolites and analcime in drill hole UE25b-1H. The gap in this case may be an ancient zone of relatively pure water (perhaps a zone of greater lateral flow) within the Upper Tram Member. The conclusion to be drawn from the zeolite distributions in USW-G2 and UE25b-1H is that fluid compositions as well as thermal conditions control the formation and the stability of authigenic minerals. Because sorptive authigenic zeolites are important to the siting of a high-level waste repository, one must consider the long-term alterations in water composition as well as the temperature rise caused by the repository.

Samples from both USW-G2 and UE25b-1H suggest that zeolites of the clinoptilolite-heulandite series and zeolites of the mordenite series may vary substantially in their preferred modes of occurrence when both can be found within a single hand-sample. Samples greatly zeolitized by both series tend to have abundant coarse euhedral clinoptilolite-heulandite in void spaces or in relict shards, while mordenite remains fine-grained and is confined to the obscure groundmass regions between open spaces and once-glassy relicts. These relations suggest that mordenite may form more readily within a dense aggregate, whereas clinoptilolite-heulandite may form easily in open areas. However, it is important to note that mordenite may form in open spaces at the expense of clinoptilolite during experiments on natural samples (Blacic 1982). Could this happen under the heat load from a repository? Or would both sorptive zeolite series be destabilized? Clearly more work is needed, and studies in progress at Los $A l a m o s$ are addressing these and other questions regarding zeolite stability.

If zeolite stability can be assured within the limits of repository design, then what is the most favorable geometry for zeolite barriers surrounding the repository? Clearly the answer to this question depends on the pathways of waste element migration. If these pathways are dominantly downward, or downward with only a secondary lateral component, then it will be an obvious advantage to have the greatest possible thickness of zeolitized 
horizons underlying the repository. This may be one of the best advantages for developing a repository in the Topopah Spring Member of the Paintbrush Tuff. This advantage will be weakened should significant lateral transport occur, and the advantage will be totally lost if upward transport can be demonstrated. Conversely, a repository sited below the zeolitized horizons (e.g., within the Lithic Ridge Tuff) would not use these natural barriers to advantage unless transport were dominantly lateral (eastward to Fortymile Wash) or upward. If zeolitized horizons are to be used effectively for repository siting, then the detailed hydrology of both saturated and unsaturated zones must be known, as well as the expected alterations in these systems due to repository development.

B. Clay Mineralogy as a Guide to High-Temperature Alteration History

Clay minerals in USW-G2 and UE25b-1H are fairly ubiquitous, similar to their distribution in USW-GI (Carroll et al. 1981; Bish 1981), although parts of the Calico Hills unit are smectite-poor. Although some smectites occur as a late-stage fracture filling, most are concentrated in pumice relicts or scattered within the groundmass of these samples. The smectites in the upper portions of USW-G2 are predominantly sodium- and calcium-saturated montmorillonite-beidellites with few or no interstratified illite layers. The change from pure smectite to interstratified illite/smectite with depth is reflected both in the $x$-ray diffraction patterns and in the chemical composition of the clays (Tables A-IV and A-V). In general, the amounts of potassium and the amount of interstratified illite increase with depth, but the smectites remain expandable until about $5000-\mathrm{ft}$ (1524-m) depth in USW-G2. Below that depth, nonexpandable illite and chlorite are present. In USW-G2, the transition from a one water-layer smectite to a collapsed (but still expandable) smectite takes place about $1500 \mathrm{ft}(457 \mathrm{~m})$, but there are scattered occurrences of collapsed smectites above that depth and several expanded smectites below $1500 \mathrm{ft}$. At depths shallower than $3500 \mathrm{ft}(1067 \mathrm{~m})$, randomly interstratified smectite/illites occur, analogous to what was observed in USW-GI (Bish 1981), with a sporadic increase in the degree of interstratification with illite with depth. Below $3500 \mathrm{ft}$, there is an abrupt increase in the amount of interstratified illite, with ordered interstratifications appearing. Below $3800 \mathrm{ft}(1158 \mathrm{~m})$, a long-range ordered illite-rich interstratification occurs. The material is referred to as Kalkberg ordered and occurs with illite contents between 80 and $95 \%$. 
The randomly interstratified smectite/illites occurring shallower than $3500 \mathrm{ft}(1067 \mathrm{~m})$ are consistent with temperatures of less than $40^{\circ} \mathrm{C}$. However, the ordered illite/smectites occurring below $3500 \mathrm{ft}$ suggest temperatures above $100^{\circ} \mathrm{C}$ (Perry and Hower 1970), and the Kalkberg ordered clays occurring below $3800 \mathrm{ft}(1158 \mathrm{~m})$ are consistent with temperatures ranging from 180 to $230^{\circ} \mathrm{C}$. Such an abrupt, and, in places, sporadic increase in temperature cannot be explained simply through the imposition of a high paleogeotherm. These data, together with the occurrence of sulfides, barite, and fluorite in the lower parts of the drill holes, suggest that considerable hydrothermal alteration has taken place. There is some evidence for the presence of two generations of smectites throughout the cores, and expandable smectites coexist with collapsed smectites in scattered samples down to about $5000 \mathrm{ft}$ $(1524 \mathrm{~m})$ in USW-G2. For example, the presence of a smectite with little or no interstratified illite at $4949 \mathrm{ft}(1508 \mathrm{~m})$ in USW-G2 demonstrates that low-temperature alteration has taken place after the higher temperature hydrothermal alteration. This type of occurrence is evidence that hydrothermal alteration has not been pervasive for some time. Although hydrothermal alteration may be considered to be an unlikely future event, it may be advisable to date the mineralized veins of USW-G2 or UE25b-1H to determine exactly how old this past hydrothermal system was when it stopped operating. C. Geologic Units Most Favorable for Further Study as Possible Waste Repository Horizons

At present, we wish to emphasize three units that provide possible sites for a nuclear waste repository at Yucca Mountain. These units are the Topopah Spring member of the Paintbrush Tuff, the Tuff of Calico Hills and the Lithic Ridge Tuff. These three units provide the option of siting in either the unsaturated (Topopah Springs and Calico Hills, in part) or deep, saturated zones (Lithic Ridge). Two units are effectively bounded on one side only by truly sorptive minerals (Topopah Springs and Lithic Ridge). Therefore, if sited in either of these two units, the issues of hydrologic flow and bounding zeolite horizon geometry take on critical importance.

Other major considerations are as follows. (1) In the Lithic Ridge Tuff the ambient geothermal gradient augmented by the burial of heat-producing waste will lead to high underground working temperatures. This problem must be dealt with to assure worker safety.

(2) Open fractures in the Topopah 
Spring may be due to recent tectonic activity and must be understood before the Topopah Spring could be accepted as a repository site.

The Tuff of Calico Hills offers an alternative to the other two units. A. repository within a thick sequence of zeolitized tuffs offers a very effective barrier to radionuclide migration. As discussed earlier, these minerals must not be thermally stressed to produce unfavorable phase transformations. The zeolite phase stabilities and the possible effects of zeolite water loss are still poorly understood. Burial within zeolitized units can be made very effective by either reducing the thermal loading of the repository or by cooling the waste before emplacement in a heavily zeolitized unit.

\section{ACKNOWLEDGMENTS}

Preliminary arill core lithology logs and the core samples for this project were supplied by the United States Geological Survey. We greatly appreciate the advice, insights, and encouragement from F. Maldonado, R. Spengler, and $W$. Carr of that organization.

Thin sections of outstanding quality were prepared by Dave Mann and Tino Lucero. Roland Hagan and Lois Gritzo assisted with microprobe and other laboratory work. Barbara Hahn typed the manuscript and illustrations were prepared by Carol Anderson. Helpful editorial and technical reviews were provided by Aaron Waters, Bruce Crowe, and Glenda Cremer.

\section{REFERENCES}

Bence, A. E. and A. L. Albee, "Empirical Correction Factors for Electron Microanalysis of Silicates and 0xides," J. Geol., 76, 382-403 (1968).

Bish, D. L., "Detailed Mineralogical Characterization of the Bullfrog and Tram Members in USW-G1, with Emphasis on Clay Mineralogy," Los Alamos National Laboratory report LA-9021-MS (October 1981).

Bish, D. L., F. A. Caporuscio, J. F. Copp, B. M. Crowe, J. D. Purson, J. R. Smyth, and R. G. Warren, "Preliminary Stratigraphic and Petrologic Characicerization of Core Samples from USW-G1, Yucca Mountain, Nevada," Los Alamos National Laboratory report LA-8840-MS (1981).

Blacic, J., J. Carter, P. Halleck, P. Johnson, T. Shankland, R. Andersen, K. Spicochi, and A. Heller, "Effects of Long-Term Exposure of Tuffs to High-Leve Nuclear Waste Repository Conditions," Los Alamos National Laboratory report (in preparation). 
Blankennagel, R. K. and J. E. Weir, "Geohydrology of the Eastern Part of Pahute Mesa, Nevada Test Site, Nye County, Nevada," U.S.Geol. Surv. Prof. Paper 712-B (1973).

Byers, F. M. Jr., W. J. Carr, P. P. Orkild, W. D. Quinlivan, and K. A. Sargent, "Volcanic Suites and Related Cauldrons of Timber Mountain-0asis Valley Caldera Complex, Southern Nevada," U.S. Geol. Surv. Prof. Paper 919 , p. 70 (1976).

Carroll, P. I., F. A. Caporuscio, and D. L. Bish, "Further Description of the Topopah Spring Member of the Paintbrush Tuff in Drill Holes UE25a-1 and USW-G1 and of the Lithic Rich Tuff in USW-G1, Yucca Mountain, Nevada," Los Alamos National Laboratory report LA-9000-MS (November 1981).

Christiansen, R. L. and P. W. Lipman, "Geologic Map of the Topopah Spring NW Quadrangle, Nye County, Nevada," U.S. Geol. Surv. Quad. Map GQ-444 (1965).

Christiansen, R. L., P. W. Lipman, W. J. Carr, F. M. Byers, Jr., P. P. Orkild, and K. A. Sargent, "Timber Mountain-0asis Valley Caldera Complex of Southern Nevada," Geol. Soc. Am. Bul1., v. 88, 943-959 (1977).

Haggerty, S. E., "Oxidation of Opaque Mineral 0xides in Basalts," in 0xide Minerals, Min. Soc. Am. Short Course Notes 3, H6-1 - H6-100 (1976).

Heiken, G. H. and M. L. Bevier, "Petrology of Tuff Units from the J-13 Drill Site, Jackass Flats, Nevada," Los Alamos National Laboratory report LA-7563-MS, p. 55 (February 1979).

Hoover, D. L., "Genesis of Zeolites, Nevada Test Site," in Nevada Test Site, Ge01. Soc. Am. Mem. 110, 275-284 (1968).

Iijima, A., "Effect of Pore Water to Clinoptilolite-Analcime-Albite Reaction Series," Jour. Fac. Sci. Univ. Tokyo, Sec. II, v. 19, 133-148 (1975).

Kistler, R. W., "Potassium Argon Ages of Volcanic Rocks in Nye and Esmeralda Counties, Nevada," in Nevada Test Site, Geol. Soc. Am. Mem. 110, 251-262 (1968).

Lipman, P. W., R. L. Christiansen, and J. T. O'Connor, "A Compositionally Zoned Ash-Flow Sheet in Southern Nevada," U.S. Geol. Surv. Prof. paper 524-F, F-1 - F-47 (1966).

Maldonado, F. and S. L. Koether, "Stratigraphy, Preliminary Petrology and Some Structural Features of Tertiary Volcanic Rocks at a Deep Drill Hole, Yucca Mountain, Nye County, Nevada," U.S. Geol. Surv. Open File Report (in preparation).

Perry, E. A. Jr. and J. Hower, "Burial Diagenesis in Gulf Coast Pelitic Sediments," Clays and Clay Min., v. 18, 165-177 (1970).

Smyth, J. R. and F. A. Caporuscio, "Review of the Thermal Stability and Cation Exchange Properties of the Zeolite Minerals Clinoptilolite, Mordenite, and Analcime: Applications to Radioactive Waste Isolation in Silicic Tuff," Los Alamos National Laboratory report LA-8841-MS (June 1981). 
Spengler, R. W., "Preliminary Lithologic Log of Drill Hole UE25b-1H" (Letter, 1981).

Spengler, R. W., D. C. Muller, and R. B. Livermore, "Preliminary Report on the Geology and Geophysics of Drill Hole UE25a-1, Yucca Mountain, Nevada Test Site," U.S. Geol. Surv. Open-File Report 79-1244, p. 43 (1979).

Sykes, M. L., G. H. Heiken, and J. R. Smyth, "Mineralogy and Petrology of Tuff Units from the UE25a-1 Drill Site, Yucca Mountain, Nevada," Los alamos Scientific Laboratory repcit LA-8139-MS (November 1979). 
APPENDIX A

GLASS, ZEOLITE, AND CLAY ANALYSES FROM DRILL HOLES USW-G2 AND UE25b-1H

TABLE A-I

GLASS ANALYSES FROM THE UPPER PAINTBRUSH TUFF, DRILL HOLE USW-G2

Yucca Mountain

Shards

$\begin{array}{lrrrrrrrrrr}\mathrm{SiO}_{2} & 73.68 & 72.46 & 73.25 & 72.95 & 72.43 & 72.22 & 73.30 & 73.04 & 73.07 & 72.00 \\ \mathrm{Al}_{2} \mathrm{O}_{3} & 12.07 & 12.30 & 12.11 & 11.76 & 12.16 & 12.07 & 12.07 & 11.93 & 11.31 & 12.20 \\ \mathrm{TiO}_{2} & 0.14 & 0.18 & 0.16 & 0.15 & 0.16 & 0.13 & 0.10 & 0.13 & 0.10 & 0.16 \\ \mathrm{FeO} & 0.91 & 0.88 & 0.76 & 0.89 & 0.88 & 0.69 & 0.81 & 0.84 & 0.65 & 0.91 \\ \mathrm{CaO} & 0.28 & 0.26 & 0.21 & 0.25 & 0.26 & 0.26 & 0.27 & 0.24 & 0.23 & 0.25 \\ \mathrm{Na}_{2} \mathrm{O} & 4.26 & 4.56 & 4.19 & 4.45 & 4.62 & 4.68 & 4.55 & 4.59 & 4.52 & 4.43 \\ \mathrm{~K}_{2} \mathrm{O} & 4.64 & 4.43 & 4.07 & 4.53 & 4.34 & 4.35 & 4.37 & 4.00 & 3.92 & 4.23 \\ \Sigma & 95.98 & 95.07 & 94.74 & 94.97 & 94.86 & 94.40 & 95.46 & 94.76 & 93.79 & 94.17\end{array}$

G2-358 Bedded Unit

\begin{tabular}{|c|c|c|c|c|c|}
\hline \multirow[b]{2}{*}{$\mathrm{SiO}_{2}$} & \multirow{2}{*}{ Shard } & \multicolumn{4}{|c|}{ Pumices } \\
\hline & & 72.46 & 74.05 & 73.24 & 73.39 \\
\hline $\mathrm{Al}_{2} \mathrm{O}_{3}$ & 11.67 & 11.61 & 11.84 & 11.88 & 11.86 \\
\hline $\mathrm{TiO}_{2}$ & 0.16 & 0.13 & 0.10 & 0.13 & 0.107 \\
\hline $\mathrm{Fe} 0$ & 0.83 & 0.77 & 0.62 & 0.66 & 0.81 \\
\hline $\mathrm{CaO}$ & 0.19 & 0.18 & 0.21 & 0.24 & 0.22 \\
\hline $\mathrm{Na}_{2} \mathrm{O}$ & 3.99 & 4.33 & 4.40 & 4.54 & 4.38 \\
\hline $\mathrm{K}_{2} \mathrm{O}$ & 4.22 & 4.22 & 3.99 & 3.95 & 4.06 \\
\hline Total & 93.07 & 93.70 & 95.22 & 94.64 & 94.79 \\
\hline
\end{tabular}

G2-547 Pah Canyor:

\begin{tabular}{|c|c|c|c|c|c|c|c|c|}
\hline \multirow[b]{2}{*}{$\mathrm{SiO}_{2}$} & \multicolumn{5}{|c|}{ Vitrophyric Clast } & \multicolumn{3}{|c|}{ Shards } \\
\hline & 71.05 & 72.98 & 72.19 & 73.55 & 73.64 & 70.41 & 70.96 & 70.96 \\
\hline $\mathrm{Al}_{2} \mathrm{O}_{3}$ & 11.77 & 11.95 & 12.16 & 12.23 & 12.01 & 12.87 & 12.91 & 13.19 \\
\hline $\mathrm{TiO}_{2}$ & 0.13 & 0.09 & 0.09 & 0.15 & 0.09 & 0.21 & $0.1 \epsilon$ & 0.20 \\
\hline $\mathrm{FeO}$ & 0.85 & 0.73 & 0.76 & 0.75 & 0.70 & 0.99 & 0.67 & 1.02 \\
\hline $\mathrm{CaO}$ & 0.56 & 0.54 & 0.51 & 0.45 & 0.48 & 0.34 & 0.34 & 0.38 \\
\hline $\mathrm{Na}_{2} \mathrm{O}$ & 3.24 & 3.36 & 3.67 & 3.53 & 3.50 & 3.69 & 3.70 & 3.89 \\
\hline $\mathrm{K}_{2}{ }^{0}$ & 4.71 & 4.84 & 5.07 & 4.71 & 4.37 & 5.17 & 4.79 & 4.95 \\
\hline Total & 92.31 & 94.59 & 94.44 & 95.38 & 95.29 & 93.68 & 93.52 & 94.58 \\
\hline
\end{tabular}


TABLE A-II

\section{ZEOLITE ANALYSES FROM DRILL HOLE USW-G2 ${ }^{\alpha}$}

Pah Canyon Member of the Paintbrush Tuff (cont.)

(561-ft, 171-m depth)

Mg-Heulandite in Pumice Vesicle

SiO

$\mathrm{TiO}_{2}$

$\mathrm{Al}_{2} \mathrm{O}_{3}$

$\mathrm{Fe} 0$

$8 \mathrm{a} 0$

$\mathrm{MgO}$

$\mathrm{CaO}$

$\mathrm{Na}_{2} \mathrm{O}$

$\mathrm{K}_{2} \mathrm{O}$

$\Sigma$

Si

$\mathrm{Ti}$

Al

$\Sigma_{\text {tet }}$

$\mathrm{Fe}$

$\mathrm{Ba}$

$\mathrm{Mg}$

$\mathrm{Ca}$

$\mathrm{Na}$

$\mathrm{K}$

$\Sigma_{\text {large cations }}$

$\Sigma_{\text {cations }}$ $\begin{array}{lll}67.50 & 67.73 \quad 65.59\end{array}$

0.00

0.00

0.00

67.64

0.00

12.43

13.04

12.82

12.86

$12.45 \quad 12.60$

0.00

0.00

0.00

0.00

0.00

0.00

0.00

0.00

0.00

0.00

0.00

0.00

1.05

1.17

0.98

0.93

1.03

0.99

3.97

4.29

4.18

4.41

3.86

4.23

0.22

0.21

0.28

0.26

0.23

1.18

0.19

1.31

0.98

1.37

1.06

86.40

1.27

87.66

87.20

8.7 .35

85.11

86.06

$$
14.86
$$

14.71

14.76

14.67

14.85

14.76

0.00

0.00

0.00

0.00

0.00

3.22

0.00

3.1

3.34

3.2

3.38

18.07

3.28

18.03

18.05

18.05

18.14

0.00

18.04

0.00

0.00

0.00

0.00

0.00

0.00

0.00

0.00

0.00

0.00

0.00

0.31

0.33

0.00

0.92

0.99

1.05

0.09

0.0

0.97

0.11

0.90

0.09

0.36

0.27

0.37

0.30

0.33

1.65

1.7

1.72

1.76

1.77

$1.65 \quad 1.76$

$19.74 \quad 19.7$

$19.72 \quad 19.80$

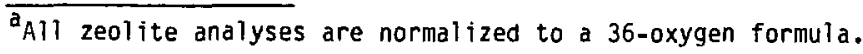


TABLE A-II (cont.)

Pan Canyon Member of the Paintbrush Tuff (cont.)

(584-ft, $178-m$ depth)

Mg-Heulandite in Small Fracture

$\begin{array}{lrrrrrrr}\mathrm{SiO}_{2} & 62.60 & 65.55 & 66.98 & 62.06 & 61.14 & 61.61 & 62.88 \\ \mathrm{TiO}_{2} & 0.03 & 0.00 & 0.00 & 0.00 & 0.00 & 0.00 & 0.00 \\ \mathrm{Al}_{2} \mathrm{O}_{3} & 13.33 & 13.78 & 13.59 & 13.59 & 13.47 & 14.04 & 14.04 \\ \mathrm{FeO} & 0.00 & 0.00 & 0.00 & 0.00 & 0.00 & 0.00 & 0.00 \\ \mathrm{Ba0} & 0.12 & 0.02 & 0.00 & 0.00 & 0.07 & 0.00 & 0.09 \\ \mathrm{MgO} & 1.41 & 1.47 & 1.35 & 1.53 & 1.55 & 1.75 & 1.86 \\ \mathrm{CaO} & 4.41 & 4.23 & 4.16 & 4.03 & 3.98 & 4.09 & 4.08 \\ \mathrm{Na}_{2}{ }^{0} & 0.02 & 0.18 & 0.03 & 0.13 & 0.14 & 0.12 & 0.10 \\ \mathrm{~K}_{2}{ }^{2} & 0.63 & 1.09 & 0.75 & 0.97 & 0.95 & 0.59 & 0.54 \\ \Sigma & 82.57 & 86.42 & 86.85 & 82.31 & 81.29 & 82.21 & 83.60 \\ & & & & & & & \\ \mathrm{Si} & 14.43 & 14.45 & 14.62 & 14.36 & 14.34 & 14.26 & 14.30 \\ \mathrm{Ti} & 0.00 & 0.00 & 0.00 & 0.00 & 0.00 & 0.00 & 0.00 \\ \mathrm{Al} & 3.62 & 3.58 & 3.49 & 3.70 & 3.72 & 3.83 & 3.75 \\ \Sigma_{\text {tet }} & 18.05 & 18.03 & 18.11 & 18.06 & 18.06 & 18.09 & 18.05 \\ \mathrm{Fe} & 0.00 & 0.00 & 0.00 & 0.00 & 0.00 & 0.00 & 0.00 \\ \mathrm{Ba} & 0.0 & 0.00 & 0.00 & 0.00 & 0.00 & 0.00 & 0.00 \\ \mathrm{Mg} & 0.48 & 0.51 & 0.44 & 0.52 & 0.54 & 0.59 & 0.63 \\ \mathrm{Ca} & 1.08 & 0.99 & 0.97 & 1.00 & 1.00 & 1.01 & 0.99 \\ \mathrm{Na} & 0.01 & 0.07 & 0.01 & 0.05 & 0.06 & 0.05 & 0.04 \\ \mathrm{~K} & 0.18 & 0.30 & 0.2 & 0.28 & 0.28 & 0.17 & 0.15 \\ \Sigma & 1.75 & 1.87 & 1.62 & 1.85 & 1.88 & 1.82 & 1.81 \\ { }_{2} \text { large cations } & 19.80 & 19.90 & 19.73 & 19.91 & 19.94 & 19.91 & 19.86\end{array}$

$\overline{a_{A 1} l \text { zeolite analyses }}$ are normalized to a 36 -oxygen formula. 


\section{TABLE A-II (cont.)}

Pah Canyon Member of the Paintbrush Tuff (cont.) (675-ft, 206-m depth)

\begin{tabular}{|c|c|c|c|c|c|c|}
\hline \multirow[b]{2}{*}{$\mathrm{SiO}_{2}$} & \multicolumn{6}{|c|}{ Mg-Heulandite in Open Vugs } \\
\hline & 67.49 & 60.02 & 60.07 & 67.20 & 65.43 & 67.21 \\
\hline $\mathrm{T}_{\mathrm{O}} \mathrm{O}_{2}$ & 0.00 & 0.00 & 0.00 & 0.00 & 0.08 & 0.00 \\
\hline $\mathrm{Al}_{2} \mathrm{O}_{3}$ & 13.28 & 11.51 & 12.11 & 13.38 & 13.27 & 13.05 \\
\hline $\mathrm{FeO}$ & 0.03 & 0.04 & 0.03 & 0.33 & 0.26 & 0.03 \\
\hline $8 \mathrm{a} 0$ & 0.51 & 0.32 & 0.24 & 0.42 & 0.22 & 0.40 \\
\hline MgO & 0.98 & 0.80 & 0.88 & 0.95 & 0.97 & 0.90 \\
\hline $\mathrm{CaO}$ & 4.11 & 3.74 & 3.65 & 4.07 & 3.95 & 3.90 \\
\hline $\mathrm{Na}_{2} \mathrm{O}$ & 0.11 & 0.10 & 0.28 & 0.25 & 0.14 & 0.36 \\
\hline $\mathrm{K}_{2} \mathrm{O}$ & 1.28 & 1.31 & 1.00 & 1.62 & 1.68 & 1.86 \\
\hline$\Sigma$ & 87.80 & 77.84 & 78.26 & 88.22 & 86.00 & 87.71 \\
\hline Si & 14.68 & 14.73 & 14.63 & 14.61 & 14.58 & 14.69 \\
\hline$T i$ & 0.00 & 0.00 & 0.00 & 0.00 & 0.01 & 0.00 \\
\hline Al & 3.40 & 3.33 & 3.47 & 3.42 & 3.47 & 3.36 \\
\hline$\Sigma_{\text {tet }}$ & $18 ?$ & 18.06 & 18.10 & 18.03 & 18.06 & 18.05 \\
\hline $\mathrm{Fe}$ & 0.00 & 0.00 & 0.00 & 0.06 & 0.05 & 0.00 \\
\hline Ba & 0.04 & 0.03 & 0.02 & 0.03 & 0.01 & 0.03 \\
\hline $\mathrm{Mg}$ & 0.32 & 0.29 & 0.32 & 0.31 & 0.32 & 0.29 \\
\hline $\mathrm{Ca}$ & 0.95 & 0.98 & 0.95 & 0.94 & 0.94 & 0.91 \\
\hline $\mathrm{Na}$ & 0.05 & 0.04 & 0.13 & 0.10 & 0.06 & 0.15 \\
\hline k & 0.35 & 0.40 & 0.31 & 0.45 & 0.48 & 0.52 \\
\hline${ }^{\Sigma}$ large cations & 1.71 & 1.74 & 1.73 & 1.89 & 1.86 & 1.90 \\
\hline$\Sigma_{\text {cations }}$ & 19.79 & 19.80 & 19.83 & 19.92 & 19.92 & 19.95 \\
\hline $\mathrm{Si} / \mathrm{Si}+\mathrm{Al}$ & 0.81 & 0.82 & 0.81 & 0.81 & 0.81 & 0.81 \\
\hline
\end{tabular}




\section{TABLE A-II (cont.)}

Topopah Spring Member of the Paintbrush Tuff

\begin{tabular}{|c|c|c|c|}
\hline & $\begin{array}{c}(762-\mathrm{ft}, 232-\mathrm{m} \text { depth) } \\
\text { Mg-cl inoptilolite } \\
\text { in pumice }\end{array}$ & $\begin{array}{l}\text { (1691-ft, } 515-n \\
\text { Massive } \\
\text { clinoptilolite }\end{array}$ & $\begin{array}{l}\text { depth) } \\
\text { Clinoptilolite }\end{array}$ \\
\hline $\mathrm{SiO}_{2}$ & 68.42 & 67.86 & 66.32 \\
\hline $\mathrm{TiO}_{2}$ & 0.05 & 0.00 & 0.00 \\
\hline $\mathrm{Al}_{2} \mathrm{O}_{3}$ & 11.73 & 12.43 & 12.31 \\
\hline $\mathrm{Fe} 0$ & 0.24 & 0.02 & 0.01 \\
\hline $\mathrm{BaO}$ & 0.00 & 0.00 & 0.07 \\
\hline MgO & 0.78 & 0.04 & 0.00 \\
\hline $\mathrm{CaO}$ & 2.94 & 2.97 & 3.14 \\
\hline $\mathrm{Na}_{2} \mathrm{O}$ & 0.23 & 0.96 & 0.84 \\
\hline $\mathrm{K}_{2} \mathrm{O}$ & 2.39 & 3.79 & 3.55 \\
\hline$\varepsilon$ & 86.78 & 88.07 & 87.74 \\
\hline Si & 15.01 & 14.87 & 14.90 \\
\hline$T i$ & 0.00 & 0.00 & 0.00 \\
\hline A1 & 3.03 & 3.21 & 3.19 \\
\hline$\Sigma_{\text {tet }}$ & 18.04 & 18.08 & 18.09 \\
\hline $\mathrm{Fe}$ & 0.04 & 0.00 & 0.00 \\
\hline $\mathrm{Ba}$ & 0.00 & 0.00 & 0.00 \\
\hline $\mathrm{Mg}$ & 0.06 & 0.01 & 0.00 \\
\hline $\mathrm{Ca}$ & 0.69 & 0.69 & 0.73 \\
\hline Na & 0.10 & 0.40 & 0.36 \\
\hline$k$ & 0.15 & 1.05 & 0.99 \\
\hline Elarge cations & 1.03 & 2.16 & 2.08 \\
\hline${ }^{\text {Ecations }}$ & 19.07 & 20.23 & 20.17 \\
\hline
\end{tabular}


TABLE A-II (cont.)

Topopah Spring Member of the Paintbrush Tuff

(1745-ft, 532-m depth)

Coarse Clinoptilolite in Vugs

$\begin{array}{lrrrrrrr}\mathrm{SiO}_{2} & 64.59 & 64.92 & 66.71 & 65.84 & 65.00 & 65.46 & 64.61 \\ \mathrm{TiO}_{2} & 0.00 & 0.00 & 0.00 & 0.00 & 0.04 & 0.00 & 0.00 \\ \mathrm{Al}_{2} \mathrm{O}_{3} & 12.61 & 12.55 & 12.04 & 12.75 & 12.61 & 12.43 & 12.51 \\ \mathrm{FeO} & 0.04 & 0.01 & 0.00 & 0.08 & 0.01 & 0.00 & 0.01 \\ \mathrm{BaO} & 0.16 & 0.16 & 0.14 & 0.00 & 0.03 & 0.00 & 0.00 \\ \mathrm{MgO} & 0.00 & 0.00 & 0.00 & 0.00 & 0.00 & 0.00 & 0.00 \\ \mathrm{CaO} & 3.57 & 3.41 & 3.52 & 2.96 & 3.20 & 3.48 & 3.49 \\ \mathrm{Na}_{2} \mathrm{O}^{2} & 1.02 & 1.32 & 0.96 & 0.97 & 1.32 & 1.23 & 1.13 \\ \mathrm{~K}_{2} \mathrm{O} & 2.78 & 3.26 & 3.77 & 3.43 & 3.45 & 3.01 & 3.20 \\ \Sigma & 84.77 & 85.64 & 87.14 & 86.03 & 85.66 & 85.61 & 84.95 \\ & & & & & & & \\ \mathrm{Si} & 14.70 & 14.69 & 14.83 & 14.76 & 14.68 & 14.75 & 14.70 \\ \mathrm{Ii} & 0.00 & 0.00 & 0.00 & 0.00 & 0.01 & 0.00 & 0.00 \\ \mathrm{Al} & 3.38 & 3.35 & 3.15 & 3.37 & 3.35 & 3.30 & 3.35 \\ \Sigma_{\text {tet }} & 18.08 & 18.04 & 17.98 & 18.13 & 18.04 & 18.05 & 18.05 \\ \mathrm{Fe} & 0.01 & 0.00 & 0.00 & 0.02 & 0.00 & 0.00 & 0.00 \\ \mathrm{Ba} & 0.01 & 0.01 & 0.01 & 0.00 & 0.00 & 0.00 & 0.00 \\ \mathrm{Mg} & 0.00 & 0.00 & 0.00 & 0.00 & 0.00 & 0.00 & 0.00 \\ \mathrm{Ca} & 0.87 & 0.82 & 0.84 & 0.71 & 0.77 & 0.83 & 0.85 \\ \mathrm{Na} & 0.45 & 0.57 & 0.41 & 0.42 & 0.58 & 0.54 & 0.49 \\ \mathrm{~K} & 0.80 & 0.94 & 1.06 & 0.97 & 0.99 & 0.86 & 0.93 \\ \Sigma & 2.12 & 2.33 & 2.31 & 2.10 & 2.34 & 2.23 & 2.27 \\ \Sigma & 20.21 & 20.38 & 20.29 & 20.25 & 20.38 & 20.27 & 20.32 \\ \Sigma & & & & & & & \end{array}$


TABLE A-II (cont.)

Tuffaceous Beds of Calico Hills

(2078-ft, 633-m depth)

Mg-Clinoptilolite in Vug

$\begin{array}{lrrr}\mathrm{SiO}_{2} & 70.01 & 66.08 & 69.57 \\ \mathrm{TiO}_{2} & 0.00 & 0.00 & 0.00 \\ \mathrm{Al}_{2} \mathrm{O}_{3} & 11.43 & 11.83 & 11.72 \\ \mathrm{FeO} & 0.00 & 0.00 & 0.00 \\ \mathrm{BaO} & 0.00 & 0.00 & 0.00 \\ \mathrm{MgO} & 0.45 & 0.46 & 0.44 \\ \mathrm{CaO} & 2.88 & 2.81 & 2.81 \\ \mathrm{Na}_{2} \mathrm{O} & 0.66 & 0.65 & 0.64 \\ \mathrm{~K}_{2} \mathrm{O} & 2.62 & 2.72 & 2.37 \\ \Sigma & 88.05 & 84.57 & 87.55\end{array}$

Si

Ti

$\begin{array}{lll}15.16 & 14.94 \quad 15.12\end{array}$

$\begin{array}{lll}0.00 & 0.00 & 0.00\end{array}$

A] $\quad 2.91 \quad 3.15 \quad 3.00$

$\begin{array}{llll}\Sigma_{\text {tet }} & 18.07 & 18.09 & 18.12\end{array}$

$\mathrm{Fe}$

$\begin{array}{lll}0.00 & 0.00 & 0.00\end{array}$

$\begin{array}{llll}\mathrm{Ba} & 0.00 & 0.00 & 0.00\end{array}$

$\begin{array}{llll}\mathrm{Mg} & 0.14 & 0.15 & 0.14\end{array}$

$\begin{array}{llll}\text { Ca } & 0.67 & 0.68 & 0.65\end{array}$

$\begin{array}{llll}\mathrm{Na} & 0.27 & 0.29 & 0.27\end{array}$

$\begin{array}{llll}\text { K } & 0.72 & 0.78 & 0.66\end{array}$

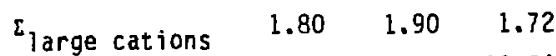

${ }^{\Sigma}$ cations

$\begin{array}{lll}19.87 & 19.99 & 19.84\end{array}$ 


\section{TABLE A-II (cont.)}

Tuffaceous Beds of Calico Hills (cont.)

(2158-ft, 658-m depth)

Large Mg-Clinoptilolite in Vug

$\begin{array}{lrrrrrr}\mathrm{SiO}_{2} & 66.58 & 67.55 & 68.32 & 68.02 & 65.57 & 66.61 \\ \mathrm{TiO}_{2} & 0.01 & 0.00 & 0.00 & 0.00 & 0.00 & 0.00 \\ \mathrm{Al}_{2} \mathrm{O}_{3} & 12.69 & 12.20 & 12.66 & 12.91 & 11.42 & 11.65 \\ \mathrm{Fe0} & 0.00 & 0.00 & 0.00 & 0.00 & 0.00 & 0.00 \\ \mathrm{Ba0} & 0.00 & 0.00 & 0.00 & 0.00 & 0.00 & 0.00 \\ \mathrm{MgO} & 0.56 & 0.48 & 0.52 & 0.54 & 0.41 & 0.51 \\ \mathrm{CaO} & 3.13 & 3.43 & 3.36 & 3.50 & 3.23 & 3.23 \\ \mathrm{Na}_{2} \mathrm{O}^{2} & 0.97 & 0.79 & 0.94 & 0.5 \mathrm{~B} & 0.42 & 0.77 \\ \mathrm{~K}_{2} \mathrm{O}^{2} & 2.91 & 2.51 & 2.84 & 2.45 & 2.23 & 2.64 \\ \Sigma & 86.86 & 84.92 & 88.64 & 88.00 & 83.28 & 85.42 \\ & & & & & & \\ \mathrm{Si} & 14.74 & 14.79 & 14.81 & 14.79 & 15.01 & 14.94 \\ \mathrm{Ti} & 0.05 & 0.00 & 0.00 & 0.00 & 0.00 & 0.00 \\ \mathrm{Al} & 3.30 & 3.24 & 3.23 & 3.30 & 3.08 & 3.08 \\ \Sigma_{\text {tet }} & 18.09 & 18.03 & 18.04 & 18.09 & 18.09 & 18.02 \\ \mathrm{Fe} & 0.00 & 0.00 & 0.00 & 0.00 & 0.00 & 0.00 \\ \mathrm{Ba} & 0.00 & 0.00 & 0.00 & 0.00 & 0.00 & 0.00 \\ \mathrm{Mg} & 0.18 & 0.16 & 0.17 & 0.17 & 0.14 & 0.16 \\ \mathrm{Ca} & 0.74 & 0.83 & 0.77 & 0.81 & 0.78 & 0.77 \\ \mathrm{Na} & 0.41 & 0.34 & 0.39 & 0.24 & 0.18 & 0.33 \\ \mathrm{~K} & 0.82 & 0.72 & 0.78 & 0.68 & 0.64 & 0.75 \\ \Sigma_{1} & 2.15 & 2.05 & 2.11 & 1.90 & 1.74 & 2.01 \\ \Sigma_{\text {cations }} & 20.24 & 20.07 & 20.15 & 19.59 & 19.83 & 20.03 \\ & & & & & & \end{array}$




\section{TABLE A-II (cont.)}

Tuffaceous beds of Calico Hills (cont.)

(2325-ft, 709-m depth)

\begin{tabular}{lrrrrr} 
& \multicolumn{5}{c}{ Large Mg-Clinoptilolite in Vug } \\
\cline { 2 - 6 } $\mathrm{SiO}_{2}$ & 69.41 & 69.07 & 68.07 & 70.08 & 70.04 \\
$\mathrm{IiO}_{2}$ & 0.00 & 0.00 & 0.00 & 0.00 & 0.00 \\
$\mathrm{Al}_{2} \mathrm{O}_{3}$ & 12.00 & 11.91 & 11.75 & 12.66 & 12.56 \\
$\mathrm{FeO}$ & 0.03 & 0.00 & 0.00 & 0.03 & 0.03 \\
$\mathrm{Ba0}$ & 0.00 & 0.00 & 0.00 & 0.00 & 0.00 \\
$\mathrm{MgO}$ & 0.30 & 0.34 & 0.22 & 0.28 & 0.36 \\
$\mathrm{Ca0}$ & 3.45 & 3.25 & 3.44 & 3.53 & 3.47 \\
$\mathrm{Na}_{2}{ }^{0}$ & 1.07 & 0.58 & 0.57 & 0.95 & 0.71 \\
$\mathrm{~K}_{2}{ }^{0}$ & 2.36 & 2.16 & 1.60 & 2.45 & 2.15 \\
$\Sigma$ & 88.67 & 87.30 & 85.64 & 90.01 & 89.32 \\
& & & & & \\
$\mathrm{Si}$ & 14.98 & 15.06 & 15.08 & 14.91 & 14.95 \\
$\mathrm{Ti}$ & 0.00 & 0.00 & 0.00 & 0.00 & 0.00 \\
$\mathrm{Al}$ & 3.05 & 3.06 & 3.06 & 3.17 & 3.16 \\
$\Sigma_{\text {tet }}$ & 18.03 & 18.12 & 18.14 & 18.08 & 18.11 \\
$\mathrm{Fe}$ & 0.00 & 0.00 & 0.00 & 0.00 & 0.00 \\
$\mathrm{Ba}$ & 0.00 & 0.00 & 0.00 & 0.00 & 0.00 \\
$\mathrm{Mg}$ & 0.09 & 0.11 & 0.07 & 0.09 & 0.11 \\
$\mathrm{Ca}$ & 0.79 & 0.75 & 0.81 & 0.80 & 0.79 \\
$\mathrm{Na}$ & 0.44 & 0.24 & 0.24 & 0.39 & 0.29 \\
$\mathrm{~K}$ & 0.64 & 0.59 & 0.45 & 0.66 & 0.58 \\
$\Sigma_{1}$ arge cations & 1.96 & 1.69 & 1.57 & 1.94 & 1.77 \\
$\Sigma_{\text {cations }}$ & 19.99 & 19.81 & 19.71 & 20.02 & 19.88
\end{tabular}


TABLE A-I I (cont.)

Tuffaceous Beds of Calico Hills (cont.)

(2430-ft, 741-m depth)

Mg-Clinoptilolite in Vug

\begin{tabular}{|c|c|c|c|c|c|}
\hline $\mathrm{SiO}_{2}$ & 59.35 & 70.16 & 65.28 & 67.65 & 71.26 \\
\hline $\mathrm{TiO}_{2}$ & 0.00 & 0.00 & 0.00 & 0.00 & 0.00 \\
\hline $\mathrm{Al}_{2} \mathrm{O}_{3}$ & 10.67 & 11.64 & 10.45 & 12.07 & 12.04 \\
\hline $\mathrm{FeO}$ & 0.01 & 0.01 & 0.04 & 0.05 & 0.00 \\
\hline $\mathrm{BaO}$ & 0.15 & 0.15 & 0.12 & 0.40 & 0.00 \\
\hline $\mathrm{MgO}$ & 0.34 & 0.36 & 0.34 & 0.39 & 0.31 \\
\hline $\mathrm{CaO}$ & 2.82 & 2.77 & 2.48 & 3.15 & 3.08 \\
\hline $\mathrm{Na}_{2} \mathrm{O}$ & 0.43 & 0.64 & 0.32 & 0.61 & 0.72 \\
\hline $\mathrm{K}_{2} \mathrm{O}$ & 1.77 & 2.81 & 1.56 & 2.02 & 2.71 \\
\hline$\Sigma$ & 75.89 & 88.65 & 80.61 & 86.35 & 90.17 \\
\hline Si & 14.93 & 15.12 & 15.29 & 14.96 & 15.08 \\
\hline Ti & 0.00 & 0.00 & 0.00 & 0.00 & 0.00 \\
\hline A) & 3.16 & 2.95 & 2.88 & 3.14 & 3.00 \\
\hline$\Sigma_{\text {tet }}$ & 18.09 & 18.07 & 18.17 & 18.10 & 18.08 \\
\hline $\mathrm{Fe}$ & 0.00 & 0.00 & 0.00 & 0.00 & 0.00 \\
\hline $\mathrm{Ba}$ & 0.00 & 0.00 & 0.00 & 0.00 & 0.00 \\
\hline Mg & 0.13 & 0.11 & 0.12 & 0.13 & 0.09 \\
\hline $\mathrm{Ca}$ & 0.76 & 0.64 & 0.62 & 0.75 & 0.69 \\
\hline $\mathrm{Na}$ & 0.21 & 0.27 & 0.14 & 0.26 & 0.29 \\
\hline$k$ & 0.57 & 0.80 & 0.46 & 0.56 & 0.73 \\
\hline${ }^{\Sigma}$ large cations & 1.67 & 1.82 & 1.34 & 1.70 & 1.80 \\
\hline${ }^{\Sigma}$ cations & 19.76 & 19.89 & 19.41 & 19.80 & 19.88 \\
\hline $\mathrm{Si} / \mathrm{Si}+\mathrm{Al}$ & 0.83 & 0.84 & 0.84 & 0.83 & 0.83 \\
\hline
\end{tabular}


TABLE A-II (cont.)

Prow Pass member of the Crater Flat Tuff

(3067-ft, 935-m depth)

Clinoptilolite in Relict Glass Shard

$\begin{array}{lcccccc}\mathrm{SiO}_{2} & 74.1 & 74.7 & 74.5 & 73.4 & 74.3 & 69.7 \\ \mathrm{TiO}_{2} & 0.10 & 0.15 & 0.07 & 0.10 & 0.09 & 0.00 \\ \mathrm{Al}_{2} \mathrm{O}_{3} & 11.4 & 11.7 & 11.6 & 11.6 & 11.7 & 10.5 \\ \mathrm{Fe0} & 0.52 & 0.73 & 0.80 & 0.18 & 0.71 & 0.00 \\ \mathrm{BaO} & 0.11 & 0.16 & 0.08 & 0.11 & 0.18 & 0.18 \\ \mathrm{MgO} & 0.00 & 0.03 & 0.00 & 0.00 & 0.00 & 0.00 \\ \mathrm{CaO} & 0.34 & 0.32 & 0.29 & 0.29 & 0.34 & 2.70 \\ \mathrm{Na}_{2} \mathrm{O}^{2} & 4.60 & 4.66 & 4.48 & 4.74 & 4.77 & 2.48 \\ \mathrm{~K}_{2} \mathrm{O}^{2} & 3.04 & 3.06 & 2.86 & 3.17 & 2.87 & 0.51 \\ \Sigma & 94.2 & 95.4 & 94.6 & 93.6 & 94.9 & 86.1 \\ & & & & & & \\ \mathrm{Si} & 15.19 & 15.14 & 15.17 & 15.14 & 15.13 & 15.33 \\ \mathrm{Ti} & 0.01 & 0.00 & 0.01 & 0.01 & 0.01 & 0.00 \\ \mathrm{Al} & 2.74 & 2.78 & 2.78 & 2.81 & 2.80 & 2.72 \\ \Sigma_{\text {tet }} & 17.94 & 17.92 & 17.96 & 17.96 & 17.94 & 18.05 \\ \mathrm{Fe} & 0.08 & 0.12 & 0.13 & 0.03 & 0.12 & 0.00 \\ \mathrm{Ba} & 0.01 & 0.01 & 0.00 & 0.01 & 0.01 & 0.01 \\ \mathrm{Mg} & 0.00 & 0.00 & 0.00 & 0.00 & 0.00 & 0.00 \\ \mathrm{Ca} & 0.07 & 0.06 & 0.06 & 0.06 & 0.07 & 0.63 \\ \mathrm{Na} & 1.83 & 1.83 & 1.76 & 1.89 & 2.88 & 1.06 \\ \mathrm{~K} & 0.79 & 0.79 & 0.74 & 0.83 & 0.74 & 0.14 \\ \Sigma & 2.78 & 2.81 & 2.69 & 2.82 & 2.82 & 1.84 \\ \Sigma_{\text {large }} \text { cations } & 20.72 & 20.73 & 20.65 & 20.78 & 20.76 & 19.89\end{array}$


TABLE A-II (cont.)

Prow Pass Member of the Crater Flat Tuff (cont.)

3192-ft, 973-m depth)

Clinoptilolite in Relict Glass Shard

\begin{tabular}{|c|c|c|c|c|c|c|c|c|}
\hline $\mathrm{SiO}_{2}$ & 63.2 & 64.2 & 63.7 & 65.0 & 63.0 & 66.0 & 66.2 & 65.4 \\
\hline $\mathrm{TiO}_{2}$ & 0.00 & 0.03 & 0.03 & 0.00 & 0.05 & 0.04 & 0.00 & 0.00 \\
\hline $\mathrm{Al}_{2} \mathrm{O}_{3}$ & 12.2 & 12.5 & 12.2 & 12.5 & 12.8 & 12.6 & 12.8 & 12.2 \\
\hline $\mathrm{Fe} 0$ & 0.05 & 0.18 & 0.11 & 0.11 & 0.54 & 0.17 & 0.17 & 0.29 \\
\hline $\mathrm{BaO}$ & 0.00 & 0.00 & 0.00 & 0.00 & 0.17 & 0.00 & 0.05 & 0.00 \\
\hline $\mathrm{MgO}$ & 0.00 & 0.02 & 0.00 & 0.02 & 0.05 & 0.00 & 0.05 & 0.00 \\
\hline $\mathrm{CaO}$ & 2.06 & 2.25 & 2.05 & 1.91 & 2.16 & 2.09 & 2.43 & 1.72 \\
\hline $\mathrm{Na}_{2} \mathrm{O}$ & 3.20 & 3.26 & 3.61 & 3.61 & 3.33 & 3.26 & 3.08 & 3.32 \\
\hline $\mathrm{K}_{2} \mathrm{O}$ & 1.85 & 2.15 & 1.61 & 1.77 & 1.73 & 2.00 & 1.99 & 2.32 \\
\hline$\Sigma$ & 82.5 & 84.6 & 83.3 & 84.9 & 83.9 & 86.2 & 86.8 & 85.3 \\
\hline Si & 14.73 & 14.66 & 14.73 & 14.72 & 14.55 & 14.73 & 14.70 & 14.79 \\
\hline $\mathrm{Ti}$ & 0.00 & 0.00 & 0.00 & 0.00 & 0.01 & 0.01 & 0.00 & 0.00 \\
\hline A) & 3.34 & 3.35 & 3.31 & 3.33 & 3.47 & 3.31 & 3.36 & 3.25 \\
\hline${ }^{\Sigma}$ tet & 18.07 & 18.01 & 18.04 & 18.05 & 18.02 & 18.05 & 18.06 & 18.04 \\
\hline $\mathrm{Fe}$ & 0.01 & 0.03 & 0.02 & 0.02 & 0.10 & 0.03 & 0.03 & 0.05 \\
\hline $\mathrm{Ba}$ & 0.00 & 0.00 & 0.00 & 0.00 & 0.01 & 0.00 & 0.00 & 0.00 \\
\hline $\mathrm{Mg}$ & 0.00 & 0.01 & 0.00 & 0.01 & 0.01 & 0.00 & 0.01 & 0.00 \\
\hline $\mathrm{Ca}$ & 0.51 & 0.55 & 0.51 & 0.46 & 0.53 & 0.50 & 0.57 & 0.41 \\
\hline $\mathrm{Na}$ & 1.44 & 1.44 & 1.61 & 1.58 & 1.49 & 1.41 & 1.32 & 1.45 \\
\hline$x$ & 0.55 & 0.62 & 0.47 & 0.51 & 0.51 & 0.57 & 0.56 & 0.67 \\
\hline${ }^{E}$ lar e cations & 2.51 & 2.65 & 2.61 & 2.58 & 2.65 & 2.51 & 2.49 & 2.58 \\
\hline${ }^{\Sigma}$ cations & 20.58 & 20.66 & 20.65 & 20.63 & 20.67 & 20.56 & 20.55 & 20.62 \\
\hline
\end{tabular}




\section{TABLE A-I I (cont.)}

Prow Pass Member of the Crater Flat Tuff (cont.) (3192-ft, 973-m depth)

\begin{tabular}{lccc} 
& \multicolumn{3}{c}{ Mordenite in } \\
& Late & Radial & Fans \\
\cline { 2 - 4 } $\mathrm{SiO}_{2}$ & 67.3 & 68.5 & 67.6 \\
$\mathrm{TiO}_{2}$ & 0.00 & 0.00 & 0.00 \\
$\mathrm{Al}_{2} \mathrm{O}_{3}$ & 11.7 & 12.0 & 11.6 \\
$\mathrm{FeO}^{2}$ & 0.04 & 0.04 & 0.05 \\
$\mathrm{BaO}$ & 0.00 & 0.00 & 0.00 \\
$\mathrm{Mg0}$ & 0.00 & 0.00 & 0.00 \\
$\mathrm{CaO}$ & 1.60 & 1.27 & 1.37 \\
$\mathrm{Na}_{2}{ }^{0}$ & 4.59 & 4.99 & 4.30 \\
$\mathrm{~K}_{2} \mathrm{O}^{2}$ & 0.68 & 0.68 & 0.73 \\
$\Sigma$ & 85.4 & 87.5 & 85.7 \\
& & & \\
$\mathrm{Si}$ & 15.04 & 14.96 & 15.02 \\
$\mathrm{Ti}$ & 0.00 & 0.00 & 0.00 \\
$\mathrm{Al}$ & 2.94 & 3.08 & 3.05 \\
$\Sigma_{\text {tet }}$ & 17.98 & 18.04 & 18.07 \\
$\mathrm{Fe}$ & 0.00 & 0.00 & 0.01 \\
$\mathrm{Ba}$ & 0.00 & 0.00 & 0.00 \\
$\mathrm{Mg}$ & 0.00 & 0.00 & 0.00 \\
$\mathrm{Ca}$ & 0.38 & 0.29 & 0.32 \\
$\mathrm{Na}$ & 1.99 & 2.11 & 1.85 \\
$\mathrm{~K}$ & 0.19 & 0.19 & 0.20 \\
$\Sigma$ & 2.56 & 2.59 & 2.38 \\
$\Sigma_{\text {cations }}$ & 20.54 & 20.63 & 20.45
\end{tabular}


TABLE A-II (cont.)

Prow Pass member of the Crater Flat Tuff (cont.)

(3250-ft, or 991-m depth)

\begin{tabular}{|c|c|c|c|}
\hline \multirow[b]{2}{*}{$\mathrm{SiO}_{2}$} & \multicolumn{3}{|c|}{$\begin{array}{l}\text { Clinoptilolite in } \\
\text { Relict Shard Rims }\end{array}$} \\
\hline & 66.9 & 68.2 & 66.3 \\
\hline $\mathrm{TiO}_{2}$ & 0.00 & 0.00 & 0.00 \\
\hline $\mathrm{Al}_{2} \mathrm{O}_{3}$ & 11.6 & 12.0 & 11.7 \\
\hline $\mathrm{Fe} 0$ & 0.08 & 0.13 & 0.00 \\
\hline $\mathrm{Ba} 0$ & 0.02 & 0.04 & 0.07 \\
\hline $\mathrm{MgO}$ & 0.00 & 0.02 & 0.00 \\
\hline $\mathrm{CaO}$ & 2.33 & 2.37 & 2.51 \\
\hline $\mathrm{Na}_{2} \mathrm{O}$ & 3.73 & 4.20 & 3.01 \\
\hline $\mathrm{K}_{2} \mathrm{O}$ & 0.04 & 0.13 & 0.06 \\
\hline$\Sigma$ & 84.6 & 87.1 & 83.7 \\
\hline$S i$ & 15.00 & 14.92 & 15.03 \\
\hline $\mathrm{Tj}$ & 0.00 & 0.00 & 0.60 \\
\hline Al & 3.05 & 3.10 & 3.11 \\
\hline$\Sigma_{\text {tet }}$ & 18.05 & 18.02 & 18.14 \\
\hline $\mathrm{Fe}$ & 0.01 & 0.02 & 0.00 \\
\hline $\mathrm{Ba}$ & 0.00 & 0.00 & 0.00 \\
\hline $\mathrm{Mg}$ & 0.00 & 0.00 & 0.00 \\
\hline $\mathrm{Ca}$ & 0.56 & 0.55 & 0.60 \\
\hline $\mathrm{Na}$ & 1.62 & 1.78 & 1.32 \\
\hline K & 0.01 & 0.03 & 0.09 \\
\hline Elarge cations & 2.20 & 2.38 & 2.01 \\
\hline$\Sigma_{\text {cations }}$ & 20.25 & $20.4 \Gamma$ & 20.15 \\
\hline
\end{tabular}


TABLE A-I I (cont.)

Bullfrog Member of the Crater Flat Tuff

(3492-ft, 1064-m depth)

Clinoptilolite Crystal in Void Space

$\begin{array}{lccccccc}\mathrm{SiO}_{2} & 69.3 & 69.0 & 68.5 & 68.6 & 70.3 & 69.8 & 69.5 \\ \mathrm{TiO}_{2} & 0.04 & 0.00 & 0.00 & 0.00 & 0.04 & 0.03 & 0.05 \\ \mathrm{Al}_{2} \mathrm{O}_{3} & 12.5 & 12.5 & 12.2 & 12.4 & 12.5 & 12.8 & 12.6 \\ \mathrm{FeO} & 0.03 & 0.00 & 0.00 & 0.04 & 0.03 & 0.06 & 0.07 \\ \mathrm{BaO} & 0.00 & 0.00 & 0.00 & 0.00 & 0.00 & 0.00 & 0.06 \\ \mathrm{Mg0} & 0.00 & 0.00 & 0.00 & 0.00 & 0.00 & 0.00 & 0.00 \\ \mathrm{CaO} & 2.38 & 2.14 & 2.25 & 2.21 & 1.14 & 2.41 & 2.29 \\ \mathrm{Na}_{2} \mathrm{O} & 2.00 & 2.73 & 2.45 & 1.49 & 2.15 & 2.36 & 2.73 \\ \mathrm{~K}_{2} \mathrm{O} & 0.42 & 0.32 & 0.67 & 0.23 & 0.39 & 0.38 & 0.43 \\ \Sigma & 86.6 & 86.7 & 86.1 & 85.0 & 86.6 & 87.8 & 87.7 \\ & & & & & & & \\ \mathrm{Si} & 15.08 & 15.03 & 15.05 & 15.12 & 15.21 & 15.02 & 15.00 \\ \mathrm{Ti} & 0.00 & 0.00 & 0.00 & 0.00 & 0.00 & 0.00 & 0.00 \\ \mathrm{Al} & 3.20 & 3.20 & 3.15 & 3.23 & 3.18 & 3.23 & 3.21 \\ \Sigma_{\text {tet }} & 18.28 & 18.23 & 18.20 & 18.35 & 18.40 & 18.25 & 18.21 \\ \mathrm{Fe} & 0.00 & 0.00 & 0.00 & 0.00 & 0.00 & 0.00 & 0.01 \\ \mathrm{Ba} & 0.00 & 0.00 & 0.00 & 0.00 & 0.00 & 0.00 & 0.00 \\ \mathrm{Mg} & 0.00 & 0.00 & 0.00 & 0.00 & 0.00 & 0.00 & 0.00 \\ \mathrm{Ca} & 0.56 & 0.50 & 0.53 & 0.53 & 0.26 & 0.56 & 0.53 \\ \mathrm{Na} & 0.84 & 1.16 & 1.04 & 0.63 & 0.90 & 0.99 & 1.14 \\ \mathrm{~K} & 0.12 & 0.09 & 0.20 & 0.06 & 0.11 & 0.11 & 0.12 \\ \Sigma & 1.52 & 1.75 & 1.77 & 1.22 & 1.27 & 1.66 & 1.80 \\ \Sigma_{\text {large }} \text { cations } & 19.80 & 19.98 & 19.97 & 19.57 & 19.67 & 19.91 & 20.01 \\ & & & & & & & \end{array}$


TABLE A-III

ZEOLITE ANALYSES FROM DRILL HOLE UE25b-1H

Bullfrog Member of the Crater Flat Tuff

(2832-ft, 863-m depth)

Mg-Heulandite Crystals in Void Space

\begin{tabular}{|c|c|c|c|c|c|c|c|c|c|}
\hline $\mathrm{SiO}_{2}$ & 58.1 & 58.3 & 58.2 & 58.2 & 60.0 & 59.9 & 58.3 & 59.0 & 58.2 \\
\hline $\mathrm{Ti} \mathrm{O}_{2}$ & 0.00 & 0.00 & 0.00 & 0.00 & 0.00 & 0.00 & 0.00 & 0.00 & 0.00 \\
\hline $\mathrm{Al}_{2} \mathrm{O}_{3}$ & 16.5 & 16.2 & 15.8 & 15.8 & 17.0 & 16.5 & 16.2 & 16.0 & 16.2 \\
\hline $\mathrm{FeO}$ & 0.00 & 0.00 & 0.00 & 0.00 & 0.00 & 0.00 & 0.00 & 0.00 & 0.05 \\
\hline BaO & 0.00 & 0.00 & 0.03 & 0.00 & 0.18 & 0.00 & 0.00 & 0.11 & 0.08 \\
\hline $\mathrm{MgO}$ & 0.69 & 0.82 & 0.86 & 0.84 & 0.71 & 0.91 & 0.91 & 0.86 & 0.86 \\
\hline $\mathrm{CaO}$ & 5.79 & 5.93 & 5.79 & 5.86 & 4.89 & 6.06 & 5.91 & 5.70 & 5.75 \\
\hline $\mathrm{Na}_{2} \mathrm{O}$ & 0.59 & 0.70 & 0.76 & 0.67 & 1.91 & 0.23 & 0.36 & 0.74 & 0.72 \\
\hline $\mathrm{K}_{2} \mathrm{O}$ & 1.01 & 1.33 & 1.29 & 1.26 & 1.15 & 1.41 & 1.38 & 1.36 & 1.08 \\
\hline$\Sigma$ & 82.7 & 83.2 & 82.8 & 82.7 & 85.9 & 85.0 & 83.0 & 83.7 & 82.9 \\
\hline Si & 13.61 & 13.59 & 13.67 & 13.67 & 13.58 & 13.67 & 13.61 & 13.68 & 13.61 \\
\hline$T i$ & 0.00 & 0.00 & 0.00 & 0.00 & 0.00 & 0.00 & 0.00 & 0.00 & 0.00 \\
\hline Al & 4.55 & 4.44 & 4.37 & 4.38 & 4.53 & 4.41 & 4.46 & 4.35 & 4.46 \\
\hline$\Sigma_{\text {tet }}$ & 18.16 & 18.03 & 18.04 & 18.05 & 18.11 & 18.08 & 18.07 & 18.03 & 18.07 \\
\hline $\mathrm{Fe}$ & 0.00 & 0.00 & 0.00 & 0.00 & 0.00 & 0.00 & 0.00 & 0.00 & 0.00 \\
\hline $\mathrm{Ba}$ & 0.00 & 0.00 & 0.00 & 0.00 & 0.02 & 0.00 & 0.00 & 0.01 & 0.00 \\
\hline Mg & 0.24 & 0.29 & 0.30 & 0.29 & 0.24 & 0.32 & 0.32 & 0.30 & 0.30 \\
\hline $\mathrm{Ca}$ & 1.46 & 1.50 & 1.46 & 1.47 & 1.19 & 1.50 & 1.47 & 1.41 & 1.44 \\
\hline $\mathrm{Na}$ & 0.26 & 0.30 & 0.35 & 0.30 & 0.84 & 0.09 & 0.16 & 0.33 & 0.33 \\
\hline K & 0.30 & 0.39 & 0.39 & 0.38 & 0.33 & 0.41 & 0.41 & 0.41 & 0.41 \\
\hline${ }^{\Sigma}$ large cations & 2.26 & 2.48 & 2.50 & 2.44 & 2.62 & 2.32 & 2.36 & 2.46 & 2.48 \\
\hline$\Sigma_{\text {cations }}$ & 20.42 & 20.51 & 20.54 & 20.49 & 20.73 & 20.40 & 20.43 & 20.49 & 20.55 \\
\hline
\end{tabular}


TABLE A-IV $V^{\mathrm{a}}$

\section{CLAY ANALYSES FROM DRILL HOLE USH-G2}

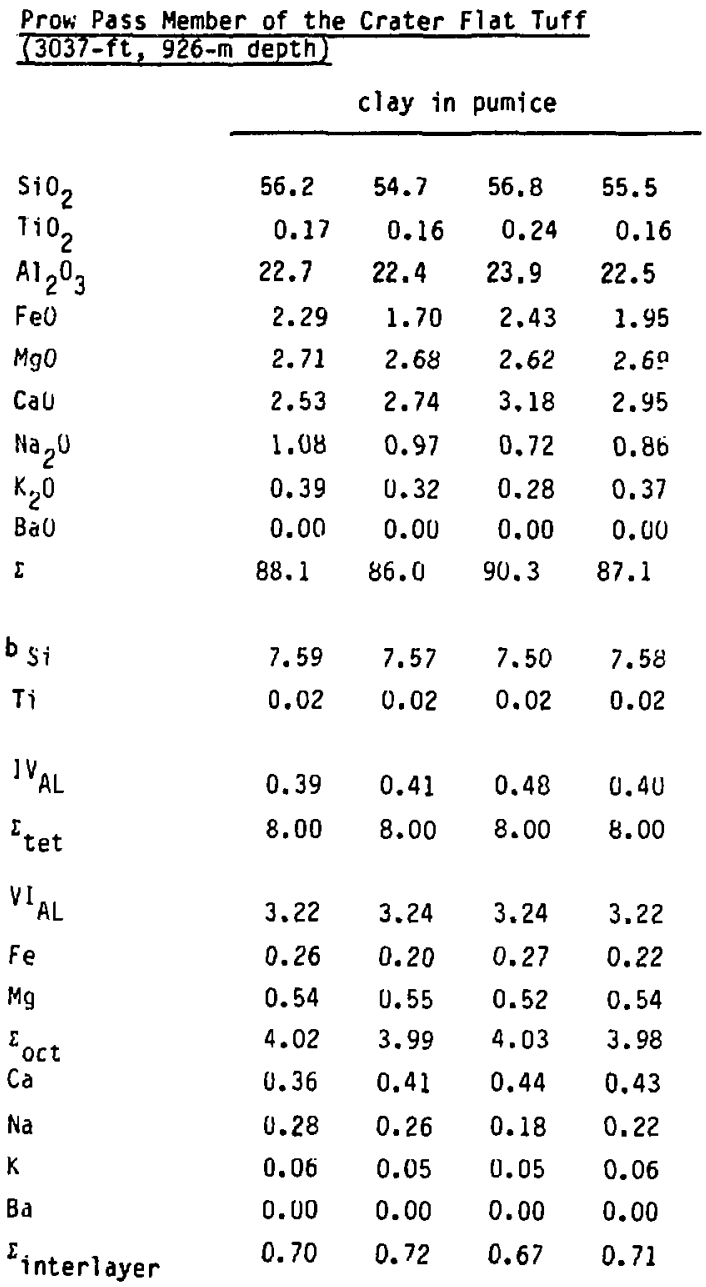

\footnotetext{
Under the high-vacuum and heating effects of electron microprobe analysis, the weight percent total analyses of most cleys should total between 90\% and 95\%. Many of the clays listed in tables A-IV and A-Y have lower totals that ref lect the analysis of fine-grained minerals in an epoxy-impregnated thin section: the low totals may result from the adnixture of epoxy with clay, but the analysis ts reported if the formula stoichionetry is correct. Stoichiometric calculations are based on 20-oxygen, 4-OH (or 22 oxygen equivalent) formula. . On this basis, the tetrahedral site occuoancy is assumed to be eight. With dioctahedral site occupancy 4.00 and total between 0.7 and 1.7 for interlayer

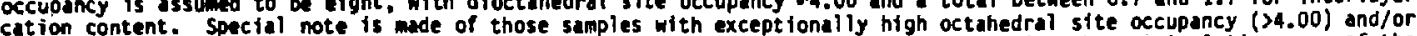
low interlayer cation content $(<0.67)$; in' these samples stoichiometry might be maintained by recalculating some of the Ma as anterlayer rather than as an octahedrally co-ordinated cation (Mg can occur as an exchangeable cation in many simetite clays).
}

batton compositions are based on normalization to 22 oxygens. 
TABLE A-IV (cont.)

Prow Pass Member of the Crater Flat Tuff (cont.)

(3250-ft, 991-m depth)

clay in pumice

\begin{tabular}{|c|c|c|c|c|c|c|}
\hline $\mathrm{SiO}_{2}$ & 55.5 & 55.6 & 56.9 & 56.8 & 57.0 & 55.2 \\
\hline $\mathrm{TiO}_{2}$ & 0.33 & 0.20 & 0.16 & 0.16 & 0.19 & 0.05 \\
\hline $\mathrm{Al}_{2} \mathrm{O}_{2}$ & 20.1 & 21.1 & 20.8 & 20.5 & 20.9 & 21.6 \\
\hline FeO & 5.97 & 7.5 & 7.6 & 7.5 & 7.3 & 7.1 \\
\hline MgO & 1.52 & 1.57 & 1.50 & 1.52 & 1.53 & 1.68 \\
\hline $\mathrm{CaO}$ & 0.86 & 1.48 & 1.87 & 1.66 & 1.69 & 1.29 \\
\hline $\mathrm{Na}_{2} \mathrm{O}$ & 0.77 & 1.45 & 1.09 & 1.68 & 1.23 & 1.66 \\
\hline $\mathrm{K}_{2} \mathrm{O}$ & 2.90 & 1.58 & 1.37 & 1.11 & 1.32 & 1.01 \\
\hline $\mathrm{BaO}$ & 0.11 & 0.00 & 0.07 & 0.00 & 0.00 & 0.00 \\
\hline$\Sigma$ & 88.2 & 90.7 & 91.3 & 90.9 & 91.2 & 89.6 \\
\hline b Si & 7.72 & 7.57 & 7.67 & 7.67 & 7.67 & $7.5 b$ \\
\hline Ti & 0.03 & 0.02 & 0.02 & 0.02 & 0.02 & 0.00 \\
\hline${ }^{J}{ }_{A L}$ & 0.25 & 0.41 & 0.31 & 0.3 & 0.31 & 0.45 \\
\hline$\Sigma_{\text {tet }}$ & 8.00 & 8.00 & 8.00 & 8.00 & 8.00 & 8.00 \\
\hline$V_{\mathrm{AL}}$ & 3.05 & 2.97 & 2.99 & 2.95 & 3.00 & 3.02 \\
\hline $\mathrm{Fe}$ & 0.69 & 0.86 & 0.85 & 0.84 & 0.82 & 0.81 \\
\hline $\mathrm{Mg}$ & 0.31 & 0.31 & 0.30 & 0.30 & 0.30 & 0.34 \\
\hline$\Sigma_{\text {oct }}$ & 4.05 & 4.14 & 4.14 & 4.09 & 4.12 & 4.17 \\
\hline $\mathrm{CA}$ & 0.13 & 0.21 & 0.27 & 0.24 & 0.24 & 0.19 \\
\hline NA & 0.20 & 0.38 & 0.29 & 0.44 & 0.32 & 0.44 \\
\hline K & 0.51 & 0.27 & 0.23 & 0.19 & 0.22 & 0.17 \\
\hline$B A$ & 0.00 & 0.00 & 0.00 & 0.00 & 0.00 & 0.00 \\
\hline$\Sigma_{\text {interlayer }}$ & 0.84 & 0.86 & 0.79 & 0.87 & 0.78 & 0.80 \\
\hline
\end{tabular}




\section{TABLE A-IV $\mathrm{v}^{\mathrm{a}}$ (cont.)}

Bullfrog Meriber of the Crater Flat Tuff

\begin{tabular}{cc}
$\begin{array}{c}\text { (3492-ft, } 1065-m \text { depth) } \\
\text { clay in pumice }\end{array}$ & $\begin{array}{c}354 l-f t, 1080-m \text { depth }) \\
\text { clay in pumice }\end{array}$ \\
\hline
\end{tabular}

$\mathrm{TiO}_{2}$

$\mathrm{N}_{2} \mathrm{O}_{3}$

$\mathrm{FeO}$

$\mathrm{MgO}$

$\mathrm{CaO}$

$\mathrm{Na}_{2} \mathrm{O}$

$\mathrm{K}_{2} \mathrm{O}$

$\mathrm{BaO}$

$\Sigma$

53.9

55.5

51.4

0.04

0.16

0.15

22.5

22.2

20.4

5.88

5.86

6.34

$1.62 \quad 1.61$

1.91

1.23

1.25

0.57

0.23

0.20

0.45

1.72

1.99

4.95

0.08

0.03

0.00

87.3

88.9

86.3

Si

Ti

7.52

7.60

7.46

0.00

0.02

0.01

$I V_{A L}$

0.48

0.38

0.53

$\varepsilon_{\text {tet }}$

8.00

8.00

8.00

$V I_{A L}$

3.21

3.20

2.96

$\mathrm{Fe}$

0.68

0.67

0.77

$\mathrm{Mg}$

Eoct

0.33

0.32

0.41

$4.22^{\mathrm{C}}$

$4.19^{\mathrm{C}}$

4.14

$\mathrm{Ca}$

0.18

0.18

0.09

Na

0.06

0.05

0.12

K

0.30

0.35

0.92

$\mathrm{Ba}$

0.00

0.00

0.00

Iinterlayer

$0.54^{c}$

$0.58^{c}$

1.13

c Magnesium may occur as an interlayer cation; this would lower the sum of octahedrally co-ordinated cations to 4 and raise the interlayer cation content to 0.7 in these samples. 


\section{TABLE A-IV ${ }^{\mathrm{a}}$ (cont.)}

Iram Member of the Crater Flat Tuff

(3875-ft, 1182-m depth)

Kalkberg clay in pumice

$\mathrm{SiO}_{2}$

$\mathrm{TiO}_{2}$

$\mathrm{Al}_{2} \mathrm{O}_{3}$

$\mathrm{FeO}$

$\mathrm{HgO}$

$\mathrm{CaO}$

$\mathrm{Na}_{2} \mathrm{O}$

$\mathrm{K}_{2} \mathrm{O}$

Ba 0

$\Sigma$

Si

Ti

I $V_{\mathrm{AL}}$

Loct

$V I_{A L}$

$\mathrm{Fe}$

$\mathrm{Mg}$

Eoct

$\mathrm{Ca}$

Na

K

$\mathrm{Ba}$

Iinterlayer
48.5

0.00

25.0

3.36

1.35

0.19

0.13

5.97

0.00

84.5

7.10

0.00

0.90

8.00

3.42

0.41

0.29

4.12

0.02

0.03

1.11

0.00

1.16
46.7

0.00

24.5

3.20

1.24

0.26

0.20

6.88

0.00

83.0

7.03

0.00

0.97

8.00

3.38

0.40

0.28

4.06

0.04

0.06

1.32

0.00

1.42
Tram Member of the Crater Flat Tuff (cont.)

(3933-ft, 1200-m depth)

clay in matrix

$\mathrm{SiO}_{2}$

$\mathrm{TiO}_{2}$

$\mathrm{Al}_{2} \mathrm{O}_{3}$

$\mathrm{FeO}$

$\mathrm{MgU}$

$\mathrm{CaO}$

$\mathrm{Ha}_{2} \mathrm{O}$

$\mathrm{K}_{2} \mathrm{O}$

$\mathrm{BaO}$

$\Sigma$

48.6

0.34

19.3

8.5

1.36

0.23

0.20

6.81

0.07

85.5

Si

7.32

$\mathrm{Ti}$

0.04

IV $\mathrm{AL}$

0.64

Eoct

8.00

$V_{\text {AL }}$

2.79

$\mathrm{Fe}$

1.07

Mg

0.31

soct

4.17

0.04

$\mathrm{Ca}$

0.06

$k$

1.31

$\mathrm{Ba}$

0.00

Einterlayer

1.41 
Rhyodacite Lava

(4090-ft, 1247-m depth)

\begin{tabular}{|c|c|c|c|c|c|}
\hline \multirow[b]{2}{*}{$\mathrm{SiO}_{2}$} & \multicolumn{5}{|c|}{ blue clay in matrix } \\
\hline & 54.5 & 53.1 & 54.6 & 58.7 & 54.2 \\
\hline $\mathrm{TiO}_{2}^{2}$ & 0.00 & 0.00 & 0.00 & 0.00 & 0.00 \\
\hline $\mathrm{Al}_{2} \mathrm{O}_{3}^{2}$ & 18.5 & 18.3 & 18.4 & 18.9 & 17.4 \\
\hline $\mathrm{FeO}$ & 1.01 & 0.94 & 0.91 & 1.19 & 1.01 \\
\hline $\mathrm{MgO}$ & 3.73 & 3.61 & 3.62 & 4.18 & 4.04 \\
\hline $\mathrm{CaO}$ & 1.49 & 1.29 & 1.09 & 1.05 & 1.06 \\
\hline $\mathrm{Na}_{2} \mathrm{O}$ & 0.14 & 0.25 & 0.29 & 0.21 & 0.22 \\
\hline $\mathrm{K}_{2} \mathrm{O}$ & 2.09 & 2.31 & 2.24 & 2.47 & 2.21 \\
\hline $\mathrm{BaO}$ & 0.00 & 0.00 & 0.00 & 0.00 & 0.00 \\
\hline$\varepsilon$ & $81.5^{\star}$ & $79.8^{*}$ & $81.3^{\star}$ & 86.8 & $80.3^{\star}$ \\
\hline Si & 7.79 & 7.91 & 7.95 & 8.02 & 8.01 \\
\hline $\mathrm{Ti}$ & 0.00 & 0.00 & 0.00 & 0.00 & 0.00 \\
\hline$I V_{A L}$ & 0.07 & 0.09 & 0.05 & 0.00 & 0.00 \\
\hline$\Sigma_{\text {tet }}$ & 8.00 & 8.00 & 8.00 & 8.02 & 8.01 \\
\hline $\mathrm{VI}_{\mathrm{AL}}$ & 3.10 & 3.11 & 3.12 & 3.05 & 3.03 \\
\hline Fe & 0.12 & 0.11 & 0.11 & 0.13 & 0.12 \\
\hline $\mathrm{Mg}$ & 0.81 & 0.80 & 0.78 & 0.85 & 0.89 \\
\hline$\Sigma_{\text {oct }}$ & 4.03 & 4.52 & 4.01 & 4.03 & 4.04 \\
\hline $\mathrm{Ca}$ & 0.23 & 0.20 & 0.17 & 0.15 & 0.16 \\
\hline $\mathrm{Na}$ & 0.04 & 0.07 & 0.08 & 0.05 & 0.06 \\
\hline$k$ & 0.38 & 0.44 & 0.41 & 0.43 & 0.42 \\
\hline $\mathrm{Ba}$ & 0.00 & 0.00 & 0.00 & 0.00 & 0.00 \\
\hline$\Sigma_{\text {interlaver }}$ & 0.65 & 0.71 & 0.66 & 0.63 & 0.64 \\
\hline
\end{tabular}

Bedded Tuff above the Lithic Ridge Tuff (4199-ft, 1281-m depth)

clay in vein

$\mathrm{SiO}_{2}$

$\mathrm{TiO}_{2}$

$\mathrm{Al}_{2} \mathrm{O}_{3}$

$\mathrm{FeU}$

$\mathrm{MgO}$

52.8

0.98

20.3

6.23

3.31

$\mathrm{CaO}$

0.47

$\mathrm{Na}_{2} \mathrm{O}$

0.08

$\mathrm{K}_{2} \mathrm{O}$

7.16

$\mathrm{BaO}$

0.00

$\Sigma$

91.3

si

7.33

$\mathrm{Ti}$

0.10

I $V_{\text {AL }}$

0.57

$\Sigma_{\text {tet }}$

8.00

$\mathrm{VI}_{\mathrm{AL}}$

2.75

$\mathrm{Fe}$

0.72

$\mathrm{Ng}$

0.68

$\Sigma_{\text {oct }}$

4.15

$\mathrm{Ca}$

0.07

$\mathrm{Na}$

0.02

$\mathrm{K}$

1.27

Ba

0.00

Einterlayer

1.36 


\section{TABLE A-IV ${ }^{a}$ (cont.)}

Lithic Ridge Tuff

(4467-ft, 1362-m depth)

Kalkberg-type illite-smectite clay in pumice

$\begin{array}{lcccccc}\mathrm{SIO}_{2} & 52.6 & 53.6 & 54.0 & 53.8 & 52.6 & 53.2 \\ \mathrm{TiO}_{2} & 0.04 & 0.04 & 0.05 & 0.11 & 0.03 & 0.09 \\ \mathrm{Al}_{2} \mathrm{O}_{3} & 27.4 & 28.2 & 28.4 & 25.7 & 26.8 & 26.2 \\ \mathrm{FeO}_{\mathrm{MgO}} & 2.61 & 2.50 & 2.35 & 3.49 & 2.71 & 3.30 \\ \mathrm{CaO} & 2.30 & 2.14 & 2.12 & 2.79 & 2.48 & 2.56 \\ \mathrm{Na}_{2} \mathrm{O} & 0.20 & 0.31 & 0.23 & 0.16 & 0.21 & 0.16 \\ \mathrm{~K}_{2} 0 & 0.41 & 0.47 & 0.52 & 0.40 & 0.44 & 0.40 \\ \mathrm{BaO} & 8.65 & 8.61 & 8.42 & 8.29 & 8.05 & 8.31 \\ \varepsilon & 0.00 & 0.00 & 0.00 & 0.00 & 0.00 & 0.00 \\ & 94.3 & 95.9 & 96.1 & 94.8 & 93.3 & 94.3 \\ \mathrm{Si} & & & & & & \\ \mathrm{Ti} & 7.00 & 6.99 & 7.00 & 7.12 & 7.04 & 7.07\end{array}$

IV $\mathrm{AL}$

$\begin{array}{llllll}1.00 & 1.01 & 1.00 & 0.87 & 0.96 & 0.92\end{array}$

$\Sigma$ tet

8.00

8.00

8.00

8.00

8.00

$\mathrm{VI}_{\mathrm{AL}}$

$\mathrm{Fe}$

$\mathrm{Mg}$

E oct

Ca

$\mathrm{Na}$

K

3.2

3.31

3.34

3.14

3.26

3.19

0.29

0.27

0.25

0.38

0.30

0.37

0.45

0.41

0.41

0.55

0.50

0.51

4.03

3.99

4.00

4.07

4.06

4.07

0.03

0.04

0.03

0.02

0.03

0.02

0.10

0.12

0.13

0.10

0.1

0.10

1.4

1.43

1.39

1.40

1.38

1.41

Ba

0.00

0.00

0.00

0.00

0.00

0.00

${ }^{E}$ interlayer

1.60

1.59

1.55

1. 52

1. 52

1.53 
TABLE A-IV (cont.)

Quartz Latite Lava

(5293-ft, 1614-m depth)

clay in feldspar

$\begin{array}{lr}\mathrm{SiO}_{2} & 50.7 \\ \mathrm{TiO}_{2} & 0.07 \\ \mathrm{Al}_{2} \mathrm{U}_{3} & 29.5 \\ \mathrm{FeO} & 2.65 \\ \mathrm{MgO} & 2.00 \\ \mathrm{CaO} & 0.46 \\ \mathrm{Na}_{2} \mathrm{O} & 0.14 \\ \mathrm{~K}_{2} \mathrm{O} & 6.91 \\ \mathrm{BaO} & 0.00 \\ \Sigma & 92.4\end{array}$

Si

6.81

Ti

0.00

IV $\mathrm{AL}$

1.19

$\Sigma_{\text {tet }}$

8.00

$V I_{A L}$

3.47

$\mathrm{Fe}$

0.30

Mg

0.40

Eoct

4.17

$\mathrm{Ca}$

0.06

$\mathrm{Na}$

0.04

I

1.18

$\mathrm{Ba}$

0.00

interlayer

1.28 
TABLE A-IV (cont.)

Ash Flow

(5657-ft, 1725-m depth)

\begin{tabular}{|c|c|c|c|c|c|}
\hline \multirow[b]{2}{*}{$\mathrm{SiO}_{2}$} & \multicolumn{3}{|c|}{ Illite crystal } & \multirow{2}{*}{$\frac{\begin{array}{l}\text { clay in } \\
\text { pumice }\end{array}}{48.4}$} & \multirow{2}{*}{$\begin{array}{l}\begin{array}{c}\text { void } \\
\text { filling } \\
\text { clay }\end{array} \\
51.0\end{array}$} \\
\hline & 47.7 & 48.6 & 49.2 & & \\
\hline $\mathrm{TiO}_{2}$ & 0.30 & 1.50 & 0.30 & 0.14 & 0.13 \\
\hline $\mathrm{Al}_{2} \mathrm{U}_{3}$ & 27.6 & 26.8 & 26.7 & 27.9 & 24.9 \\
\hline $\mathrm{FeO}$ & 3.27 & 2.72 & 3.52 & 2.66 & 3.48 \\
\hline $\mathrm{MgO}$ & 2.74 & 1.94 & 2.47 & 2.12 & 2.80 \\
\hline $\mathrm{CaO}$ & 0.06 & 0.02 & 0.01 & 0.32 & 0.04 \\
\hline $\mathrm{Na}_{2} \mathrm{O}$ & 0.09 & 0.00 & 0.05 & 0.08 & 0.14 \\
\hline $\mathrm{K}_{2} 0$ & 9.23 & 9.66 & 9.50 & 8.44 & 7.95 \\
\hline $\mathrm{Ba} 0$ & 0.13 & 0.17 & 0.20 & 0.00 & 0.00 \\
\hline$\Sigma$ & 91.1 & 91.4 & 92.0 & 90.0 & 90.6 \\
\hline $5 i$ & 6.66 & 6.76 & 6.81 & 6.75 & 7.06 \\
\hline $\mathrm{Ti}$ & 0.03 & 0.16 & 0.03 & 0.14 & 0.13 \\
\hline$I V_{A L}$ & 1.31 & 1.08 & 1.16 & 1.11 & 0.81 \\
\hline$\Sigma_{\text {tet }}$ & 8.00 & 8.00 & 8.00 & 8.00 & 8.00 \\
\hline$V I_{A L}$ & 3.23 & 3.31 & 3.20 & 3.48 & 3.25 \\
\hline $\mathrm{Fe}$ & 0.38 & 0.31 & 0.41 & 0.31 & 0.40 \\
\hline $\mathrm{Mg}$ & 0.57 & 0.40 & 0.51 & 0.44 & 0.58 \\
\hline$\varepsilon_{\text {oct }}$ & 4.18 & 4.02 & 4.12 & $4.23^{c}$ & $4.23^{c}$ \\
\hline $\mathrm{Ca}$ & 0.01 & 0.00 & 0.00 & 0.00 & 0.04 \\
\hline $\mathrm{Na}$ & 0.02 & 0.00 & 0.01 & 0.02 & 0.04 \\
\hline$k$ & 1.64 & 1.71 & 1.68 & 1.50 & 1.40 \\
\hline $\mathrm{Ba}$ & 0.00 & 0.01 & 0.01 & 0.00 & 0.00 \\
\hline$\varepsilon_{\text {interlayer }}$ & 1.67 & 1.72 & 1.70 & $1.52^{c}$ & $2.48^{c}$ \\
\hline
\end{tabular}

c Magnesium may occur as an interlayer cation. 


\section{TABLE A-IV (cont.)}

Reworked Tuff

(5895-ft, 1800-m depth)

\begin{tabular}{|c|c|c|c|c|}
\hline \multirow[b]{2}{*}{$\mathrm{SiO}_{2}$} & \multicolumn{2}{|c|}{ clay in pumice } & \multicolumn{2}{|c|}{ clay crystal } \\
\hline & 51.3 & 52.9 & 52.4 & 52.7 \\
\hline $\mathrm{TiO}_{2}^{2}$ & 0.14 & 0.10 & 0.21 & 0.20 \\
\hline $\mathrm{Al}_{2} \mathrm{O}_{3}$ & 27.2 & 24.8 & 19.6 & 19.2 \\
\hline $\mathrm{FeO}$ & 3.43 & 2.93 & 9.4 & 9.4 \\
\hline $\mathrm{MgO}$ & 1.98 & 1.65 & 2.63 & 2.64 \\
\hline $\mathrm{CaO}$ & 0.29 & 0.56 & 0.27 & 0.32 \\
\hline $\mathrm{Na}_{2} \mathrm{O}$ & 0.24 & 0.45 & 0.20 & 0.17 \\
\hline $\mathrm{K}_{2} \mathrm{O}$ & 8.78 & 8.27 & 8.76 & 8.87 \\
\hline BaO & 0.00 & 0.00 & 0.08 & 0.00 \\
\hline$\Sigma$ & 93.3 & 91.6 & 93.5 & 93.5 \\
\hline si & 6.93 & 7.23 & 7.31 & 7.35 \\
\hline $\mathrm{Ti}$ & 0.01 & 0.01 & 0.02 & 0.02 \\
\hline$I V_{A L}$ & 1.06 & 0.76 & 0.67 & 0.63 \\
\hline$\Sigma_{\text {tet }}$ & 8.00 & 8.00 & 8.00 & 8.00 \\
\hline$V I_{A L}$ & 3.27 & 3.24 & 2.55 & 2.52 \\
\hline $\mathrm{Fe}$ & 0.38 & 0.33 & 1.09 & 1.10 \\
\hline $\mathrm{Mg}$ & 0.40 & 0.33 & 0.54 & 0.54 \\
\hline$\Sigma_{\text {oct }}$ & 4.05 & 3.90 & 4.18 & 4.16 \\
\hline $\mathrm{Ca}$ & 0.04 & 0.08 & 0.04 & 0.04 \\
\hline $\mathrm{Na}$ & 0.06 & 0.12 & 0.05 & 0.04 \\
\hline$k$ & 1.51 & 1.44 & 1.55 & 1.57 \\
\hline $\mathrm{Ba}$ & 0.00 & 0.00 & 0.00 & 0.00 \\
\hline$\Sigma_{\text {interlayer }}$ & 1.61 & 1.64 & 1.64 & 1.65 \\
\hline
\end{tabular}




\section{TABLE A-IV (cont.)}

\section{Older Ash Flow}

(5992-ft, 1828-m depth)

\begin{tabular}{|c|c|c|c|}
\hline \multirow[b]{2}{*}{$\mathrm{SiO}_{2}$} & \multicolumn{3}{|c|}{ clay in pumice } \\
\hline & 52.4 & 51.5 & 52.3 \\
\hline $\mathrm{TiO}_{2}^{2}$ & 0.24 & 0.14 & 0.20 \\
\hline $\mathrm{Al}_{2} \mathrm{O}_{3}$ & 27.0 & 27.2 & 26.7 \\
\hline $\mathrm{FeO}^{\circ}$ & 4.73 & 4.39 & 4.96 \\
\hline $\mathrm{MgO}$ & 1.90 & 1.76 & 1.81 \\
\hline $\mathrm{CaO}$ & 0.23 & 0.17 & 0.23 \\
\hline $\mathrm{Na}_{2} \mathrm{O}$ & 0.34 & 0.30 & 0.35 \\
\hline $\mathrm{K}_{2} \mathrm{O}$ & 8.57 & 8.83 & 8.79 \\
\hline $8 \mathrm{a} 0$ & 0.03 & 0.03 & 0.00 \\
\hline$\varepsilon$ & 95.4 & 94.3 & 95.3 \\
\hline Si & 6.96 & 6.91 & 6.97 \\
\hline $\mathrm{Ti}$ & 0.02 & 0.01 & 0.02 \\
\hline$I_{V A L}$ & 1.02 & 1.08 & 1.01 \\
\hline$\Sigma_{\text {tet }}$ & 8.00 & 8.00 & 8.00 \\
\hline $\mathrm{VI}_{\mathrm{AL}}$ & 3.20 & 3.23 & 3.17 \\
\hline $\mathrm{Fe}$ & 0.52 & 0.49 & 0.55 \\
\hline $\mathrm{Mg}$ & 0.37 & 0.35 & 0.36 \\
\hline$\Sigma_{\text {oct }}$ & 4.09 & 4.07 & 4.08 \\
\hline $\mathrm{Ca}$ & 0.03 & 0.02 & 0.03 \\
\hline $\mathrm{Na}$ & 0.08 & 0.08 & 0.09 \\
\hline K & 1.45 & 1.51 & 1.49 \\
\hline $\mathrm{Ba}$ & 0.00 & 0.00 & 0.00 \\
\hline$\Sigma_{\text {interlayer }}$ & 1.56 & 1.61 & 1.61 \\
\hline
\end{tabular}




\section{TABLE $A-V^{2}$}

\section{CLAY ANALYSES FROM DRILL HOLE UE25b-1H}

Bul lfrog Member of the Crater Flat Tuff (2855-ft, 871-m depth)
Tram Member of the Crater Flat Tuff (3326-ft, 1014-m depth)

clay in matrix

\begin{tabular}{|c|c|c|c|}
\hline $\mathrm{SiO}_{2}$ & 52.2 & 54.6 & 49.8 \\
\hline $\mathrm{TiO}_{2}$ & 0.17 & 0.67 & 0.29 \\
\hline $\mathrm{Al}_{2} \mathrm{O}_{3}$ & 20.3 & 18.2 & 18.8 \\
\hline $\mathrm{FeO}$ & 7.7 & 6.36 & 5.19 \\
\hline $\mathrm{MgO}$ & 3.10 & 2.14 & 4.44 \\
\hline $\mathrm{CaO}$ & 1.65 & 0.27 & 0.77 \\
\hline $\mathrm{Na}_{2} \mathrm{O}$ & 0.28 & 0.42 & 0.22 \\
\hline $\mathrm{K}_{2} \mathrm{O}$ & 4.63 & 6.82 & 6.29 \\
\hline $\mathrm{BaO}$ & 0.00 & 0.18 & .0 .04 \\
\hline$\Sigma$ & 90.2 & 90.1 & 86.1 \\
\hline Si & 7.32 & 7.68 & 7.32 \\
\hline $\mathrm{Ti}$ & 0.02 & 0.07 & 0.03 \\
\hline $\mathrm{IV}_{\mathrm{AL}}$ & 0.66 & 0.25 & 0.65 \\
\hline$\Sigma_{\text {tet }}$ & 8.00 & 8.00 & 8.00 \\
\hline${ }^{I} V_{A L}$ & 2.69 & 2.76 & 2.61 \\
\hline $\mathrm{Fe}$ & 0.90 & 0.75 & 0.63 \\
\hline $\mathrm{Mg}$ & 0.65 & 0.45 & 0.97 \\
\hline$\Sigma_{\text {oct }}$ & $4.24^{b}$ & 3.96 & $4.21^{b}$ \\
\hline $\mathrm{Ca}$ & 0.25 & 0.04 & 0.12 \\
\hline $\mathrm{Na}$ & 0.07 & 0.12 & 0.06 \\
\hline$K$ & 0.83 & 1.22 & 1.18 \\
\hline$B a$ & 0.00 & 0.01 & 0.00 \\
\hline$\dot{\Sigma}_{\text {interlayer }}$ & $1.15^{b}$ & 1.39 & $1.36^{\mathrm{b}}$ \\
\hline
\end{tabular}

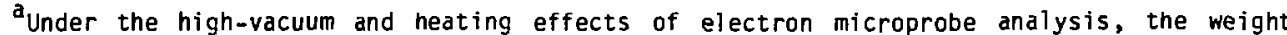
percent total analyses of most clays should total between $90 \%$ and $95 \%$. Many of the clays listed in tables $A-I V$ and $A-V$ have lower totals that reflect the analysis of fine-grained minerals in an epoxy-impregnated thin section: the low totals may result from the admixture of epoxy with clay, but the analysis is reported if the formula stoichiometry is correct. Stoichiometric calculations are based on a 20-oxygen, 4-OH (or 22 oxygen equivalent) formula. On this basis, the tetrahedral site occupancy is assumed to be eight, with dioctahedral site occupancy $\backsim 4.00$ and a total between 0.7 and 1.7 for interlayer cation content. Special note is made of those samples with exceptionally high octahedral site occupancy $(>4.00)$ and/or low interlayer cation content $(<0.67)$; in these samples stoichiometry might be maintained by recalculating some of the $\mathrm{Mg}$ as an interlayer rather than as an octahedrally co-ordinated cation (Mg can occur as an exchangeable cation in many smectite clays).

${ }^{b}$ Magnesium may occur as on interlayer cation. 
TABLE A-V (cont.)

Tram Member of the Crater Flat Tuff

(3326-ft, 1014-m depth)

$$
\text { clay in matrix }
$$

$\mathrm{SiO}_{2}$

$\mathrm{TiO}_{2}$

$\mathrm{Al}_{2} \mathrm{O}_{3}$

49.8

0.29

$\mathrm{FeO}$

18.8

Mg0

5.19

4.44

$\mathrm{CaU}$

0.77

$\mathrm{Na}_{2} \mathrm{O}$

0.22

$\mathrm{K}_{2} \mathrm{O}$

6.29

$\mathrm{Ba} 0$

0.04

I

86.1

Si

7.32

$\mathrm{Ti}$

0.03

IV $\mathrm{AL}$

0.65

$\Sigma_{\text {tet }}$

8.00

$V_{A L}$

2.61

$\mathrm{Fe}$

0.63

$\mathrm{Mg}$

0.97

$\Sigma_{\text {oct }}$

$4.21 \mathrm{~b}$

$\mathrm{Ca}$

0.12

$\mathrm{Na}$

0.06

K

1.18

$\mathrm{Ba}$

0.00

$\Sigma_{\text {interlayer }}$

$1.36^{b}$

b Magnesium may occur as an interlayer cation. 


\section{APPENDIX B}

\section{SCANNING ELECTRON MICROSCOPY OF AUTHIGENIC MINERAL PHASES}

Scanning electron microscopy was used to supplement $x$-ray diffraction, optical petrography, and electron probe microanalysis of mineral phases in core samples from USW-G2 and UE25b-1H. The SEM is an ISI model DS-130, and is equipped with a Kevex model $7000 x$-ray analysis system. Quantitative analysis is not possible on unpolished samples, but qualitative $x$-ray analyses were conducted to determine mineral phases when identification by morphology alone was questionable. The presence of some minerals, especially mordenite, was revealed occasionally when their abundances were below the detection limits of $x$-ray diffraction. The large surface area/volume ratio of mordenite, because of its fine-grained morphology, may make this mineral important for adsorption of radionuclides. Figures B-1 through B-8 are typical photomicrographs.

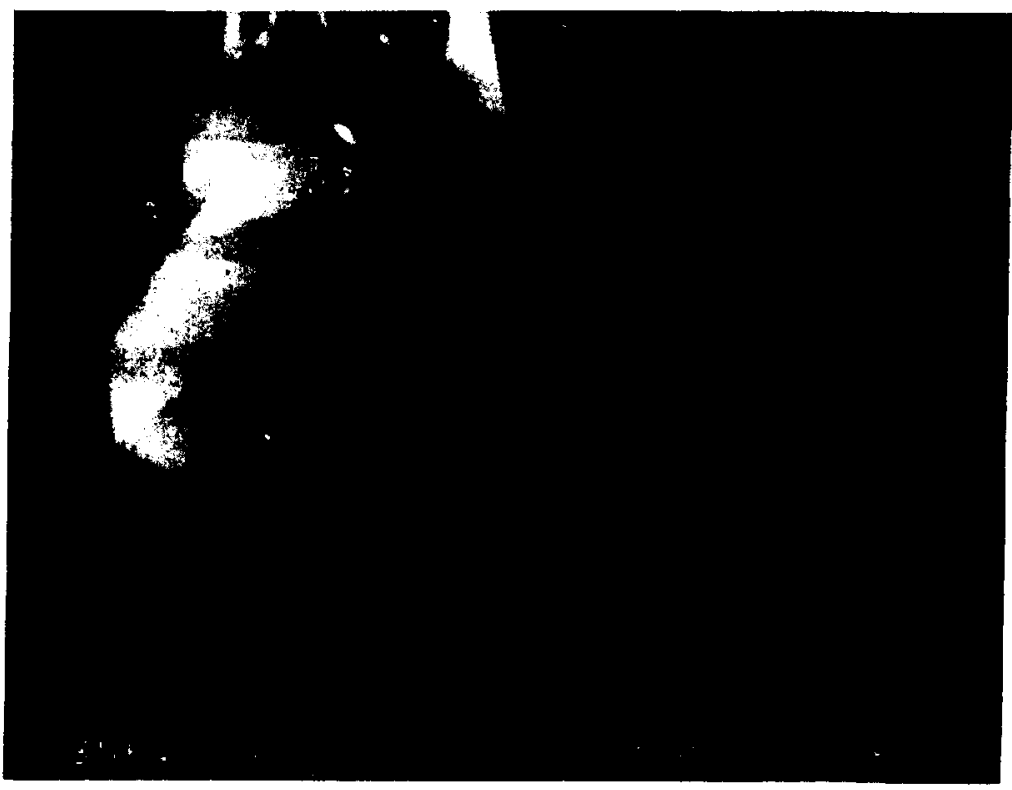

Fig. B-1.

Scanning electron micrograph of heulandite and mordenite in sample USW-G2 675. Heulandite is large blocky aggregate of crystals, while mordenite appears as acircular crystals. Light and dark zones on main heulandite are shadowing effects. Bar line is $5 \mathrm{\mu m}$. 


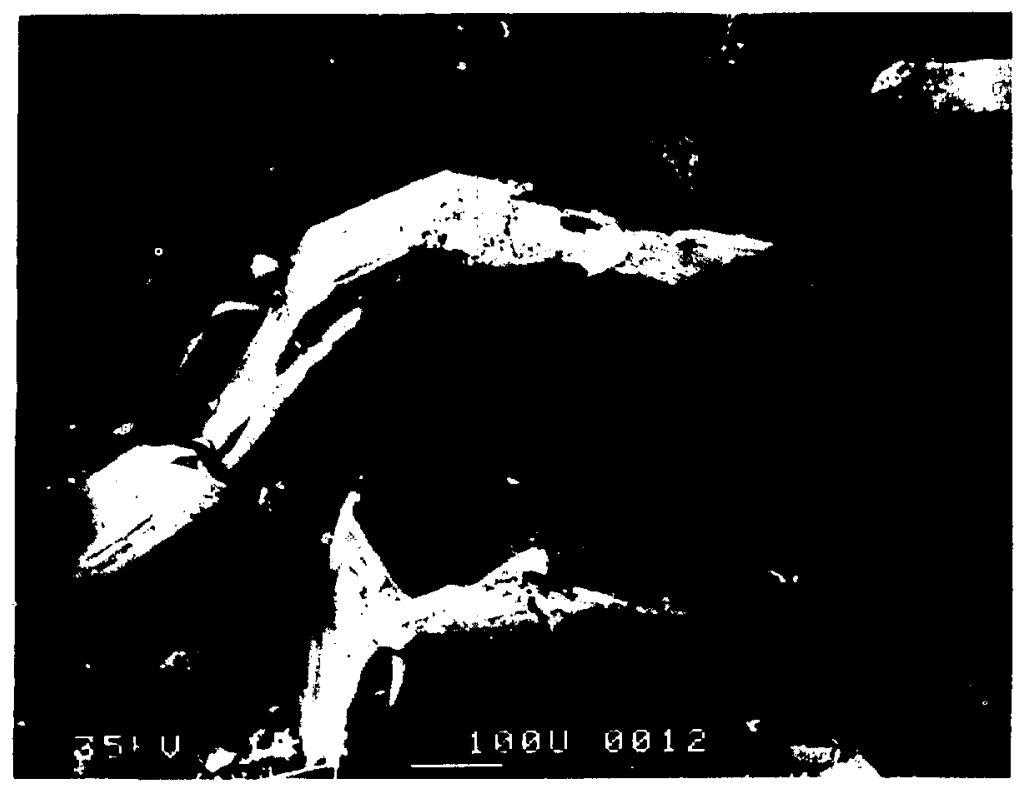

Fig. B-2.

Scanning electron micrograph of quartz after tridymite in vapor phase pocket. Sample USW-G2 1133. Bar line is $100 \mu \mathrm{m}$.

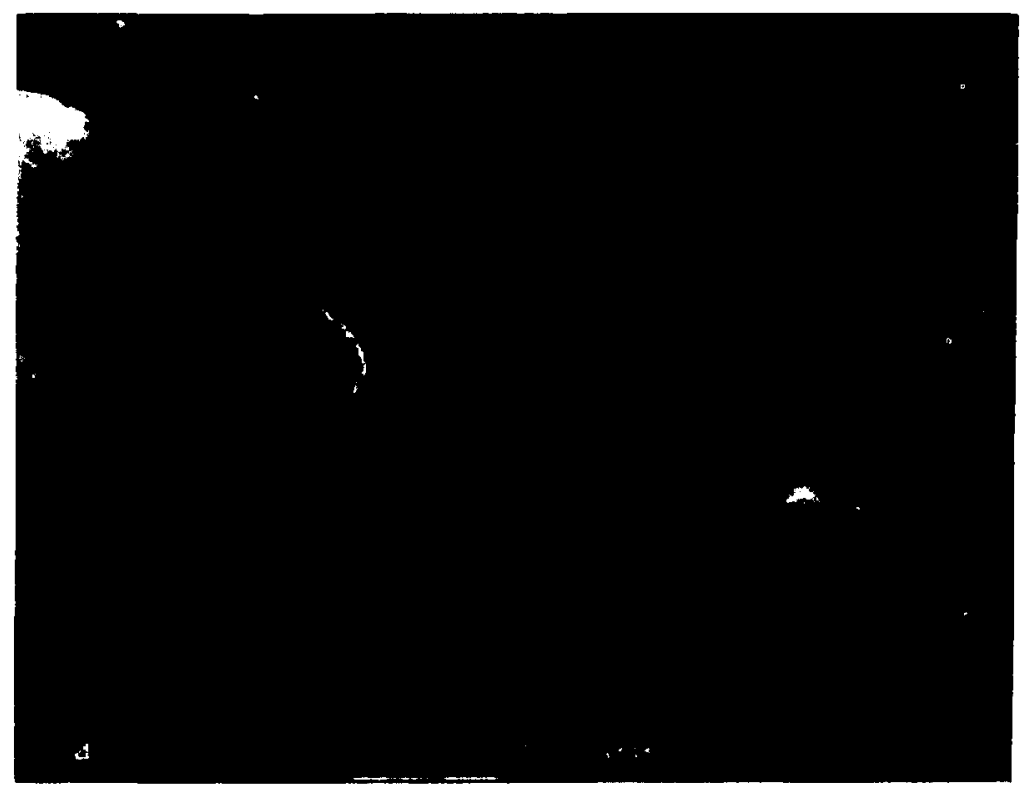

Fig. B-3.

Scanning electron micrograph of the zeolite clinoptilolite, in turn overgrown by a later generation of mordenite. Once again, clinoptilolite has a blocky morphology and mordenite is the fibrous growth. Sample USW-G2 1234. Bar line is $5 \mathrm{\mu m}$. 


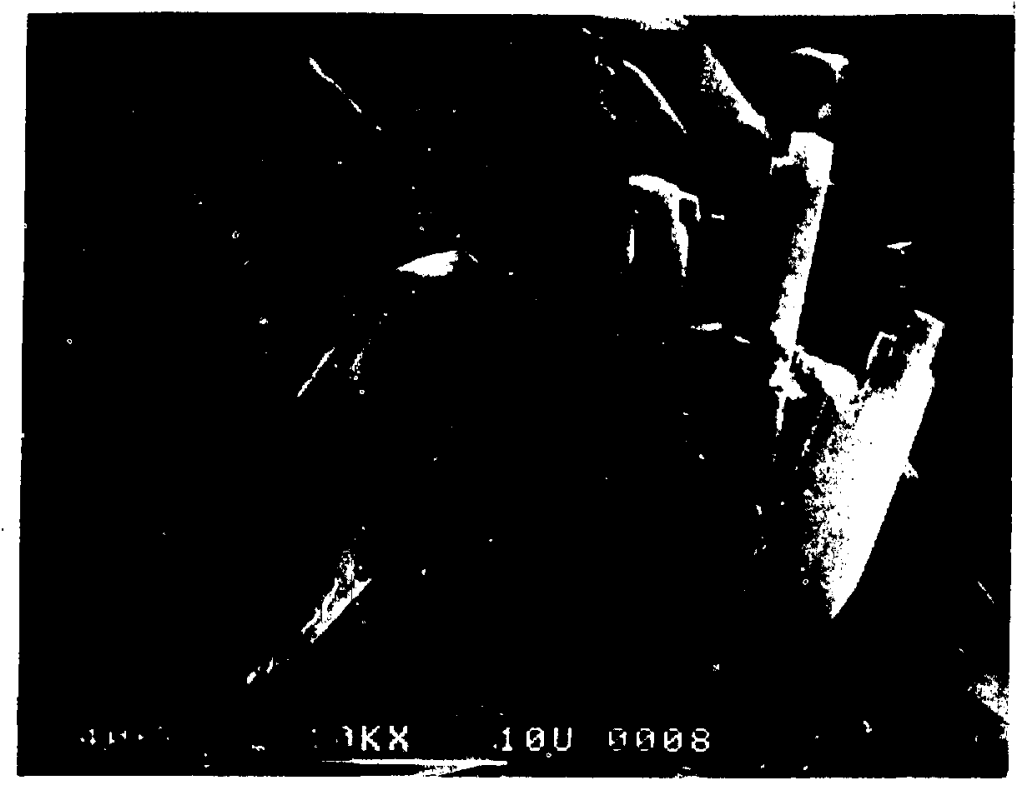

Fig. B-4.

Scanning electron micrograph of a cluster of clinoptilolite crystals. Sample USH-G2 1952. Bar line is $10 \mu \mathrm{m}$.

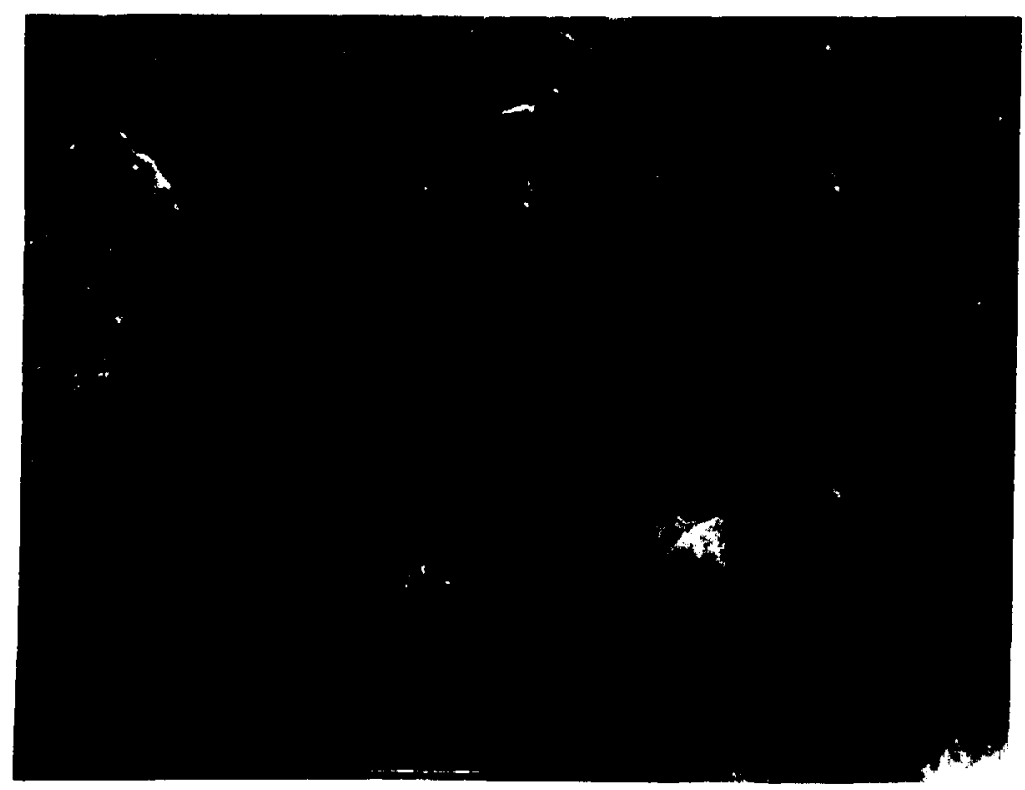

Fig. B-5.

Scanning electron micrograph of authigenic clays in the Bullfrog Member of the Crater Flat tuff. Sample USW-G2 3541. Bar line $10 \mu \mathrm{m}$. 


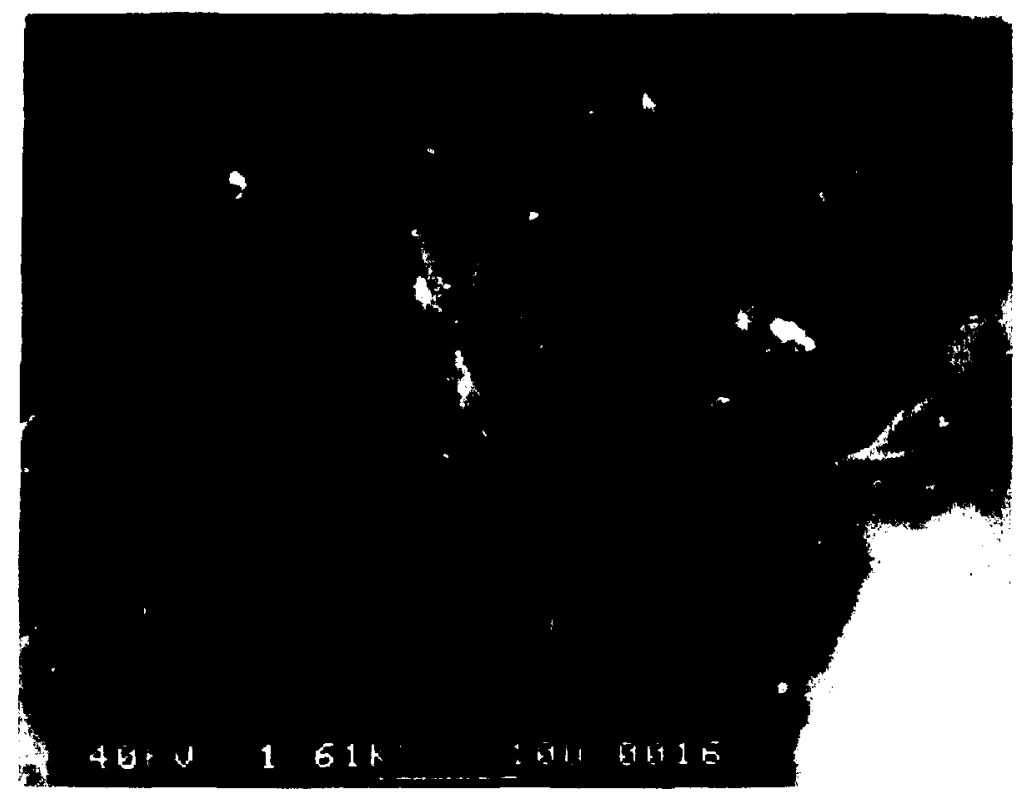

Fig. B-6.

Scanning electron micrograph of authigenic quartz and clays from bedded tuff above the Lithic Ridge Tuff. Sequence of growth is quartz and then clays. Sample USW-G2 4167. Bar line is $10 \mu \mathrm{m}$.

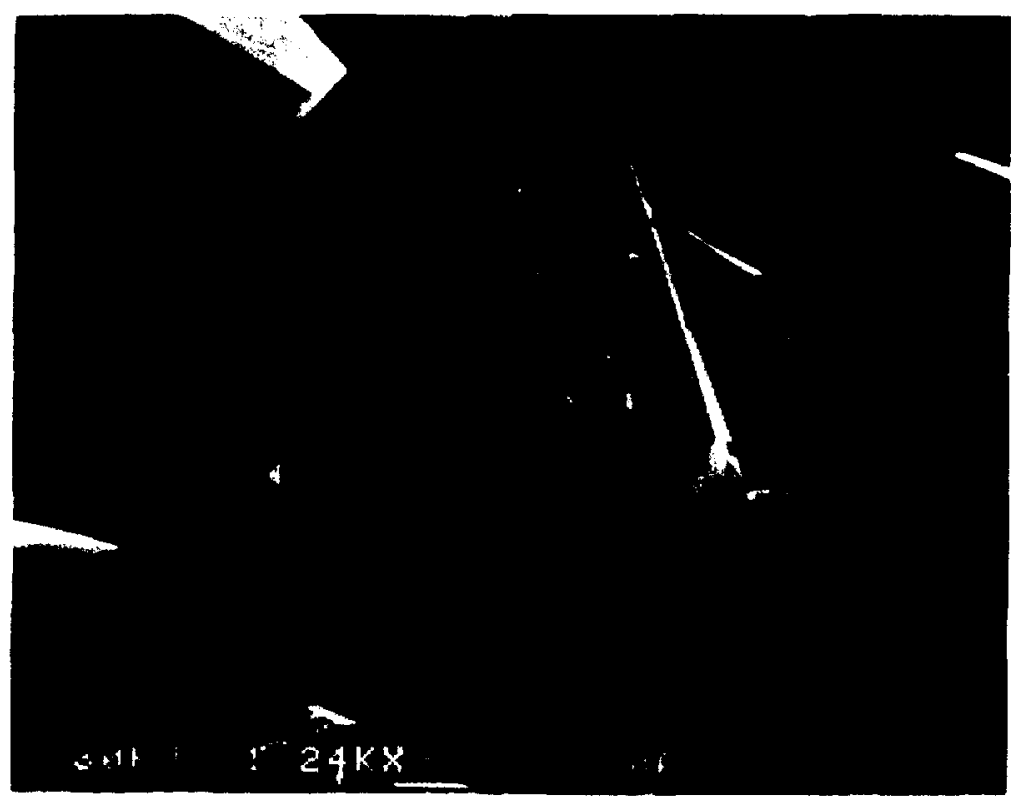

Fig. B-7.

Scanning electron micrograph of authigenic quartz from the rhyolite lava of USW-G2. Sample depth is $5017 \mathrm{ft}$. Bar line is $10 \mu \mathrm{m}$. 

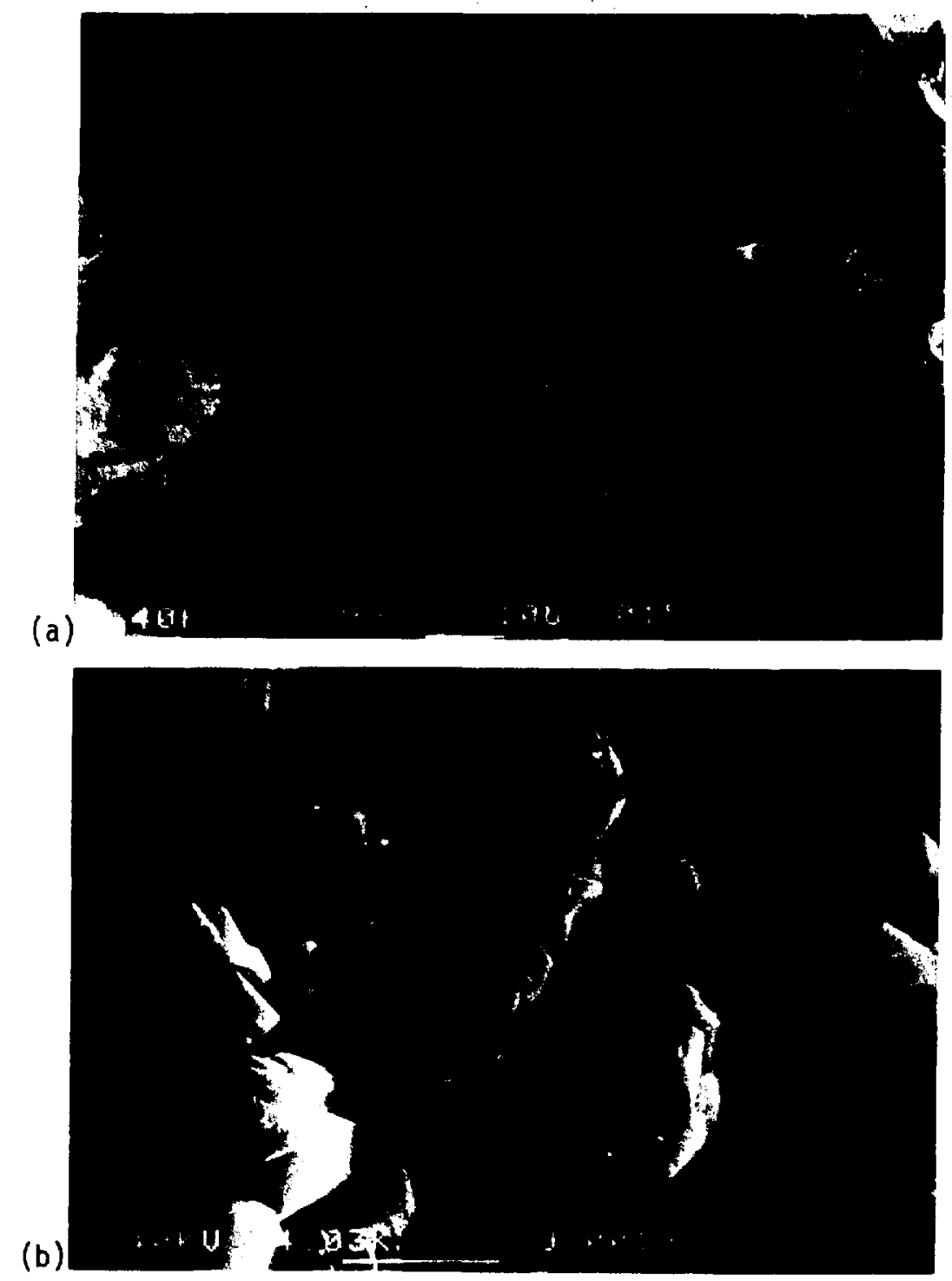

Fig. B-8.

Series of four scanning electron micrographs from a single zeolitized sample in the Lower Tram subunit of UE25b-1H drill core. Figures $A$ and $B$ are of clinoptilolite, Fig. C and D are of mordenite. Sample depth is $3708 \mathrm{ft}$ (1339 m).

(a) Clinoptilolite crystals lining and bridging vug. Minor wisps of mordenite can be seen as epitaxial growth on clinoptilolite. Bar line is $10 \mathrm{~mm}$.

(b) Clinoptilolite crystals coating surface on sample of UE25B-1 3708. Note partial dissolution of clinoptilolite along preferred orientations. The best example is seen in the extreme upper left hand corner. Bar line is 5 um.

(c) Radiating sprays of mordenite crystals. Bar line is $5 \mu \mathrm{m}$.

(d) Radiating spray of mordenite crystals. Enilargement of photomicrograph C. Bar line is $1 \mu \mathrm{m}$. 


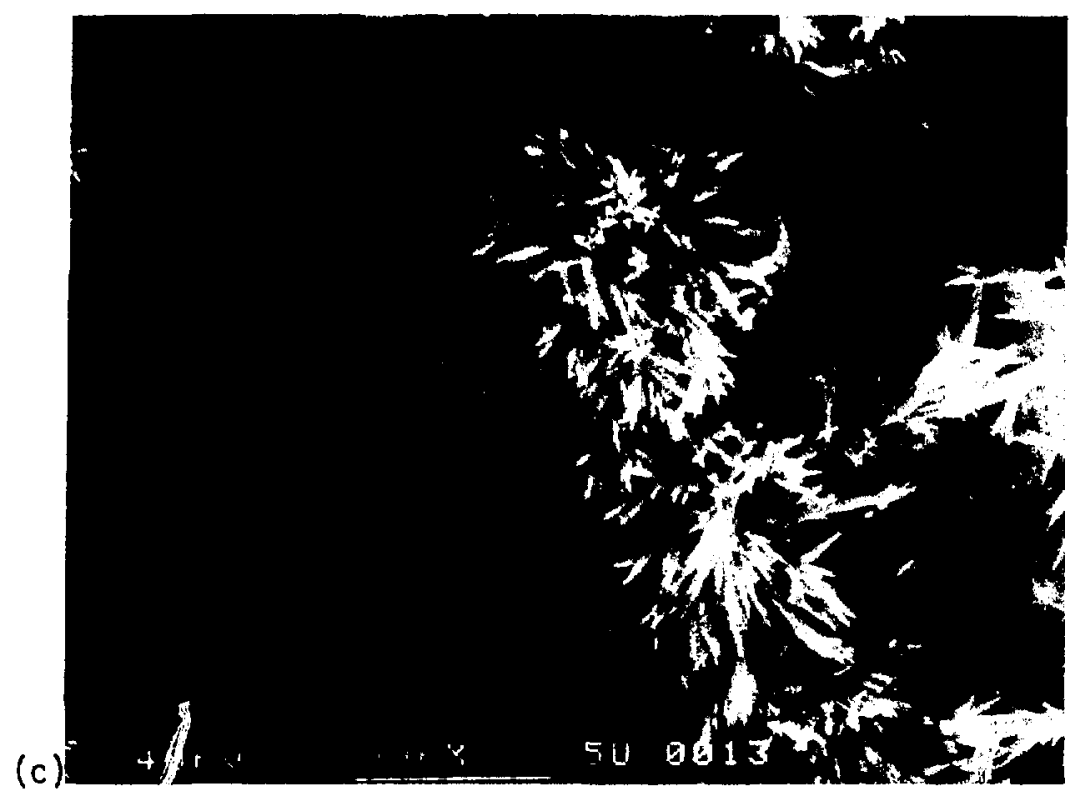

(d) 
Printed in the United States of America Available from

National Technical Information Service

US Department of Commerce

5285 Port Royal Road

Springfield. VA 22161

Microfiche (AOI)

NTIS

Page Range Price Code

$001.025 \quad A 02$

026.050

051.075

076.100

101.125

126150
$\mathrm{A02}$

A03

A04

A0s

A06

A07
NTIS

\begin{tabular}{cc} 
Page Range & Price Code \\
\hline 151.175 & A08 \\
176.200 & A09 \\
201.225 & A 10 \\
226.250 & A 11 \\
251.275 & A12 \\
276.300 & A13
\end{tabular}

NTIS

Price Code

\begin{tabular}{cc} 
Page Range & Price Code \\
\hline 301.325 & A 14 \\
326.350 & A 15 \\
351.375 & A 16 \\
376.400 & A 17 \\
401.425 & A 18 \\
426.450 & A 19
\end{tabular}

NTIS

\begin{tabular}{cc} 
Page Range & $\begin{array}{c}\text { NTIS } \\
\text { Price Code }\end{array}$ \\
\hline 451.475 & A20 \\
476.500 & A21 \\
501.525 & A22 \\
526.550 & A23 \\
551.575 & A24 \\
576.600 & A25 \\
$601.40^{\circ}$ & A99
\end{tabular}

"Contuat NTIS for a price quote. 


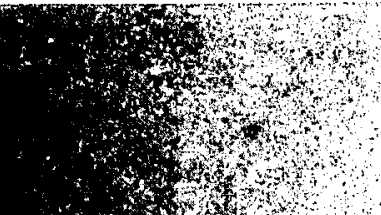

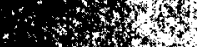

$\checkmark$

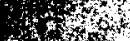

\%ol

340

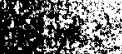
$+46$

$-5$

$\mathrm{S}^{2} \mathrm{n}$ $-4 x^{2} \mathrm{n}$,

4,8

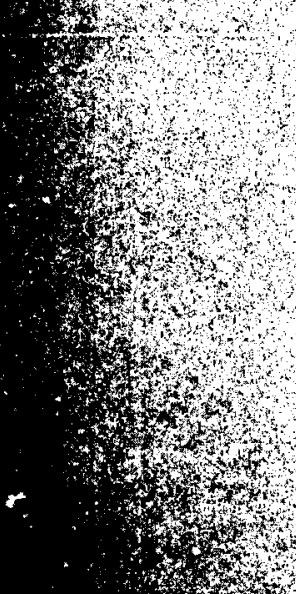

? 